University of New Hampshire

University of New Hampshire Scholars' Repository

Doctoral Dissertations

Student Scholarship

Winter 1995

\title{
Characterization of supported molybdenum sulfide catalyst ex ammonium tetrathiomolybdate
}

Fan Zhang

University of New Hampshire, Durham

Follow this and additional works at: https://scholars.unh.edu/dissertation

\section{Recommended Citation}

Zhang, Fan, "Characterization of supported molybdenum sulfide catalyst ex ammonium tetrathiomolybdate" (1995). Doctoral Dissertations. 1881.

https://scholars.unh.edu/dissertation/1881

This Dissertation is brought to you for free and open access by the Student Scholarship at University of New Hampshire Scholars' Repository. It has been accepted for inclusion in Doctoral Dissertations by an authorized administrator of University of New Hampshire Scholars' Repository. For more information, please contact Scholarly.Communication@unh.edu. 


\section{INFORMATION TO USERS}

This manuscript has been reproduced from the microfilm master. UMI films the text directly from the original or copy submitted. Thus, some thesis and dissertation copies are in typewriter face, while others may be from any type of computer printer.

The quality of this reproduction is dependent upon the quality of the copy submitted. Broken or indistinct print, colored or poor quality illustrations and photographs, print bleedthrough, substandard margins, and improper alignment can adversely affect reproduction.

In the unlikely event that the author did not send UMI a complete manuscript and there are missing pages, these will be noted. Also, if unauthorized copyright material had to be removed, a note will indicate the deletion.

Oversize materials (e.g., maps, drawings, charts) are reproduced by sectioning the original, beginning at the upper left-hand corner and continuing from left to right in equal sections with small overlaps. Each original is also photographed in one exposure and is included in reduced form at the back of the book.

Photographs included in the original manuscript have been reproduced xerographically in this copy. Higher quality 6 " $\times 9$ " black and white photographic prints are available for any photographs or illustrations appearing in this copy for an additional charge. Contact UMI directly to order.

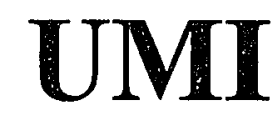

A Bell \& Howell Information Company 300 North Zeeb Road, Ann Arbor MI 48106-1346 USA

$313 / 761-4700 \quad 800 / 521-0600$ 
Reproduced with permission of the copyright owner. Further reproduction prohibited without permission. 


\title{
CHARACTERIZATION OF SUPPORTED MOLYBDENUM SULFIDE CATALYST EX AMMONIUM TETRATHIOMOLYBDATE
}

\author{
BY \\ Fan Zhang \\ B.S., Tsinghua University (P.R. China), 1984 \\ M.S., Tsinghua University (P.R. China), 1987 \\ Dissertation \\ Submitted to the University of New Hampshire \\ in Partial Fulfillment of \\ the Requirements for the Degree of \\ Doctor of Philosophy \\ in \\ Engineering
}

December, 1995 
UMI Number: 9617080

\section{Copyright 1996 by \\ Zhang, Fan}

All rights reserved.

UMI Microform 9617080

Copyright 1996, by UMI Company. All rights reserved.

This microform edition is protected against unauthorized copying under Title 17, United States Code.

\section{UMI \\ 300 North Zeeb Road \\ Ann Arbor, MI 48103}


This dissertation has been examined and approved.

$$
\text { P.T.Vandiven. }
$$

Dissertation Director, Dr. Palligarnai T. Vasudevan

Associate Professor of Chemical Engineering

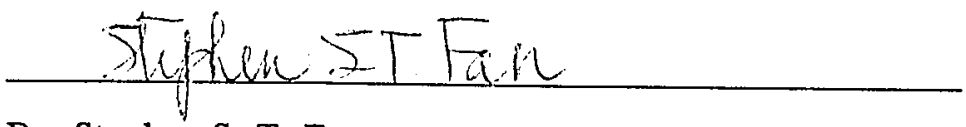

Dr. Stephen S. T. Fan

Professor of Chemical Engineering

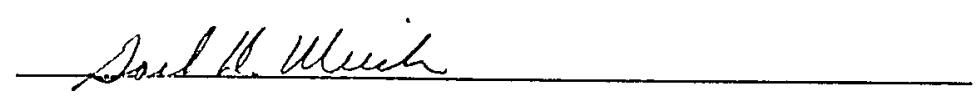

Dr. Gael D. Ulrich

Professor of Chemical Engineering

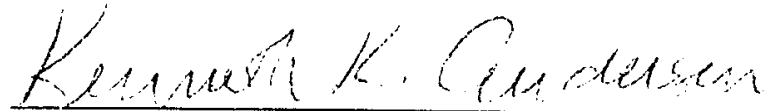

Dr. Kenneth K. Andersen

Professor of Chemistry

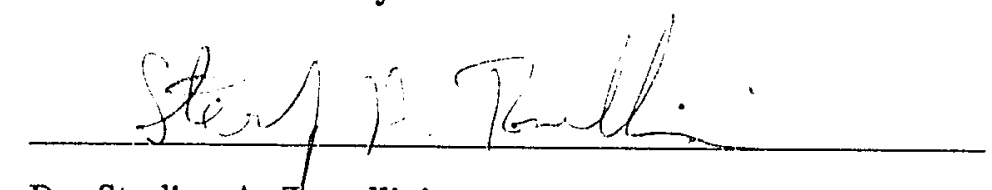

Dr. Sterling A. Tomellini

Associate Professor of Chemistry

Sepatember 29,1995




\section{DEDICATION}

To my parents, husband and son 


\section{ACKNOWLEDGEMENTS}

The author would like to take this opportunity to express her sincere gratitude and thankfulness to her advisor Dr. Vasudevan for his continuous encouragement, professional guidance, and patient assistance in directing the research of this dissertation.

The author acknowledges Dr. Fan, Dr. Ulrich, Dr. Andersen and Dr. Tomellini for serving on the dissertation committee and for their valuable suggestions.

The author would like to express her appreciation to Mr. Jonathan E. Newell for his help during this work. The author would like to thank Dr. Tomellini for his assistance in the IR spectroscopic measurements.

The author would like to give special thanks to her husband, Chunming, her son, Shengyang, and her sister, Bing, for their love, encouragement and support during these years.

Financial support of this work by the National Science Foundation under Grant No. CTS9109845 is gratefully acknowledged.

iv 


\section{TABLE OF CONTENTS}

Dedication

Acknowledgements

iv

List of Tables

viii

List of Figures

ix

Abstract

xiii

1 INTRODUCTION 1

2 LITERATURE REVIEW 5

2.1 General Properties of Sulfide Catalysts . . . . . . . . . . . . 5

2.2 Unsupported Molybdenum Catalyst from ATTM . . . . . . . . 6

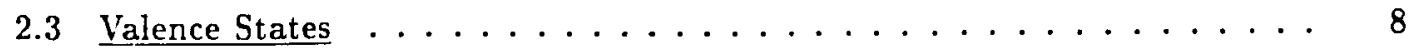

2.4 Active Sites and LTOC ................... 10

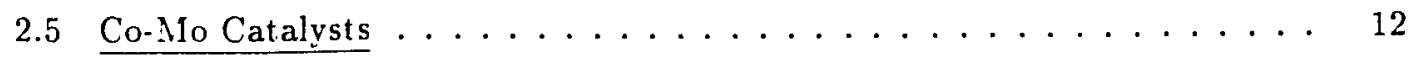

3 EXPERIMENTAL 14

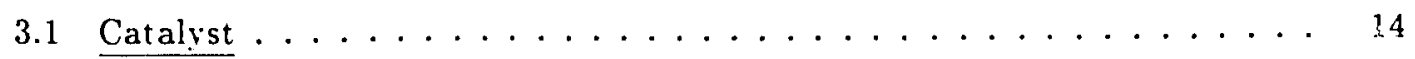

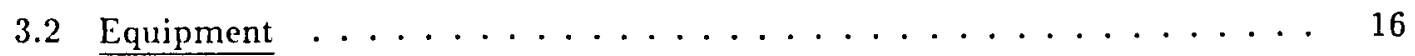

3.3 Experimental Procedure . . . . . . . . . . . . . . 16

3.3 .1 Pretreatment ........................ 16

3.3 .2 Pulse Adsorption Measurement $\ldots \ldots \ldots \ldots$

3.3.3 Temperature-Programmed Desorption (TPD) .......... 18

3.3 .4 BET Measurement $\ldots \ldots \ldots \ldots \ldots$

V 


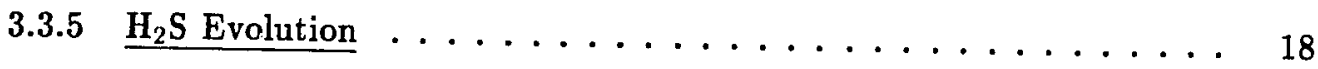

3.3.6 Measurement of Catalyst Activity ............. 19

\section{RESULTS AND DISCUSSION}

4.1 Preparation of Catalyst $\ldots \ldots \ldots \ldots 21$

4.2 Effect of Pretreatment on LTOC, BET Area and TPR $\ldots \ldots \ldots 21$

4.2 .1 Analysis of TPR Data .................. 22

4.2.2 Effect of Reduction Temperature .............. 23

4.2.3 Effect of Sample Size ................... 26

4.3 Correlation of Pretreatment, LTOC and Activity . . . . . . . . . . 27

4.3.1 Thiophene Hydrogenolysis ................. 28

4.3 .2 Propylene Hydrogenation $\ldots \ldots \ldots \ldots . \ldots . \ldots 47$

4.4 Temperature-Programmed Desorption .............. 56

4.5 Cobalt-Promoted Molybdenum Catalyst .............. 65

4.5.1 Temperature-Programmed Reduction ............ 65

4.5.2 Effect of Cobalt on the Activity of $\mathrm{Mo} / \mathrm{Al}_{2} \mathrm{O}_{3} \ldots \ldots \ldots$

4.6 Catalyst Stability ................... 76

5 CONCLUSIONS AND RECOMMENDATIONS 81

5.1 Conclusions ......................... 81

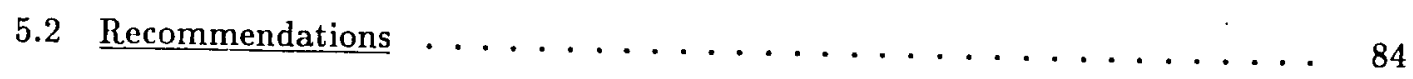

$\begin{array}{lr}\text { Bibliography } & 86\end{array}$

A LOW TEMPERATURE OXYGEN CHEMISORPTION 90

B BET AREA MEASUREMENT

C HYDROGEN SULFIDE EVOLUTION

D PRODUCT COMPOSITION MEASUREMENT

vi 
F RAW DATA 


\section{LIST OF TABLES}

4.1 Molybdenum Content ..................... 22

4.2 Effect of Reduction Temperature . . . . . . . . . . . . . 26

4.3 Effect of Sample Size . . . . . . . . . . . . . . . . 27

4.4 Effect of Pretreatment on Thiophene Conversion and LTOC $\ldots \ldots$. . . 31

4.5 Effect of Reductive Sulfiding on Catalyst Activity . . . . . . . . . . . 32

4.6 Effect of Catalyst Preparation on Thiophene Conversion . . . . . . . 36

4.7 Comparison of Pulse and Continuous Method-Effect of Pretreatment . . . . 37

4.8 Comparison of Pulse and Continuous Method-Effect of Catalyst Preparation 42

4.9 Effect of Pretreatment on $\mathrm{H}_{2} \mathrm{~S}$ Concentration . . . . . . . . . . . 44

4.10 Effect of $\mathrm{H}_{2} \mathrm{~S}$ Concentration on Thiophene Conversion . . . . . . . . 46

4.11 Temperature-Programmed Desorption of $\mathrm{H}_{2} \mathrm{~S} \ldots \ldots \ldots$

4.12 The Comparison of Co-promoted and Unpromoted ATTM $/ \mathrm{Al}_{2} \mathrm{O}_{3} \ldots \ldots$

4.13 ATtM Stability Study . . . . . . . . . . . . . . . . 80

A.1 A Sample Calculation for LTOC ................. 91

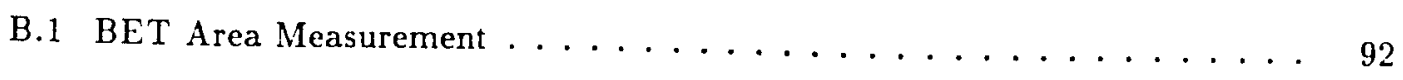

D.1 Thiophene Conversion ................... 99

F.1 Propylene Activity After 1st Regeneration, Calibration counts = 901304 . 145

F.2 Propylene Activity After 2nd Regeneration, Calibration counts $=965730 \quad$ • 145

F.3 A comparison to Run $9-10 \ldots \ldots \ldots \ldots \ldots \ldots$. . . . . . . . . . . . .

viii 


\section{LIST OF FIGURES}

2.1 Crystal structure of hexagonal $\mathrm{MoS}_{2}$, - - Mo atom, o - S atom [Vukasovich,

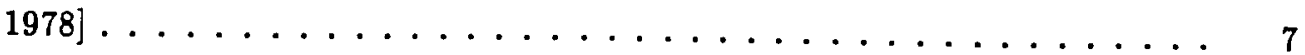

3.1 Schematic of Apparatus ................... 17

4.1 Temperature-programmed reduction profile for $\mathrm{MoS}_{y} / \mathrm{Al}_{2} \mathrm{O}_{3}$. Catalyst Weight $=0.2 \mathrm{~g}$. Final temperature $=550^{\circ} \mathrm{C} \ldots \ldots \ldots \ldots 24$

4.2 Temperature-programmed reduction profile for $\mathrm{MoS}_{y} / \mathrm{Al}_{2} \mathrm{O}_{3}$. Catalyst Weight $=0.2 \mathrm{~g}$. Final temperature $=450^{\circ} \mathrm{C} \ldots \ldots \ldots \ldots 25$

4.3 Effect of thermal decomposition heating rate on HDS activity. Continuous method. Catalyst Weight $=0.2 \mathrm{~g}$. Catalyst prepared by flash and $10^{\circ} \mathrm{C} / \mathrm{min}$ thermal decomposition of ATTM in He followed by TPR . . . . . . . . . . 29

4.4 Effect of reduction temperature on HDS activity. Continuous method. Catalyst Weight $=0.2 \mathrm{~g}$. Catalyst prepared by $10^{\circ} \mathrm{C} / \mathrm{min}$ decomposition of ATTM followed by TPR to $420^{\circ} \mathrm{C}$ and $550^{\circ} \mathrm{C} \ldots \ldots \ldots \ldots$

4.5 Effect of catalyst preparation on HDS activity. Continuous method. Catalyst Weight $=0.2$ g. Catalyst prepared by $\mathrm{H}_{2}$ reduction of ATTM, and reductive sulfiding of $\mathrm{MoO}_{3}$ and Harshaw $0402 \mathrm{~T}$ followed by TPR. . . . . 34

4.6 Effect of catalyst preparation on HDS activity. Continuous method. Catalyst Weight $=0.2 \mathrm{~g}$. Catalysts prepared by $\mathrm{H}_{2}$ reduction of ATTM and Harshow 0402T. ......................... 35

4.7 Effect of thermal decomposition heating rate on HDS activity. Pulse method. Catalyst Weight $=0.2 \mathrm{~g}$. Catalyst prepared by flash and $10^{\circ} \mathrm{C} / \mathrm{min}$ thermal decomposition of ATTM in He followed by TPR ........... 38

ix 
4.8 Effect of reduction temperature on HDS activity. Pulse method. Catalyst Weight $=0.2 \mathrm{~g}$. Catalyst prepared by $10^{\circ} \mathrm{C} / \mathrm{min}$ decomposition of ATTM followed by TPR to $420^{\circ} \mathrm{C}$ and $550^{\circ} \mathrm{C} \ldots \ldots \ldots \ldots \ldots$

4.9 Effect of catalyst preparation on HDS activity. Pulse method. Catalyst Weight $=0.2 \mathrm{~g}$. Catalyst prepared by $\mathrm{H}_{2}$ reduction of ATTM, and reductive sulfiding of $\mathrm{MoO}_{3}$ and Harshaw 0402T followed by TPR. . . . . . . . . . 40

4.10 Effect of catalyst preparation on HDS activity. Pulse method. Catalyst Weight $=0.2 \mathrm{~g}$. Catalysts prepared by $\mathrm{H}_{2}$ reduction of ATTM and Harshow 0402 T. . . . . . . . . . . . . . . . . .

4.11 Separation of reaction products during thiophene HDS reaction. Pulse method. Catalyst Weight $=0.2$ g. Catalyst prepared by $\mathrm{H}_{2}$ reduction of ATTM at $15^{\circ} \mathrm{C} / \mathrm{min}$ to $550^{\circ} \mathrm{C} . \ldots \ldots \ldots \ldots \ldots$

$4.12 \mathrm{H}_{2} \mathrm{~S}$ Concentration in thiophene HDS products. Catalyst Weight $=0.2 \mathrm{~g}$. Catalyst prepared by $\mathrm{H}_{2}$ reduction of ATTM . . . . . . . . . 45

4.13 The separation of reaction products for thiophene hydrogenolysis. Continuous method. Catalyst Weight $=0.2 \mathrm{~g}$. Catalyst prepared by $\mathrm{H}_{2}$ reduction of ATTM at $15^{\circ} \mathrm{C} / \mathrm{min}$ to $550^{\circ} \mathrm{C} \ldots \ldots \ldots \ldots \ldots \ldots$

4.14 Propylene HYD activity measured by a pulse method . . . . . . . . 49

4.15 Effect of reaction temperature on HYD activity. Catalyst Weight $=0.2 \mathrm{~g}$. $\mathrm{H}_{2}: \mathrm{C}_{3} \mathrm{H}_{6}=1.5: 1$. Catalysts prepared by the reduction of ATTM in $\mathrm{H}_{2}$. .

4.16 Effect of reaction temperature on HYD activity. Catalyst Weight $=0.05 \mathrm{~g}$. $\mathrm{H}_{2}: \mathrm{C}_{3} \mathrm{H}_{6}=5: 1$. Catalysts prepared by the reduction of ATTM in $\mathrm{H}_{2}$. .

4.17 Effect of thermal decomposition heating rate on HYD activity. Catalyst Weight $=0.2 \mathrm{~g} \cdot \mathrm{T}=50^{\circ} \mathrm{C} . \mathrm{H}_{2}: \mathrm{C}_{3} \mathrm{H}_{6}=1.5: 1$ Catalysts prepared by flash and $10^{\circ} \mathrm{C} / \mathrm{min}$ thermal decomposition of ATTM in He followed by TPR. . . . .

4.18 Effect of catalyst preparation on HYD activity. Catalyst Weight $=0.2 \mathrm{~g}$. $\mathrm{T}$ $=50^{\circ} \mathrm{C} . \mathrm{H}_{2}: \mathrm{C}_{33} \mathrm{H}_{6}=1.5: 1$. Catalysts prepared by $\mathrm{H}_{2}$ reduction of ATTM, and reductive sulfiding of $\mathrm{MoO}_{3}$ and Harshaw $0402 \mathrm{~T}$ followed by TPR. . . . 
4.19 Effect of sample size on HYD activity. $\mathrm{T}=50^{\circ} \mathrm{C} . \mathrm{H}_{2}: \mathrm{C}_{3} \mathrm{H}_{6}=1.5: 1$. Catalyst prepared by $10^{\circ} \mathrm{C} / \mathrm{min}$ thermal decomposition of ATTM in He followed by TPR

$4.20 \mathrm{C}_{3} \mathrm{H}_{6}$ effluent during temperature-programmed regeneration of catalyst . .

4.21 Effect of reactant concentration on HYD activity. Catalyst Weight $=0.2 \mathrm{~g}$. $\mathrm{T}=50^{\circ} \mathrm{C}$. Catalysts prepared by $10^{\circ} \mathrm{C} / \mathrm{min}$ thermal decomposition of ATTM in He followed by TPR. . . . . . . . . . . . . . .

4.22 Catalyst regeneration by heating in $\mathrm{H}_{2}$ at $15^{\circ} \mathrm{C} / \mathrm{min}$ to $550^{\circ} \mathrm{C}$. Catalyst Weight $=0.08 \mathrm{~g} . \mathrm{T}=50^{\circ} \mathrm{C} \cdot \mathrm{H}_{2}: \mathrm{C}_{3} \mathrm{H}_{6}=1.5: 1$. Catalysts prepared by $10^{\circ} \mathrm{C} / \mathrm{min}$ thermal decomposition of ATTM in He followed by TPR. . . . .

4.23 TPD profiles for $\mathrm{Mo} / \mathrm{Al}_{2} \mathrm{O}_{3}$ and $\mathrm{CoMo} / \mathrm{Al}_{2} \mathrm{O}_{3}$ catalysts (a) ATTM/ $/ \mathrm{Al}_{2} \mathrm{O}_{3}$ : $10^{\circ} \mathrm{C} / \mathrm{min}+\mathrm{TPR}$ to $550^{\circ} \mathrm{C}$ (b) $\mathrm{ATTM} / \mathrm{Al}_{2} \mathrm{O}_{3}: 10^{\circ} \mathrm{C} / \mathrm{min}+\mathrm{TPR}$ to $420^{\circ} \mathrm{C}$ (c) $\operatorname{ATTM} / \mathrm{Al}_{2} \mathrm{O}_{3}:$ Flash $+\mathrm{TPR}$ to $550^{\circ} \mathrm{C}$ (d) $\mathrm{ATTM} / \mathrm{Al}_{2} \mathrm{O}_{3}: \mathrm{H}_{2}$ reduction (e) ATTM $/ \mathrm{Al}_{2} \mathrm{O}_{3}: 10^{\circ} \mathrm{C} / \mathrm{min}+$ Reductive sulfiding +TPR (f) Harshaw: Reductive sulfiding + TPR (g) Harshaw: $\mathrm{H}_{2}$ Reduction (h) $\mathrm{MoO}_{3} / \mathrm{Al}_{2} \mathrm{O}_{3}$ :

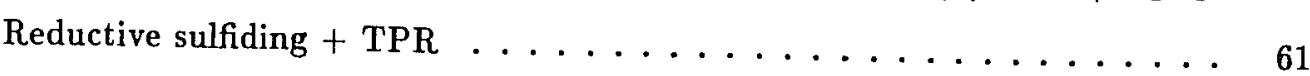

4.24 Effect of reduction temperature on TPD profiles. Catalyst Weight $=0.2 \mathrm{~g}$. Catalyst prepared by thermal decomposition of ATTM at $10^{\circ} \mathrm{C} / \mathrm{min}$ in He followed by TPR to $(\mathrm{a}) 420^{\circ} \mathrm{C}$ (b) $550^{\circ} \mathrm{C} \ldots \ldots \ldots \ldots$

4.25 Effect of thermal decomposition heating rate on TPD profiles. Catalyst Weight $=0.2 \mathrm{~g}$. Catalyst prepared by (a) flash decomposition at $450^{\circ} \mathrm{C}$ (b) $10^{\circ} \mathrm{C} / \mathrm{min}$ decomposition to $450^{\circ} \mathrm{C}$, followed by $\mathrm{TPR} \ldots \ldots \ldots 64$

4.26 Effect of preparation technique on TPD profile. Catalyst Weight $=0.2 \mathrm{~g}$. (a) Harshaw 0402T: Reductive sulfiding + TPR. (b) $\mathrm{MoO}_{3} / \mathrm{Al}_{2} \mathrm{O}_{3}$ : Reductive sulfiding + TPR. (c)ATTM $/ \mathrm{Al}_{2} \mathrm{O}_{3}: \mathrm{H}_{2}$ reduction $\ldots \ldots \ldots 66$

4.27 TPD profiles for unsupported ATTM (a) flash decomposition (b) $10^{\circ} \mathrm{C} / \mathrm{min}$ decomposition, in He followed by TPR [Kalthod, 1985] . . . . . . 67

$x i$ 
4.28 TPR profiles for Co-promoted and unpromoted molybdenum sulfide catalysts (a) $\mathrm{CoMo} / \mathrm{Al}_{2} \mathrm{O}_{3}$ (b) $\mathrm{Mo} / \mathrm{Al}_{2} \mathrm{O}_{3} \ldots \ldots \ldots \ldots \ldots$

4.29 TPR profiles for unsupported (a) unpromoted ATTM (b) Co-promoted ATTM $[$ Kalthod, 1985] ....................... 71

4.30 Propylene HYD activity for Co-promoted and unpromoted catalysts. Catalyst Weight $=0.08$ g. $\mathrm{T}=50^{\circ} \mathrm{C} . \mathrm{H}_{2}: \mathrm{C}_{3} \mathrm{H}_{6}=1.5: 1$. Catalysts prepared by thermal decomposition of CTTM and ATTM in He at $10^{\circ} \mathrm{C} / \mathrm{min}$ followed by

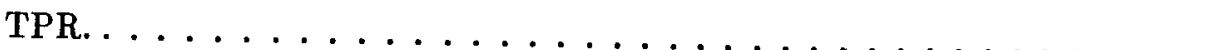

4.31 Thiophene HDS activity for Co-promoted and unpromoted catalysts. Catalyst Weight $=0.2 \mathrm{~g}$. Catalysts prepared by thermal decomposition of CTTM and ATTM in He at $10^{\circ} \mathrm{C} / \mathrm{min}$ followed by TPR. . . . . . . . . . . 74

4.32 TPD profiles for Co-promoted and unpromoted sulfide molybdenum catalyst. Catalyst Weight $=0.2$ g. (a) $\mathrm{Mo} / \mathrm{Al}_{2} \mathrm{O}_{3}$ (b) $\mathrm{CoMo} / \mathrm{Al}_{2} \mathrm{O}_{3} \ldots \ldots \ldots$.

4.33 Propylene HYD activity for Co-promoted ATTM $/ \mathrm{Al}_{2} \mathrm{O}_{3}$ and Co-promoted $\mathrm{MoO}_{3} / \mathrm{Al}_{2} \mathrm{O}_{3}$. Catalyst Weight $=0.08$ g. $\mathrm{T}=50^{\circ} \mathrm{C} . \mathrm{H}_{2}: \mathrm{C}_{3} \mathrm{H}_{6}=1.5: 1$. Catalysts prepared by (a) thermal decomposition of CTTM in $\mathrm{He}$ at $10^{\circ} \mathrm{C} / \mathrm{min}$ followed by TPR.(b) Co- $\mathrm{MoO}_{3} / \mathrm{Al}_{2} \mathrm{O}_{3}$ prepared by reductive sulfiding followed by TPR ............................. 77

4.34 IR spectrum of freshly prepared ATTMi $\ldots \ldots \ldots \ldots \ldots$

4.35 IR spectrum of ATTM exposed to air for 48 hours $\ldots \ldots \ldots \ldots$

B.1 BET plot for the catalyst prepared by $10^{\circ} \mathrm{C} / \mathrm{min}$ decomposition followed by TPR and TPD. BET area $=171.7\left(\mathrm{~m}^{2} / \mathrm{g}\right) \ldots \ldots \ldots . \ldots . \ldots$

C.1 Integration Constant for $\mathrm{H}_{2} \mathrm{~S}$ Evolution $\ldots \ldots \ldots \ldots \ldots$

D.1 Separation of reaction products by GC for thiophene HDS and propylene HYD (a) Thiophene HDS (b) Propylene HYD . . . . . . . . . . . . 101 


\section{ABSTRACT \\ CHARACTERIZATION OF SUPPORTED MOLYBDENUM SULFIDE CATALYST EX AMMONIUM TETRATHIOMOLYBDATE \\ by \\ Fan Zhang \\ University of New Hampshire, December, 1995}

Active sulfide catalysts are conventionally prepared by converting the respective oxides to sulfides. Reductive sulfiding of the oxides is usually difficult and does not proceed in a regular manner. In this dissertation, a supported molybdenum sulfide catalyst prepared by the decomposition of ammonium tetrathiomolybdate (ATTM) in hydrogen and helium was studied. The catalyst is unique in two respects, namely, the lower valence state of the supported molybdenum sulfide catalyst, and the presence of few oxygen atoms in the catalyst. The thiophene hydrodesulfurization (HDS) and propylene hydrogenation (HYD) activities of a catalyst prepared by this technique (and subjected to different pretreatments) are compared with the activities of both a conventional and a commercial catalyst. The pretreatments consisted of flash or temperature programmed decomposition of the supported ATTM in helium followed by removal of excess sulfur by temperature programmed reduction (TPR), or reduction in hydrogen. The results clearly indicate that the activity of the catalyst prepared by the decomposition of ATTM is much higher than the activities of both the conventionally prepared catalyst and the commercial catalyst, probably due to its lower valence state. In order to understand the nature of surface and catalytic sites, temperature programmed desorption (TPD) of hydrogen sulfide, low temperature oxygen chemisorption (LTOC), and BET area measurement have been conducted. Finally, the activity of a cobalt promoted molybdenum sulfide catalyst prepared by the decomposition of the thiosalt was investigated. For the same pretreatment, the Co-promoted catalyst has a higher HDS activity but a similar HYD activity compared to the unpromoted catalyst.

xiii 


\section{Chapter 1}

\section{INTRODUCTION}

Sulfide catalysts play a vital role in the petroleum and coal industries, especially in hydrogenolysis, hydrogenation and hydrocracking processes. The most widely used sulfide catalysts are sulfides of metals of Group VI (Mo, W) and Group VIII (Co, Ni) of the periodic table. Compared to other catalysts, sulfide catalysts have a special position due to their outstanding resistance to catalyst poisons and high adsorption capacity of hydrogen and unsaturated hydrocarbons. In industrial applications, sulfide catalysts are usually exposed to rather extreme conditions, necessitating a high mechanical strength. The carrier most often used is alumina, which is a part of the cobalt-molybdena desulfurizing catalyst. The active gamma modification of alumina is suitable for catalytical purposes.

Natural sulfide minerals are frequently inefficient as catalysts since their activity may be very low. Therefore, catalytically active sulfides are conventionally prepared by means of special procedures. The starting substances are converted to oxides by means of calcination or oxidation. Active sulfide catalysts are usually prepared by further converting the respective oxides to sulfides. For example, in reductive sulfiding, a $\mathrm{H}_{2} \mathrm{~S} / \mathrm{H}_{2}$ mixture reacts with $\mathrm{MoO}_{3}$ at 400 to $500^{\circ} \mathrm{C}$, resulting in reduction to $\mathrm{MoO}_{2}$ and partial conversion to sulfide, so that the final product is a mixture of $\mathrm{MoS}_{2}$ and $\mathrm{MoO}_{2}$ [26]. But reductive sulfiding of molybdenum oxides is difficult and does not proceed in a regular manner[57].

Another method of preparing active unsupported molybdenum sulfide catalysts is to decompose the thiosalt in an inert atmosphere [32]. Extensive research work has been done on unsupported molybdenum sulfide catalyst prepared by the decomposition of ammonium tetrathiomolybdate (ATTM) in helium $[17,18]$. This technique was first applied to 
supported sulfide catalysts by Vasudevan et al. [54]. In their research, alumina was impregnated with aqueous ammonium tetrathiomolybdate, not the heptamolybdate salt, followed by decomposition in hydrogen [54]. By studying the hydrogen uptake in reduction process, Vasudevan and Weller found a significant difference in the Mo valence state between the unsupported and alumina-supported sulfide. The average valence state of Mo for the reduced supported sulfide was much less than 4 , whereas for the unsupported sulfide and supported conventional oxide catalysts, the valence state were equal to 4 , which is indeed remarkable. In the case of supported molybdenum sulfide, the lower valence state probably results in a higher concentration of anion vacancies. It is believed that supported catalysts prepared by the decomposition of the respective thiosalt in hydrogen will therefore have higher activities compared to catalysts prepared by reductive sulfiding of the oxide, in which molybdenum is presented as Mo(IV). However, the activity of the supported catalyst for different reactions, such as in hydrogenation or hydrogenolysis had not been investigated prior to this work.

Supported sulfide catalysts are surface structure sensitive catalysts. In other words, different reactions will happen on functionally different sites which are affected by surface structures. Thermal decomposition of ATTM in helium instead of hydrogen produces molybdenum sulfide containing excess (non-stoichiometric) sulfur. The heating rate during thermal decomposition affects product morphology. The effect of various pretreatments such as temperature-programmed reduction in hydrogen or reductive sulfiding in a hydrogen sulfide/hydrogen mixture, whereby the excess sulfur is removed, also greatly influences the catalyst morphology and is definitely worth examining.

Low temperature oxygen chemisorption (LTOC) has been widely used to characterize Mo catalysts in the sulfide and oxide states $[14,34,52]$. The strong chemisorption of oxygen or NO indicates the presence of uncoordinated centers in sulfided catalysts, which are generally assumed to be the active sites for hydrogenation and hydrogenolysis reactions $[6,9,39,41,49]$. These centers are also referred to as anion vacancies located at the edges of the $\mathrm{MoS}_{2}$-like slabs, where Mo atoms are incompletely coordinated with $\mathrm{S}^{2-}$ ions [41]. An approach to study the anion vacancies is to measure $\mathrm{H}_{2} \mathrm{~S}$ evolution from the 
surface during temperature-programmed desorption (TPD) of hydrogen sulfide. A detailed investigation of LTOC and TPD for supported catalysts prepared by decomposition of ATTM will significantly add to the understanding of the nature of the surface and provide important information regarding the correlation between catalyst acíivity and active sites.

Extensive research has been done on unsupported molybdenum catalysts $[16,17,18]$. Compared to supported catalysts which are affected by interaction between catalyst and support, unsupported molybdenum catalyst has the advantage of easier measurement of crystal structure, stoichiometric state and surface. In this research, results from the characterization of supported and unsupported molybdenum catalysts prepared by the same procedure are carefully compared. The observations will provide information regarding morphology and active sites of supported catalysts.

In the petrochemical industry or in coal liquefaction, molybdenum catalysts promoted with cobalt were found to be effective in a number of reactions such as hydrodesulfurization or the gas shift reaction. It will be very useful and interesting to characterize the activity of a supported Co-promoted molybdenum sulfide catalyst prepared by the decomposition of ATTM and cobalt nitrate, in "test" reactions such as thiophene hydrodesulfurization (HDS) or propylene hydrogenation (HYD). Judging by previous analysis for supported molybdenum sulfide catalysts prepared by the decomposition of the ATTM in hydrogen, one can surmise that the valence state of the supported Co-promoted catalyst would probably be lower than the valence state of a Co-promoted catalyst prepared by a conventional method. The importance of comparing the activities of the two catalysts prepared by the two different techniques cannot be emphasized enough.

The broad objectives of this dissertation are therefore as follows:

1. To prepare supported molybdenum sulfide, and Co-promoted molybdenum sulfide catalysts by the decomposition of the thiosalt in hydrogen and/or helium.

2. To study the effect of various pretreatments of the catalysts decomposed in helium on oxygen chemisorption, temperature-programmed desorption, catalyst activity, and the correlation between them. 
3. To compare the hydrogenolysis and hydrogenation activities of the novel catalyst with the activities of conventional catalysts.

4. To compare activities measured by a pulse technique and a continuous technique in thiophene HDS reaction.

5. To determine the activity of a supported Co-promoted molybdenum sulfide catalyst and compare the results with the activity of an unpromoted catalyst and a conventional promoted oxide catalyst.

6. To improve the storage stability of the supported sulfide catalyst prepared by this technique.

This dissertation is divided into five chapters. Chapter 2 gives a literature review on the general properties of sulfide catalysts and on other topics that are most relevant to this dissertation. Chapter 3 describes the experimental setup, materials, and procedures used in this dissertation. Chapter 4 presents the results from activity measurement of the catalyst, then discusses the catalytic active sites of the catalyst with the help of TPD, LTOC and BET measurements. Finally, the conclusions and recommendations for further research are presented in Chapter 5. 


\section{Chapter 2}

\section{LITERATURE REVIEW}

\subsection{General Properties of Sulfide Catalysts}

In a number of ways, sulfide catalysts differ from the classical catalysts, mainly metallic catalysts, and make it the most significant catalyst for hydroprocessing reactions[57].

Compared to other types, sulfide catalysts have a special position due to their outstanding resistance to catalyst poisons. In most cases, even in the presence of sulfide compounds, sulfide catalysts can maintain a high activity and a long lifetime. Metallic and other types of catalysts can easily be poisoned, especially by sulfide compounds, which will completely eliminate their catalytic function. Sulfide catalysts are also very resistant to carbonaceous deposits on the catalyst surface, thus they can be used in hydrocracking and in hydrotreating processes in which coke is easily deposited on other catalysts, deactivating them totally.

Metal sulfides, such as the sulfides of metals of Group VI of the periodic table (Mo and $W$ ), are typical high temperature catalysts. Differing from metallic catalysts, a number of which are active in hydrogenation at room temperature only, sulfide catalysts mostly become active at the high temperature at which hydroprocessing happens.

A high adsorption capacity for hydrogen and unsaturated hydrocarbons is a significant property of the most important sulfide catalysts. The variation of the hydrogen surface concentration with temperature is considerably less on sulfide catalysts compared with metallic ones, so that a sufficient hydrogen concentration is maintained on the catalyst surface in hydrogenation reactions even at the high reaction temperatures. 
The catalytic activity of metal sulfides is related to the defects in their crystal lattice. Electron microscopy studies of unsupported molybdenum sulfide have shown that it exhibits hexagonal morphology [41]. The two most important sulfides, $\mathrm{MoS}_{2}$ and $\mathrm{WS}_{2}$, have a similar crystal structure as shown in Figure 2.1. For molybdenite, $\mathrm{MoS}_{2}, \mathrm{Mo}$ and $\mathrm{S}$ are shown by solid and open circles, respectively. The metal layers are separated by two layers of sulfur atoms. The basal plane, which is the horizontal plane in this figure, consists of $\mathrm{S}$ atoms; and the edge planes, which are the vertical planes, contain $S$ atoms and coordinatively unsaturated Mo sites.

A similar morphology is presumed to be present in supported molybdenum sulfide catalysts. The molybdenum sulfide hexagons exist as two-dimensional slabs about a layer thick and this is attributed to a strong interaction of the molybdenum oxide with the alumina support. It is presumed that during subsequent sulfiding, a high dispersion of molybdenum that originally existed during preparation and calcination is still maintained. The active sites of molybdenum sulfide catalysts, which have been studied extensively by researchers $[15,27,39,55]$, are believed to consist of coordinatively unsaturated Mo sites (CUS) and the associated anion vacancies.

\subsection{Unsupported Molybdenum Catalyst from ATTM}

Extensive research work has been done on the unsupported molybdenum sulfide catalyst by Kalthod and Weller $[16,17,18]$. The catalyst was prepared $i n$-situ, by the thermal decomposition of ATTM in helium. They found that the initial catalyst contained excess sulfur $(S / M o=2.3-2.4)$, had a high surface area and showed little oxygen chemisorption. Temperature programmed reduction (TPR) in hydrogen showed the appearance of two peaks of hydrogen sulfide, centered at about $180^{\circ} \mathrm{C}$ and $380^{\circ} \mathrm{C}$. The specific oxygen chemisorption increased with increasing reduction temperatures. They also found that negligible sintering occurred during removal of sulfur corresponding to the first TPR peak; however, sintering occurred during the second TPR peak and increased when the sample was maintained in hydrogen at $450^{\circ} \mathrm{C}$. 


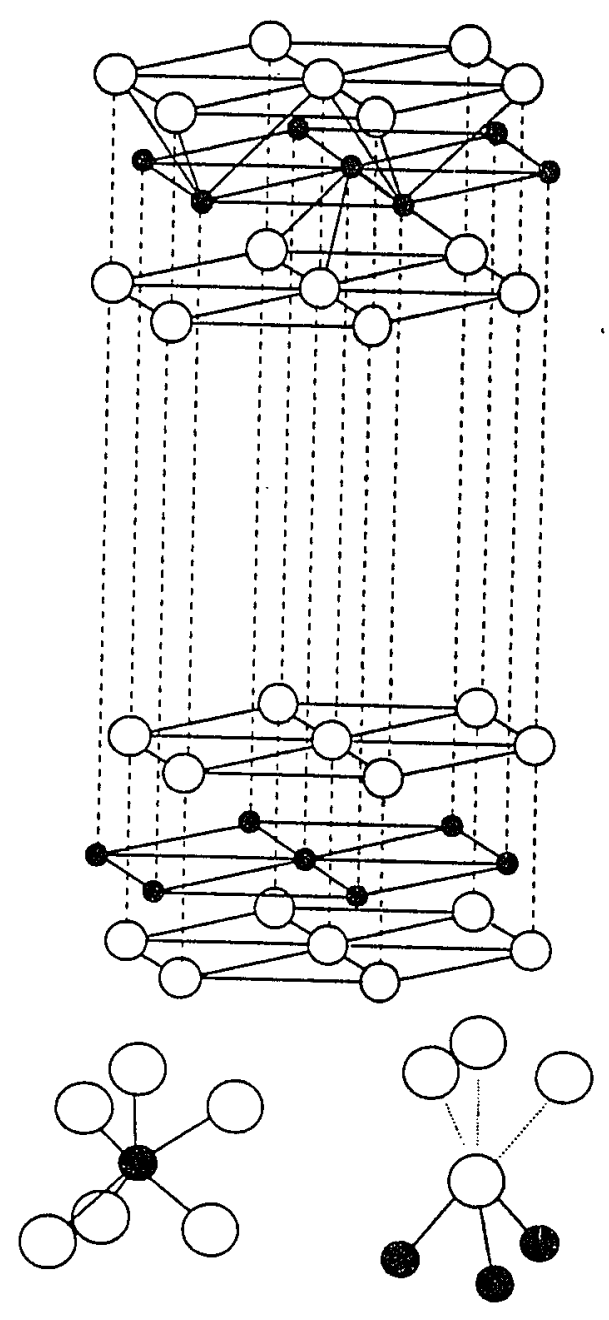

Figure 2.1: Crystal structure of hexagonal $\mathrm{MoS}_{2}$, - - Mo atom, o- S atom [Vukasovich, 1978] 
The catalyst activity was tested by propylene hydrogenation after various pretreatments [18]. It was found that the specific activity increased with removal of non-stoichiometric sulfur and the apparent activation energy decreased at the same time.

\subsection{Valence States}

Valyon and Hall published a method of assaying reductively sulfided molybdenaalumina catalysts [53], with a view to establishing whether valence states lower than Mo(IV) exist in such preparations. Valyon and Hall started with a molybdenum oxide-alumina catalyst, prepared by impregnation of alumina with aqueous ammonium heptamolybdate, followed by drying and precalcination. Treatment with a $\mathrm{H}_{2} \mathrm{~S} / \mathrm{H}_{2}$ mixture resulted in reduction and replacement of $\mathrm{O}$ by $\mathrm{S}$, the extent of both depended on reaction conditions. The salient finding was that valence states lower than Mo(IV) were indeed present (though not much lower) in these reductively sulfided catalysts. Valyon and Hall also speculated that the catalytic properties of such a reductively sulfided catalyst supported on alumina may not differ much from that of $\mathrm{MoS}_{2}$.

A technique for preparing supported molybdenum sulfide catalysts was developed by Vasudevan and Weller, in which alumina was impregnated with aqueous ammonium tetrathiomolybdate (ATTM) followed by decomposition in hydrogen [54]. The hydrogen consumption for reduction of ATTM, and oxygen consumption for reoxidation of the reduced catalyst were rationalized on the basis of a postulated model in which the Mo valence state can be calculated. Compared to the technique of Valyon and Hall, this technique has the advantage that there is no need to replace lattice $O$ by $S$ on sulfidation [53]. Vasudevan and Weller found a significant difference in the average valence state of Mo between the unsupported and alumina-supported sulfide; i.e., the average valence state for the reduced supported sulfide was considerably less than 4 , whereas for the unsupported sulfide, the stoichiometry appeared to be $S / M O=2$ after $\mathrm{H}_{2}$ reduction.

Recent work in the literature regarding the valence state of reduced molybdenum have corroborated the observations of Vasudevan and Weller. For instance, Goldwasser et al. [12] 
prepared a molybdenum catalyst by subliming $\mathrm{Mo}(\mathrm{Co})_{6}$ onto dehydroxylated and partially dehydroxylated alumina. The chemisorption of $\mathrm{NO}$ and $\mathrm{CO}$ on these materials was studied using volumetric, chromatographic, and spectroscopic techniques. ESCA data indicated that on partially dehydroxylated.alumina, both $\mathrm{Mo}(\mathrm{IV})$ and $\mathrm{Mo}(\mathrm{II})$ or $\mathrm{Mo}(0)$ were present.

Schrader et al. [8] have examined the effect of the oxidation state of molybdenum on the catalytic hydrodesulfurization (HDS) of thiophene using a series of lead-lutetium Chevrel phases. They found that both bulk structures and molybdenum oxidation states were stable. They were able to relate catalyst activity to the formal oxidation state of molybdenum for these compounds, and showed that thiophene HDS activity was associated with reduced molybdenum oxidation states, apparently reaching a maximum between $\mathrm{Mo}$ (II) and $\mathrm{Mo}(\mathrm{IV})$.

It has been suggested by Anderson et al. [1] that in view of the high hydrogen capacity of $\mathrm{MoS}_{2}$, it is appealing to consider $\mathrm{H}_{x} \mathrm{MoS}_{2}$ as the true catalytically active component for reactions involving dihydrogen. For unsupported $\mathrm{MoS}_{2}$ prepared by the decomposition of ATTM in the temperature range $150-300^{\circ} \mathrm{C}$. Knozinger et al. [20,35] have proposed a stoichiometry of $\mathrm{H}_{0.035} \mathrm{MoS}_{2}$ at $500 \mathrm{mbar}$ and $300^{\circ} \mathrm{C}$. In comparison, for supported molybdenum sulfide catalyst prepared by the decomposition of ATTM in $\mathrm{H}_{2}$, Vasudevan and Weller obtained a H/Mo ratio of 0.011 . The elementary steps leading to dihydrogen dissociation are not understood yet.

Chianelli and coworkers [42] have looked at edge surfaces in lithographically textured molybdenum disulfide. They found that the optical absorption that was measured increased by two orders of magnitude after texturing. This increase was attributed to surface defects that are located on edge planes. The presence of $\mathrm{Mo}(\mathrm{III})$ at the surface was hypothesized to be consistent with the sulfur vacancies or catalytically active sites.

There seems to be clear evidence that the average valence state for the reduced supported molybdenum sulfide is much less than 4 . The results obtained by these researchers strongly supports the objectives of this dissertation. 


\subsection{Active Sites and LTOC}

At the outset, it should be emphasized that despite extensive research in this area, considerable uncertainty regarding the nature of active sites, particularly in regard to the differentiation of functionally different sites for different reactions, still exists. The catalytic sites in the sulfide form of $\mathrm{Mo} / \mathrm{Al}_{2} \mathrm{O}_{3}$ catalysts are believed to consist of coordinately unsaturated Mo sites (CUS) and the associated anion vacancies $[15,27,39,55]$.

Various models have been proposed for the active sites in hydrogenation and hydrogenolysis reactions on promoted and unpromoted molybdenum sulfide catalysts. It is now generally assumed that the active sites are associated with the edge plane on $\mathrm{MoS}_{2}$ $[6,41,49]$ and that the basal plane is not reactive [9].

Tanaka et al [46] showed the importance of coordinate unsaturation of Mo atoms by studying $\mathrm{C}_{4} \mathrm{H}_{8}$ hydrogenation and isomerization on a single $\mathrm{MoS}_{2}$ crystal. They characterized the coordinate unsaturation sites and found that hydrogenation of olefins occurred on edge/corner Mo atoms with 3 CUS sites, and isomerization on edge Mo atoms with 2 CUS sites.

Kasztelan et al. [19] proposed that a modeled $\mathrm{MoS}_{2}$ slab exhibits two different edge planes. Different degrees of unsaturation can be obtained depending on which edge plane is considered. Only the (1010) edge plane can present more than 2 coordinated unsaturations, from 1 up to 4.

Reddy and co-worker [40] characterized a series of sulfided Co- $\mathrm{Mo} / \mathrm{Al}_{2} \mathrm{O}_{3}$ hydroprocessing catalysts by oxygen and hydrogen chemisorption. They suggested that hydrogenolysis and hydrogenation sites are structured differently. The oxygen chemisorption at $-78^{\circ} \mathrm{C}$ can titrate the number of coordinately unsaturated sites, but it can not distinguish between two CUS with different intrinsic activity or between a hydrogenolysis and a hydrogenation site.

Chemisorption of oxygen is widely used to characterize Mo catalysts in the sulfide and oxide states $[14,34,52]$. The strong chemisorption of oxygen or NO indicates the presence of uncoordinated centers in sulfided catalysts. The amount of oxygen or NO chemisorption has been found to correlate with the catalytic activity for hydrogenation 
(HYD) [2, 24], and hydrodesulfurization (HDS) [28, 30, 47, 51, 58]. The amount of oxygen chemisorption per unit area of the catalyst depends on the temperature, the method of preparation/pretreatment, and the method of measurement. The effect, if any, of the edge and basal sites of the sulfide in oxygen chemisorption is still not clear, even though this has been investigated rather extensively $[43,47]$.

Two-isotherm methods are standard methods for the measurement of chemisorption [16]. The first isotherm measures physical adsorption and chemisorption. The second isotherm, which is developed after purging the sample to remove physically adsorbed gas, measures physical adsorption only. The difference between the two isotherms indicates the amount of chemisorption. If the chemisorption is small, the dead volume of the system and physical adsorption correction may introduce large errors in the calculated chemisorption.

The pulse method for chemisorption involves injecting known volume oxygen pulse into a carrier gas flowing over the catalyst and detecting the un-adsorbed amount of oxygen. By this method, even low values of chemisorption can be measured by injecting small pulses. Freel [11] used the pulse method to measure hydrogen chemisorption on metals and found the results to be in good agreements with those from conventional methods. Kalthod [16] employed the pulse method for oxygen chemisorption on a commercial catalyst, Amocat 1-B. The results compared well with those results measured by conventional methods.

The effect of temperature on oxygen chemisorption was studied by Parekh and Weller [33] on reduced, supported $\mathrm{CoMo} / \mathrm{Al}_{2} \mathrm{O}_{3}, \mathrm{Mo} / \mathrm{Al}_{2} \mathrm{O}_{3}$ catalysts. It was suggested that for the temperatures higher than $0^{\circ} \mathrm{C}$, the possible reaction of reduced Mo with $\mathrm{O}_{2}$ might result in an indeterminate amount of bulk-phase oxidate. From their studies at temperatures ranging from $-195^{\circ} \mathrm{C}$ to $0^{\circ} \mathrm{C}$, they suggested that either $-195^{\circ} \mathrm{C}$ or $-78^{\circ} \mathrm{C}$ could be chosen as a standard temperature for oxygen chemisorption measurements. Compared to $-195^{\circ} \mathrm{C}$, $-78^{\circ} \mathrm{C}$ has the advantage of a negligible correction for physical adsorption. 


\subsection{Co-Mo Catalysts}

Molybdenum based catalysts are usually promoted with cobalt or nickel. The hydrogenation and hydrogenolysis activity of these catalysts usually reaches a maximum at an atomic ratio of the promoter in the range, 0.15-0.5. The origin of the catalytic synergy is still an unresolved problem. A vast amount of literature exists on interactions between $\mathrm{MoS}_{2}$ and promoter. It is important to point out that there does not appear to be any study on catalyst activity of Co-promoted molybdenum catalysts, prepared by the decomposition of the corresponding thiosalt.

Several models have been proposed for the surface structure of cobalt promoted molybdenum catalysts. The widely referred models are: the monolayer model, the intercalation model, the synergetic model [36], and a recently proposed model which assumes the presence of the Co-Mo-S phase $[48,49]$. The Co-Mo-S phase model was proposed by Topsoe and co-workers based on MES, EXAFS and other studies. It is suggested that the promoter, Co or $\mathrm{Ni}$, does not alter the basic two dimensional $\mathrm{MoS}_{2}$-like structure of the Mo catalyst, but substitutes for Mo and/or occupies a neighboring interstitial position in the edge plane. The combination has been identified as a separate phase (the Co-Mo-S phase) by MES and is claimed to be responsible for the HDS-associated reactions. It is observed that for a sulfided Co- $\mathrm{Mo} / \mathrm{Al}_{2} \mathrm{O}_{3}$ catalyst with a typical composition used in industry, part of the cobalt is located in the alumina [50].

Voorhoeve and Stuiver [55] pointed out that divalent ions such as $\mathrm{Co}$ and $\mathrm{Ni}$ can intercalate between the $\mathrm{MoS}_{2}$ layers inducing a surface reconstruction of the edge planes of the crystallites. Under the influence of promoter ions which fit best into the octahedral holes between the $\mathrm{MoS}_{2}$ layers, the Mo ions are displaced from their interstitial positions and thus exposed to the surface.

Reddy [39] and co-workers proposed that Co as a promoter changes the intrinsic activity of the HDS sites by altering the electron density around Mo. Therefore, the promoted catalysts have a higher HDS activity per site (CUS) than the unpromoted catalysts. But, unlike the HDS sites, the promoter does not alter the intrinsic activity of the HYD sites. 
Therefore, the HYD reaction appears to be a function of the number of active sites only. Even though correlation of oxygen chemisorption of sulfided unsupported/supported molybdenum sulfide catalysts with thiophene hydrogenolysis activity has been successful, similar attempts with Co-promoted catalysts have been unsuccessful [28]. Oxygen chemisorption may be suitable to characterize Mo catalysts, but has been shown not to correlate with HDS activity for CoMo catalysts [3, 59]. For supported CoMo or NiMo catalysts, the Co (Ni) phase, not the Mo phase, is the predominant one for HDS activity [49]. 


\section{Chapter 3}

\section{EXPERIMENTAL}

\subsection{Catalyst}

Ammonium tetrathiomolybdate (ATTM, $\left.\left(\mathrm{NH}_{4}\right)_{2} \mathrm{MoS}_{4}\right)$ was prepared by bubbling hydrogen sulfide through a solution of ammonium paramolybdate and ammonium hydroxide in water. Dark crimson ammonium tetrathiomolybdate crystals were formed and separated by filtration, and then dried and stored in a desiccator under vacuum. In order to prevent the catalyst from being oxidized, the impregnation was carried out at room temperature by introducing $\gamma$-alumina in a saturated solution of ATTM under a nitrogen "blanket" for 24 hours. The ATTM $/ \mathrm{Al}_{2} \mathrm{O}_{3}$ was dried under vacuum at room temperature and stored in a desiccator until used in an experiment.

The metal content in the supported catalyst was determined by a standard ASTM method using a Jones reductor column (Method D-3943). In order to use this method, the catalyst was first oxidized by air calcination at $500^{\circ} \mathrm{C}$ for 3 hours.

Thermal decomposition of ATTM in helium produces molybdenum sulfide containing excess (non-stoichiometric) sulfur according to the reaction

$$
\left(\mathrm{NH}_{4}\right)_{2} \mathrm{MoS}_{4} \longrightarrow 2 \mathrm{NH}_{3}+\mathrm{H}_{2} \mathrm{~S}+(3-y) \mathrm{S}+\mathrm{MoS}_{y}
$$

The supported ATTM was decomposed in-situ and there was no exposure of the resulting sulfide to air in any of the subsequent procedures to prevent the catalyst from being oxidized. 
Two heating schedules for thermal decomposition were used: flash heating (done by lowering the reactor into a preheated oven) or temperature-programmed heating. In flash heating, the final temperature of $450^{\circ} \mathrm{C}$ was maintained for 1 hour. In the case of temperature-programmed heating, the catalyst was heated at a rate of $10^{\circ} \mathrm{C} / \mathrm{min}$ up to $450^{\circ} \mathrm{C}$ and held at that temperature for 15 minutes.

In some experiments, thermal decomposition of supported ATTM was carried out in a stream of $\mathrm{H}_{2}$ instead of $\mathrm{He}$. The heating rate was $15^{\circ} \mathrm{C} / \mathrm{min}$ until the sample reached $550^{\circ} \mathrm{C}$, and the sample was thereafter held at that temperature for 1 hour. Thermal decomposition of supported ATTM in hydrogen produces molybdenum sulfide having a valence state lower than $4[54]$ according to the reaction

$$
\left(\mathrm{NH}_{4}\right)_{2} \mathrm{MoS}_{4}+y \mathrm{H}_{2} \longrightarrow\left(\mathrm{NH}_{4}\right)_{2} \mathrm{~S}+y \mathrm{H}_{2} \mathrm{~S}+\mathrm{MoS}_{3-y}
$$

The Co-promoted catalyst was prepared by impregnating vacuum dried ATTM $/ \mathrm{Al}_{2} \mathrm{O}_{3}$ with cobalt nitrate solution of appropriate concentration under a nitrogen blanket. The black cobalt tetrathiomolybdate (CTTM, $\left.\mathrm{CoMoS}_{4}\right)$ formed was washed, dried and stored in a vacuum desiccator at room temperature. The final catalyst had a dull grey color with a metal content equivalent to $1.5 \% \mathrm{CoO}$ and $11.0 \% \mathrm{MoO}_{3}$. The method may be termed as "ionic precipitation" and the ionic reaction is:

$$
\mathrm{MoS}_{4}^{-2}+\mathrm{Co}^{+2} \longrightarrow \mathrm{CoMoS}_{4}
$$

Thermal decomposition of Co-promoted catalyst in helium and hydrogen was conducted in a manner similar to ATTM catalyst. For unsupported CTTM, the S/Mo ratio of the catalyst after thermal decomposition in He is 3.9 [16]. This indicates a negligible sulfur

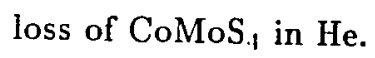

A commercial CoMo $/ \mathrm{Al}_{2} \mathrm{O}_{3}$ catalyst (Harshaw 0402T, $\mathrm{CoO} 3 \%, \mathrm{MoO}_{3} 15 \%$ ), and conventional oxide catalysts, $\mathrm{MoO}_{3} / \mathrm{Al}_{2} \mathrm{O}_{3}$ and $\mathrm{Co}-\mathrm{MoO}_{3} / \mathrm{Al}_{2} \mathrm{O}_{3}$, were used for comparison of catalyst activity. The conventional oxide catalysts were simply prepared by the calcination of $\mathrm{ATTM} / \mathrm{Al}_{2} \mathrm{O}_{3}$ or $\mathrm{CTTM} / \mathrm{Al}_{2} \mathrm{O}_{3}$ in a muffle furnace at $500^{\circ} \mathrm{C}$ for 12 hours, and they therefore have the same Mo loading as the $\mathrm{MoS}_{y}$ catalysts. 


\subsection{Equipment}

An integrated apparatus (shown in Figure 3.1) was used to measure the temperature programmed reduction profile, selective chemisorption, and activities. The system essentially consisted of a stainless-steel micro-reactor ( $\frac{1}{4}$ inch $\times 4 \frac{1}{4}$ inches) equipped with a preheating coil and an arrangement of valves and tubing that permitted in-situ preparation, pretreatment, pulsed chemisorption, and activity testing of catalysts. A gas chromatograph (Hewlett Packard 5890, Detector: TCD) was connected to the reactor through gas sampling valves and was used for pulsed chemisorption, reduction profile and activity measurements. All interconnecting tubings between the micro-reactor and the gas chromatograph were made of stainless-steel. The lines among the injection port, the microreactor and the line downstream of the reactor were wrapped with heating tape to prevent condensation of reactants. All the catalyst samples were prepared in-situ. In order to reduce transit time in the system, the intervening tubing was of narrow diameter at $\frac{1}{16}$ inch o.d.

\subsection{Experimental Procedure}

\subsubsection{Pretreatment}

Molybdenum sulfide catalyst prepared by the decomposition of ATTM or CTTM in helium was cooled to room temperature and subjected to one of the following pretreatments.

- Temperature-programmed reduction(TPR): The sample was heated at a heating rate of $15^{\circ} \mathrm{C} / \mathrm{min}$ in hydrogen till it reached $550^{\circ} \mathrm{C}$, and then held at that temperature for 1 hour. $\mathrm{H}_{2} \mathrm{~S}$ evolution was monitored by gas chromatography using an empty Teflon column of small diameter ( $\frac{1}{4}$ inch o.d.). The catalyst after TPR is assumed to be $\mathrm{MoS}_{y} / \mathrm{Al}_{2} \mathrm{O}_{3}(\mathrm{y} \leq 2)$ for $\mathrm{ATTM} / \mathrm{Al}_{2} \mathrm{O}_{3}$, and $\mathrm{MoO}_{2} / \mathrm{Al}_{2} \mathrm{O}_{3}$ for $\mathrm{MoO}_{3} / \mathrm{Al}_{2} \mathrm{O}_{3}$ and Harshaw catalyst.

- Reductive-sulfiding: The catalyst was heated at $15^{\circ} \mathrm{C} / \mathrm{min}$ in a $15.3 \% \mathrm{H}_{2} \mathrm{~S} / \mathrm{H}_{2}$ mixture to $450^{\circ} \mathrm{C}$ and kept at that temperature for 1 hour. After the sample was purged with 


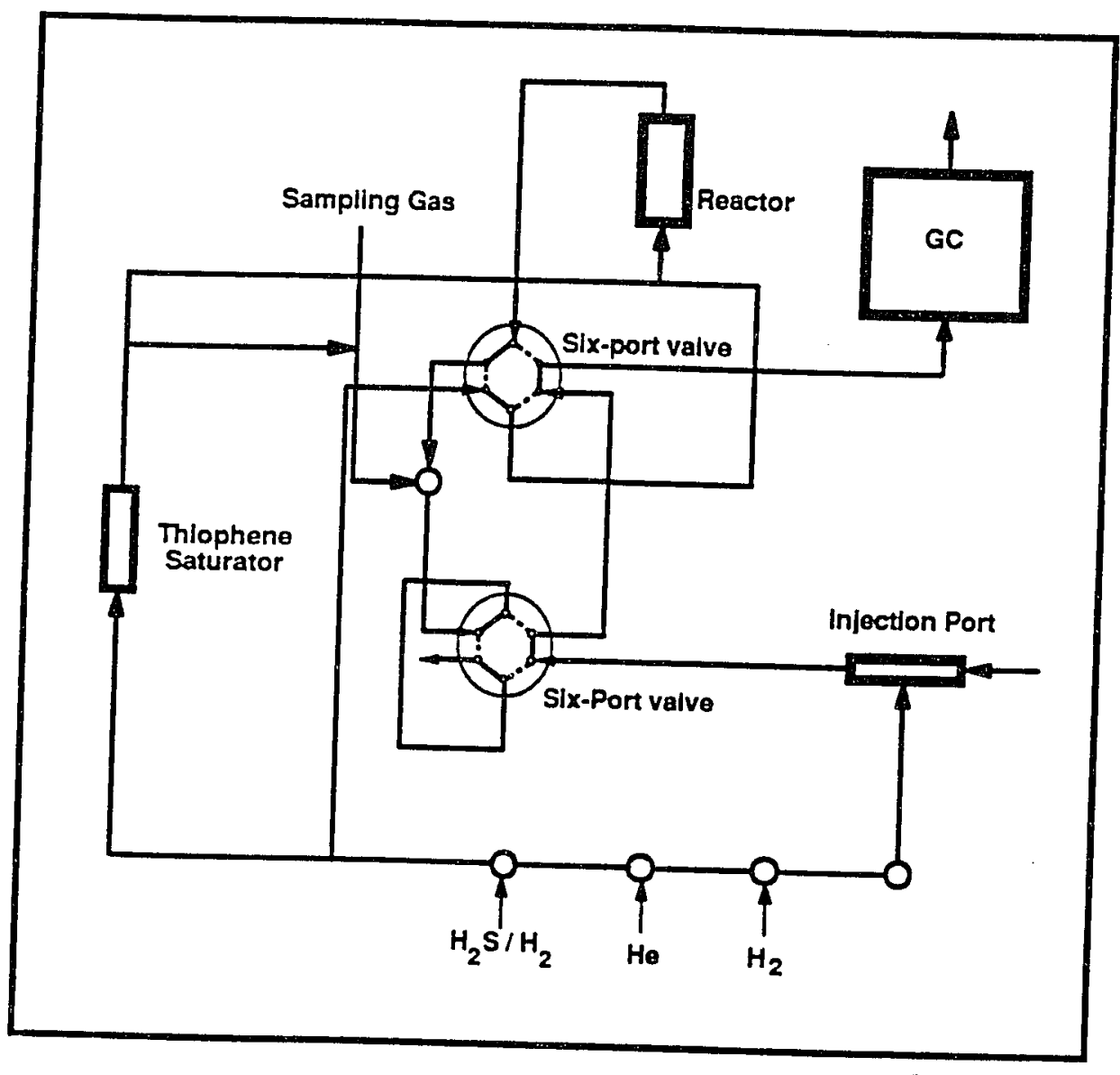

Figure 3.1: Schematic of Apparatus

17 
He at $450^{\circ} \mathrm{C}$ for 15 minutes, it was cooled to room temperature and then subjected to TPR. The catalysts after this pretreatment will be $\mathrm{MoS}_{y} / \mathrm{Al}_{2} \mathrm{O}_{3}$ for $\operatorname{ATTM} / \mathrm{Al}_{2} \mathrm{O}_{3}$, and $\mathrm{MoS}_{2}-\mathrm{MoO}_{2} / \mathrm{Al}_{2} \mathrm{O}_{3}$ for $\mathrm{MoO}_{3} / \mathrm{Al}_{2} \mathrm{O}_{3}$ and Harshaw catalyst.

\subsubsection{Pulse Adsorption Measurement}

Low temperature oxygen chemisorption (LTOC) at $-78^{\circ} \mathrm{C}$ was determined by a pulse method. Pulses of $1.51 \% \mathrm{O}_{2}$ in He were injected into a He carrier gas which passed through the catalyst bed (at $-78^{\circ} \mathrm{C}$ ) and then into the gas chromatograph for detection of unabsorbed $\mathrm{O}_{2}$. The catalyst was considered to be saturated when successive outlet pulses did not differ in composition by more than $1 \%$. The pulse volume was $1 \mathrm{~mL}$ or $5 \mathrm{~mL}$. The details of LTOC calculation are described in Appendix A.

\subsubsection{Temperature-Programmed Desorption (TPD)}

The catalyst after thermal decomposition in helium and TPR in hydrogen was cooled to room temperature and exposed to $15.3 \% \mathrm{H}_{2} \mathrm{~S} / \mathrm{H}_{2}(40 \mathrm{~mL} / \mathrm{min})$ for 20 minutes. Then the catalyst was purged with $\mathrm{He}$ for 30 minutes and heated in $\mathrm{H}_{2}$ at $15^{\circ} \mathrm{C} / \mathrm{min}$ to $420^{\circ} \mathrm{C}$ or $550^{\circ} \mathrm{C}$.

\subsubsection{BET Measurement}

A Quantasorb analyzer was used to determine the BET area by $\mathrm{N}_{2}$ adsorption at $195^{\circ} \mathrm{C}$. Nitrogen partial pressure was changed by regulating the flow rate of $\mathrm{N}_{2}$ in a $\mathrm{N}_{2} / \mathrm{He}$ mixture. An example of BET area measurement is presented in Appendix B.

\subsection{5 $\quad \underline{\mathrm{H}_{2} \mathrm{~S} \text { Evolution }}$}

$\mathrm{H}_{2} \mathrm{~S}$ evolution during TPR/TPD was determined from the total area under the TPR/TPD profile measured by gas chromatography and the $\mathrm{H}_{2} \mathrm{~S}$ calibration constant as described in Appendix C. 


\subsubsection{Measurement of Catalyst Activity}

Thiophene hydrodesulfurization (HDS) has been widely used as a model reaction for testing the hydrogenolysis activity of hydroprocessing catalysts. The catalyst activity can be measured by continuous and pulse methods, which provide steady state and initial activities of the catalyst, respectively.

In the continuous method, the catalyst was cooled to $400^{\circ} \mathrm{C}$ after pretreatment, and its activity was measured by flowing high purity hydrogen through a saturator containing thiophene maintained at a constant temperature. For each run, $0.2 \mathrm{~g}$ of catalyst was used, and the flow rate of hydrogen through the saturator was kept the same. The concentration of thiophene in the feed to the reactor as well as from the reactor outlet was monitored by a gas chromatograph. The HP5890 gas chromatograph was interfaced to a Zenith PC, and data-acquisition and analysis was performed by a software package, "Peak 96", supplied by Hewlett-Packard. The separation of thiophene, $\mathrm{H}_{2} \mathrm{~S}$, butane and butenes was achieved on a Durapak (n-octane/Porasil-C, $\frac{1}{8}$ inch $\times 24$ feet) column at $45^{\circ} \mathrm{C}$. Care was taken to ensure that no condensation of the thiophene occurred anywhere in the system by wrapping heating tape around the stainless-steel tubing.

In the pulse method, pulses of $2 \mu \mathrm{L}$ thiophene were injected into a hydrogen stream which carried the reactant through the catalyst bed into the gas chromatograph. For each run, $0.2 \mathrm{~g}$ of catalyst was used. Product detection was achieved on the same Durapak column used for the continuous system. A number of pulses were injected until the conversion remained fairly constant from pulse to pulse.

Catalyst HDS activity was expressed in terms of thiophene conversion as described in Appendix D. The activity of this catalyst was then compared to a commercial HDS catalyst (Harshaw CoMo 0402T, size 150 mesh), and a catalyst with the same molybdenum loading, but prepared by a conventional technique (reductive sulfiding of the oxide). In order to keep the molybdenum loading the same, the supported ATTM catalyst was simply oxidized at $500^{\prime \prime} \mathrm{C}$ for 12 hours, and then subjected to reductive sulfiding according to the procedure outlined earlier. After that, the sample was purged in He for 15 minutes, and subjected to 
temperature-programmed reduction.

Propylene hydrogenation (HYD) was selected to test the hydrogenation activity of the catalysts. In propylene hydrogenation, the catalyst was cooled to $50^{\circ} \mathrm{C}$ after various pretreatments and its activity was also determined by a continuous method. Propylene was mixed with $\mathrm{H}_{2}$ at various concentrations by adjusting the flow rate of each. The combined flow passed through the reactor at about $60 \mathrm{~mL} / \mathrm{min}$. Propylene and propane in the reaction product were analyzed by gas chromatography with a Durapak column at $30^{\circ} \mathrm{C}$. 


\section{Chapter 4}

\section{RESULTS AND DISCUSSION}

\subsection{Preparation of Catalyst}

Two sizes of alumina were tried as supports. Spherical pellets of $\gamma$-alumina from Davison having an average pore size of $125 \ddot{A}$, a diameter of $3.5 \mathrm{~mm}$, and a BET area of 176 $\mathrm{m}^{2} / \mathrm{g}$ were used. Powdered $\gamma$-alumina had an average diameter of $26 \mu \mathrm{m}$. The molybdenum contents are listed in Table 4.1.

It is clear from the table that alumina powder had a much higher molybdenum loading, probably due to the much smaller particle size, therefore resulting in a concomitant reduction in pore-diffusion. As a result, it was decided to conduct experiments with $\gamma$-alumina powder as support. Since a saturated solution of ATTM was used during impregnation, this was the highest loading that could be attained.

\subsection{Effect of Pretreatment on LTOC, BET Area and TPR}

Low temperature oxygen chemisorption (LTOC) has been applied to characterize sulfide hydroprocessing catalysts $[17,39,40,47]$. In these studies, advantage has been taken of the surface-specific adsorption behavior of oxygen on the edge planes of $\operatorname{MoS}_{2}$ crystallites to determine a correlation between the amount of oxygen chemisorption and the hydrogenolysis and hydrogenation activities of these catalysts. On unsupported $\mathrm{MoS}_{2}$, the amount of oxygen chemisorption has been found to be very sensitive to the type of the pretreatment [10]. But the effect of pretreatment on LTOC $\left(-78^{\circ} \mathrm{C}\right)$ for supported molybdenum sulfide catalyst made by thermal decomposition of the thiosalt has not been reported. 


\begin{tabular}{||l|c|c||}
\hline Catalyst & $\mathrm{BET}$ area $\left(\mathrm{m}^{2} / \mathrm{g}\right)$ & $\mathrm{MoO}_{3}(\mathrm{wt} \%)$ \\
\hline$\gamma-\mathrm{Al}_{2} \mathrm{O}_{3}$ pellet & 172.9 & 0.0 \\
$\mathrm{ATTM} / \gamma-\mathrm{Al}_{2} \mathrm{O}_{3}$ pellet & 176.0 & 3.72 \\
$\gamma-\mathrm{Al}_{2} \mathrm{O}_{3}$ powder & 178.6 & 0.0 \\
$\mathrm{ATTM} / \gamma-\mathrm{Al}_{2} \mathrm{O}_{3}$ powder & 183.0 & 11.0 \\
Harshaw 0402T & 178.0 & 14.7 \\
\hline
\end{tabular}

Table 4.1: Molybdenum Content

Temperature-programmed reduction (TPR) is a technique in which reducible surface species are detected as peaks after they react with the reducing gas (usually $\mathrm{H}_{2}$ ). During the reduction, the loss of sulfur or oxygen atoms associated with $\mathrm{Mo}$, as $\mathrm{H}_{2} \mathrm{~S}$ or $\mathrm{H}_{2} \mathrm{O}$, creates anion vacancies. Therefore, TPR profiles contain information which provides clues to the nature of the starting catalyst. The effect of pretreatment on LTOC and TPR for supported catalyst decomposed by $\mathrm{ATTM} / \mathrm{Al}_{2} \mathrm{O}_{3}$ was investigated in this dissertation.

\subsubsection{Analysis of TPR Data}

For unsupported ATTM, Kalthod and Weller found that the molybdenum sulfide formed by thermal decomposition of ATTM in He at $450^{\prime \prime} \mathrm{C}$ contained excess sulfur ( $\mathrm{S} / \mathrm{Mo}=2.3$ ). Heating in $\mathrm{H}_{2}$ was required to remove excess sulfur and generate oxygen chemisorption sites. Kalthod and Weller [17] observed two $\mathrm{H}_{2} \mathrm{~S}$ peaks during TPR at about $180^{\circ} \mathrm{C}$ and $380^{\circ} \mathrm{C}$ for the unsupported ATTM catalyst.

The TPR profiles for the flash-decomposed and $10^{\circ} \mathrm{C} / \mathrm{min}$-decomposed supported ATTM samples are shown in Figure 4.1. Two $\mathrm{H}_{2} \mathrm{~S}$ peaks were observed during TPR. However, in contrast to unsupported ATTM, only one peak was observed at a temperature of $450^{\circ} \mathrm{C}$ as shown in Figure 4.2. For supported ATTM, TPR had to be continued up to a temperature of $550^{\circ} \mathrm{C}$ (Figure 4.1), in order to obtain two distinct peaks of $\mathrm{H}_{2} \mathrm{~S}$. Consequently, the peak 
temperatures for supported catalyst were about $380^{\circ} \mathrm{C}$ and $530^{\circ} \mathrm{C}$, and these were much higher than the corresponding values of about $180^{\circ} \mathrm{C}$ and $380^{\circ} \mathrm{C}$ for unsupported ATTM. The TPR profiles also showed that the $10^{\circ} \mathrm{C} / \mathrm{min}$-decomposed sample had a higher first peak than the flash decomposed sample, but the second peak was roughly the same height. This behavior is similar to what was observed for unsupported ATTM [17].

Various explanations exist for the two peaks observed during TPR. For unsupported ATTM, Kalthod et al. [16] proposed that the first and second TPR peaks corresponds to the loss of excess sulfur from the surface and bulk, respectively, based on BET measurements. Hall [13] has suggested that two different species co-exist in the catalyst, viz the tetrahedral species in smaller amounts together with the dominant octahedral species. Alternatively, it is possible that hydrogen is consumed in two steps. Laine et al. [23] carried out studies on Ni-Co-Mo catalysts supported on silica. They also observed a two-peak profile in the non-promoted samples. They suggested that the first peak $\left(575^{\circ} \mathrm{C}\right)$ may be assigned to dispersed polymolybdates linked to the silica surface and the second peak $\left(655^{\circ} \mathrm{C}\right)$ may be assigned to bulk $\mathrm{MoO}_{3}$. However, it is very difficult to compare TPR of molybdenum sulfide $\left(\mathrm{MoS}_{2}\right)$ and $\mathrm{MoO}_{3}$ supported catalysts. It therefore appears that there is no single, simple explanation that describes this phenomenon.

\subsubsection{Effect of Reduction Temperature}

The effect of reduction temperature during TPR in $\mathrm{H}_{2}$ on supported ATTM samples pretreated by temperature-programmed decomposition in helium is shown in Table 4.2. BET area, $\mathrm{H}_{2} \mathrm{~S}$ evolution and LTOC were measured at the end of the first and second TPR peaks.

Comparison of BET areas shows that the area reduction was only slight, suggesting that sintering was not a problem. Studies on the thermal behavior of shell catalysts by Duncombe and Weller [7] showed that no sintering and redistribution took place for MoAlumina catalysts up to $625^{\circ} \mathrm{C}$. This is because the catalyst is stabilized by interaction with the support. For unsupported ATTM, Kalthod and Weller observed that sintering started 


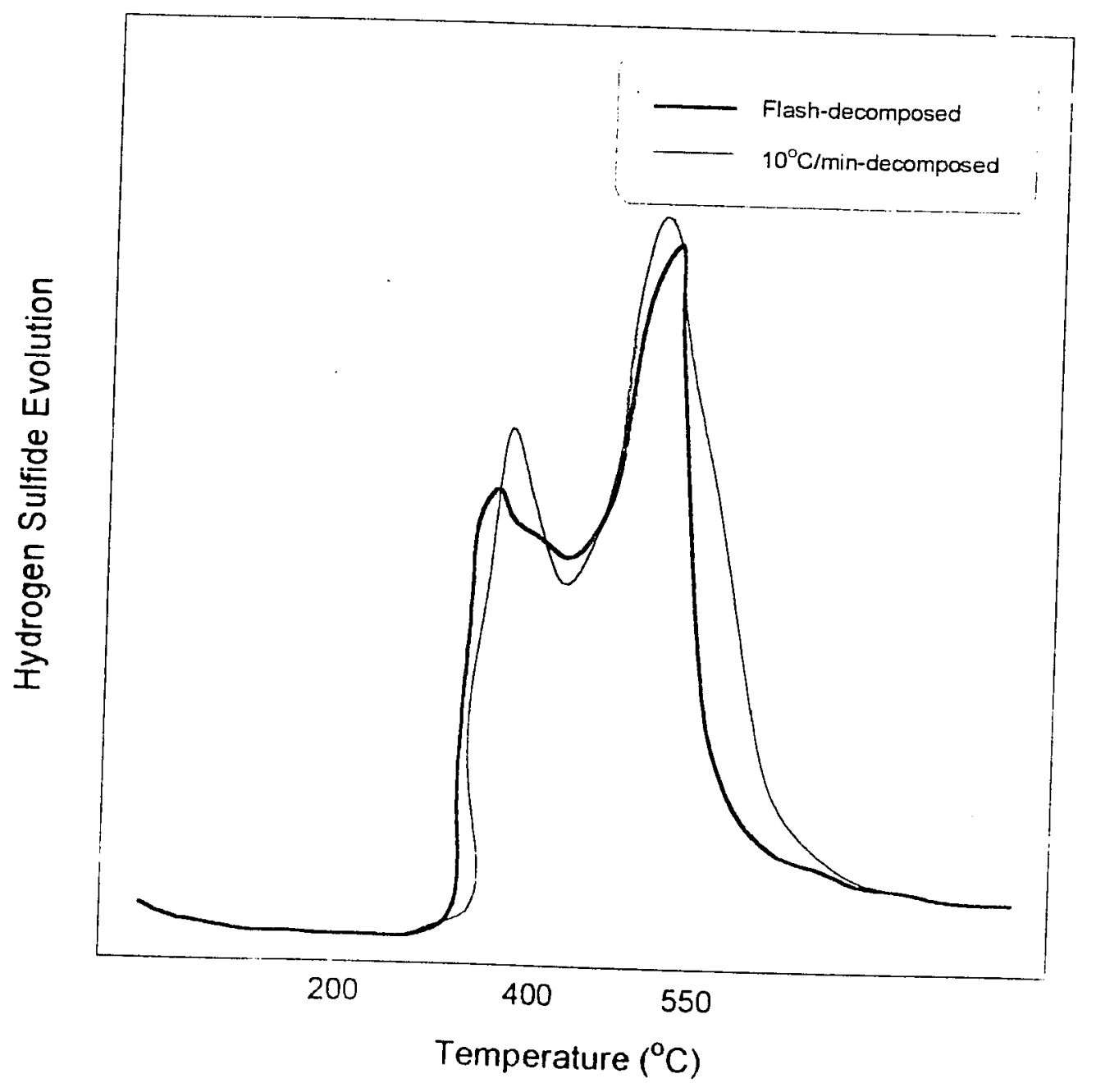

Figure 4.1: Temperature-programmed reduction profile for $\mathrm{MoS}_{y} / \mathrm{Al}_{2} \mathrm{O}_{3}$. Catalyst Weight $=0.2 \mathrm{~g}$. Final temperature $=550^{\circ} \mathrm{C}$ 


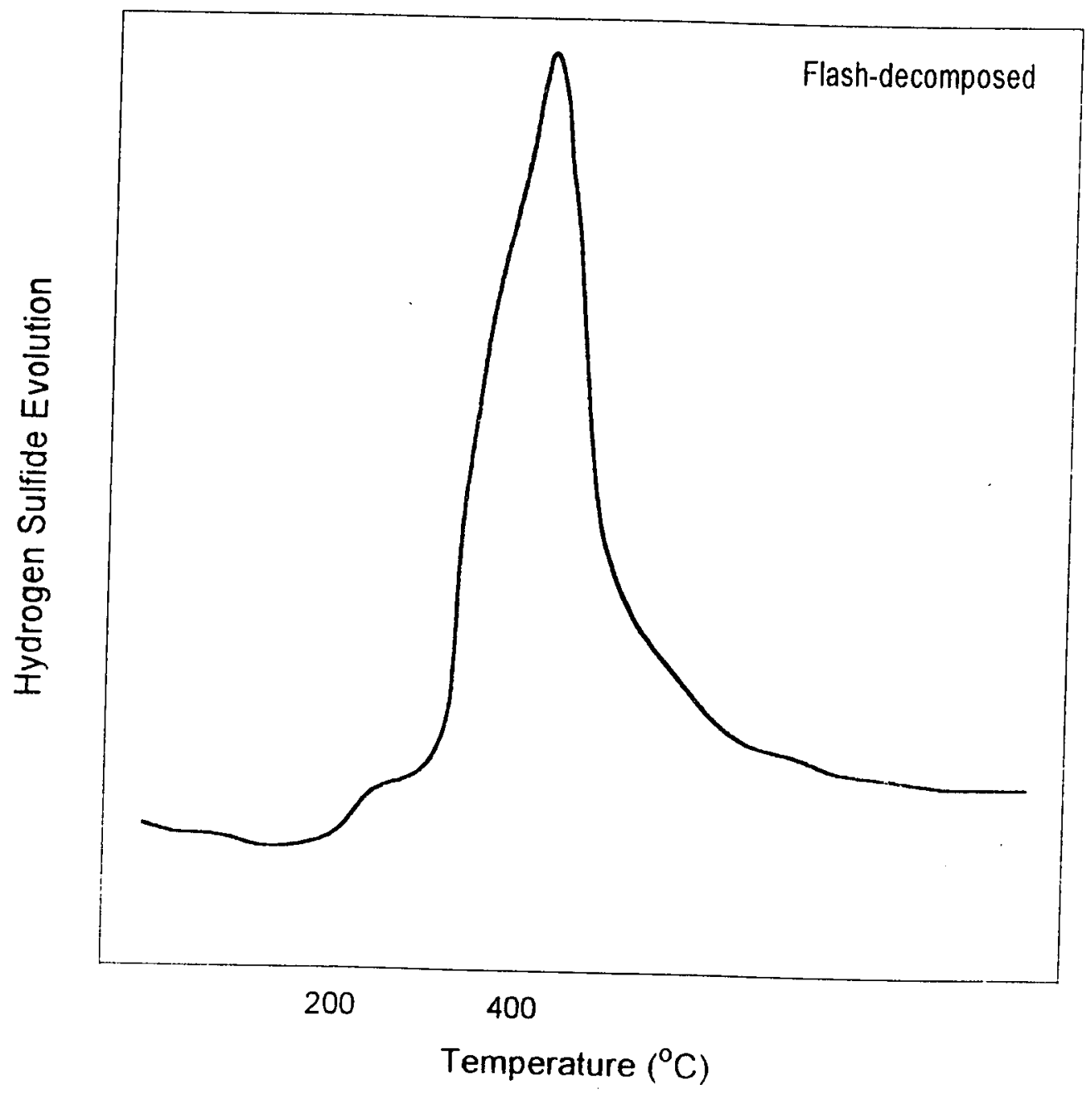

Figure 4.2: Temperature-programmed reduction profile for $\mathrm{MoS}_{y} / \mathrm{Al}_{2} \mathrm{O}_{3}$. Catalyst Weight $=0.2$ g. Final temperature $=450^{\circ} \mathrm{C}$ 


\begin{tabular}{|c|c|c|c||}
\hline $\begin{array}{c}\text { Reduction } \\
\text { Temperature }\left({ }^{\circ} \mathrm{C}\right)\end{array}$ & $\begin{array}{c}\mathrm{H}_{2} \mathrm{~S} \\
\text { Evolution }(\mathrm{mL} / \mathrm{g})\end{array}$ & $\begin{array}{c}\text { BET Area } \\
\left(\mathrm{m}^{2} / \mathrm{g}\right)\end{array}$ & $\begin{array}{c}\text { LTOC } \\
(\mathrm{mL} / \mathrm{g})\end{array}$ \\
\hline 20 & 0.0 & 183.0 & - \\
420 & 9.36 & 175.4 & 0.68 \\
550 & 21.14 & 174.9 & 1.42 \\
\hline
\end{tabular}

Table 4.2: Effect of Reduction Temperature

after heating in $\mathrm{H}_{2}$ beyond the first TPR peak, that is, at temperatures above $250^{\circ} \mathrm{C}$, indicating that the second peak involved removal of excess sulfur from the bulk. They also observed that sintering was severe at temperatures above $450^{\circ} \mathrm{C}$.

Kalthod and Weller reported that for unsupported ATTM, the absolute values of LTOC showed a maximum at $400^{\circ} \mathrm{C}$. This was attributed to a balance between two opposing effects on LTOC with increasing temperature: increase in sulfur removal, and loss of surface area by sintering. Contrary to unsupported ATTM, the LTOC values for supported ATTM increase with increasing in temperature up to $550^{\circ} \mathrm{C}$. This is most likely due to the low extent of sintering coupled with the creation of more anion vacancies with increase in temperature. The presence of the support clearly has a stabilizing effect on the surface structure of the supported material.

\subsubsection{Effect of Sample Size}

The effect of two different sample sizes, $0.1 \mathrm{~g}$ and $0.2 \mathrm{~g}$, on catalyst performance was studied. The samples were decomposed at a rate of $10^{\circ} \mathrm{C} / \mathrm{min}$, and then subjected to TPR. The $\mathrm{H}_{2} \mathrm{~S}$ evolution and LTOC values are shown in Table 4.3.

It is observed that the smaller sample had a higher specific $\mathrm{H}_{2} \mathrm{~S}$ evolution during TPR. Since removal of sulfur results in an increase in anion vacancies, the LTOC value for smaller samples was also observed to be higher. The larger $\mathrm{H}_{2} \mathrm{~S}$ evolution for smaller samples may 


\begin{tabular}{||c|c|c||}
\hline Sample Size $(\mathrm{g})$ & $\mathrm{H}_{2} \mathrm{~S}$ evolution $(\mathrm{mL} / \mathrm{g})$ & LTOC $(\mathrm{mL} / \mathrm{g})$ \\
\hline 0.1 & 27.65 & 2.35 \\
0.2 & 21.14 & 1.42 \\
\hline
\end{tabular}

Table 4.3: Effect of Sample Size

be attributed to a larger amount of excess sulfur following thermal decomposition in helium. This has been observed for unsupported ATTM as well [16].

\subsection{Correlation of Pretreatment, LTOC and Activity}

There is considerable uncertainty regarding the nature of active sites for molybdenum sulfide catalysts, particularly in regard to the identification of functionally different sites for different reactions. The catalytic sites in the sulfide form of $\mathrm{Mo} / \mathrm{Al}_{2} \mathrm{O}_{3}$ catalysts are believed to consist of coordinately unsaturated Mo ions or the associated anion vacancies $[13,27,55]$.

For hydrogenation and hydrogenolysis reactions, active sites are believed to be located at the edges of the $\mathrm{MoS}_{2}$-like slabs, where Mo atoms are incompletely coordinated with $\mathrm{S}^{2-}$ ions [41]. These sites are also found to adsorb molecules such as $\mathrm{CO}, \mathrm{NO}$ and oxygen. The selective chemisorption of oxygen has been extensively used to characterize $\mathrm{Mo} / \mathrm{Al}_{2} \mathrm{O}_{3}$ catalysts both in the sulfide and oxide forms $[34,52]$. The amount of oxygen or NO chemisorption has been found to correlate with the catalytic activity for hydrogenation $[2,24,25]$ and hydrogenolysis $[28,30,51,58]$.

In the case of supported molybdenum sulfide prepared by the decomposition of ATTM, it is possible that the molybdenum sulfide still exists as two dimensional slabs, and the active sites are still located at the edges of slabs, especially at low loadings. At higher Mo loadings, clusters of slabs are probably formed.

The study of correlation of pretreatment, LTOC and activities provides the information 
regarding the active sites and surface structure for the novel catalyst. The results are discussed in the following sections.

\subsubsection{Thiophene Hydrogenolysis}

Thiophene hydrodesulfurization (HDS) has been widely used as a model reaction for testing the activity of hydroprocessing catalysts. The reaction is based on the following equation:

$$
2 \mathrm{C}_{4} \mathrm{H}_{4} \mathrm{~S}+7 \mathrm{H}_{2} \longrightarrow 2 \mathrm{H}_{2} \mathrm{~S}+\mathrm{C}_{4} \mathrm{H}_{8}+\mathrm{C}_{4} \mathrm{H}_{10}
$$

The reactant can be carried into the reactor either continuously or in pulses. In the continuous method, thiophene in a carrier gas stream passes through the reactor continuously and the steady state activity of the catalyst is measured. In the pulse method, pulses of thiophene are injected into the carrier gas periodically. The catalyst activity is measured at its initial state and this technique offers a means of rapid screening of catalyst activity.

\section{Continuous Method}

Catalyst pretreatment has effects on catalyst morphology and therefore has effects on catalyst activities. In this study, the activity for thiophene hydrodesulfurization of a supported ATTM catalyst subjected to either flash decomposition or temperature-programmed decomposition followed by temperature-programmed reduction, were compared. The results are shown in Table 4.4 and Figure 4.3. In a separate experiment, it was ensured that the concentration of thiophene in the feed to the reactor (outlet from saturator) remained constant over the duration of the experiment. It was found that the activity of the flash-decomposed sample was slightly lower than the activity of the temperature program decomposed sample. The effect of reduction temperature on catalyst activity is shown in Figure 4.4 which compares the activities of a supported ATTM catalyst subjected to $10^{\circ} \mathrm{C} / \mathrm{min}$ thermal decomposition followed by temperature-programmed reduction to $420^{\circ} \mathrm{C}$ and $550^{\circ} \mathrm{C}$, respectively. The activity of the catalyst after the second TPR peak $\left(550^{\circ} \mathrm{C}\right)$ was clearly higher.

LTOC values and thiophene IIDS activity for different pretreatments are compared 


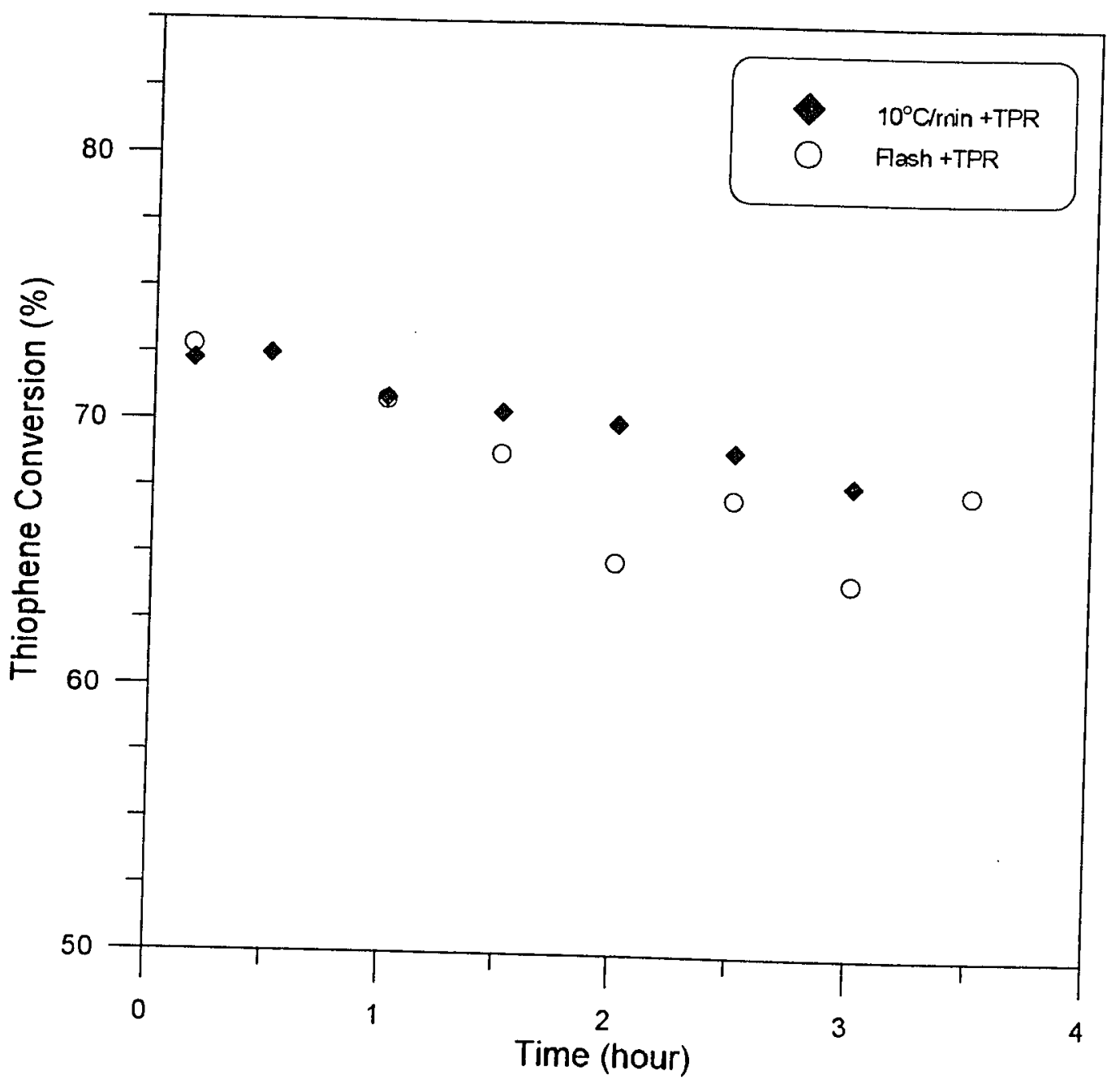

Figure 4.3: Effect of thermal decomposition heating rate on HDS activity. Continuous method. Catalyst Weight $=0.2 \mathrm{~g}$. Catalyst prepared by flash and $10^{\circ} \mathrm{C} / \mathrm{min}$ thermal decomposition of ATTM in He followed by TPR 


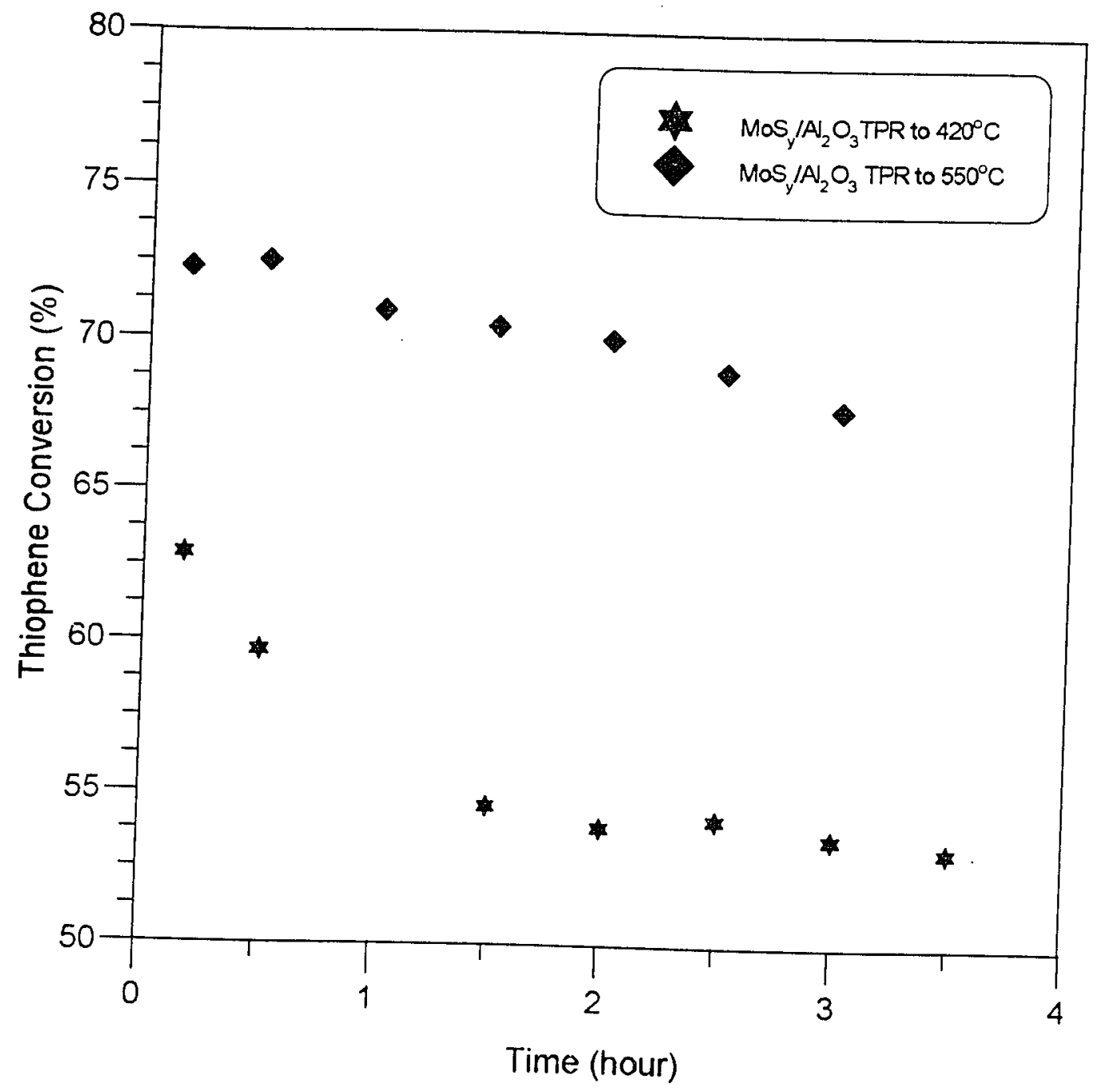

Figure 4.4: Effect of reduction temperature on HDS activity. Continuous method. Catalyst Weight $=0.2 \mathrm{~g}$. Catalyst prepared by $10^{\circ} \mathrm{C} / \mathrm{min}$ decomposition of ATTM followed by TPR to $420^{\circ} \mathrm{C}$ and $550^{\circ} \mathrm{C}$. 


\begin{tabular}{||l|l|c|c||}
\hline Catalyst & Pretreatment & LTOC $(\mathrm{mL} / \mathrm{g})$ & Ave. Conv.(\%) \\
\hline $\mathrm{MoS}_{y} / \mathrm{Al}_{2} \mathrm{O}_{3}$ & Hydrogen Reduction & 0.75 & 71.3 \\
$\mathrm{MoS}_{y} / \mathrm{Al}_{2} \mathrm{O}_{3}$ & $10^{\circ} \mathrm{C} /$ min decomposition+TPR $\left(550^{\circ} \mathrm{C}\right)$ & 1.42 & 70.4 \\
$\mathrm{MoS}_{y} / \mathrm{Al}_{2} \mathrm{O}_{3}$ & Flash decomposition+TPR & 1.31 & 68.0 \\
$\mathrm{MoS}_{y} / \mathrm{Al}_{2} \mathrm{O}_{3}$ & $10^{\circ} \mathrm{C} /$ min decomposition+TPR $\left(420^{\circ} \mathrm{C}\right)$ & 0.68 & 56.0 \\
\hline
\end{tabular}

Table 4.4: Effect of Pretreatment on Thiophene Conversion and LTOC

in Table 4.4. All the experiments were repeated in order to ensure that the values were reproducible. There appears to be a direct correlation between LTOC and thiophene activity except in the case of a catalyst sample prepared by hydrogen reduction. The reason for the lower LTOC value for a catalyst sample prepared by reduction in $\mathrm{H}_{2}$ alone is not clear. Contrary to unsupported ATTM, the $10^{\circ} \mathrm{C} / \mathrm{min}$-decomposed sample showed a higher LTOC than the flash-decomposed sample. Tauster et al. [47] have proposed that oxygen is a selective chemisorbate for edge sites. If this hypothesis is valid, the gradually heated sample may exhibit a higher proportion of edge sites than the flash-heated sample.

Reductive sulfiding in $\mathrm{H}_{2} \mathrm{~S} / \mathrm{H}_{2}$ is a common method of activating conventional oxide molybdenum catalysts. It has been found this pretreatment affects the catalyst morphology $[16,47]$. The effect of reductive sulfiding on unsupported ATTM was studied by Kalthod et al. $[16]$ and the results are shown in Table 4.5. The propylene HYD activity for the catalyst pretreated by reductive sulfiding has a specific reaction rate $\mathrm{k}_{s}$ equal to $0.33 \times 10^{9}$ $\mathrm{mol} / \mathrm{cm}^{2} \mathrm{sec}$, which is similar to that for a catalyst sample subjected to TPR at $250^{\circ} \mathrm{C}[16]$. This means for unsupported ATTM, the existence of $\mathrm{H}_{2} \mathrm{~S}$ in reduction stream inhibits the loss of sulfur and has the effect of giving the catalyst a surface structure and activity similar to the catalyst with excess sulfur in bulk. Kalthod suggested that due to the existence of excess sulfur, a certain fraction of the anion vacancies at the surface may not be associated with Mo atoms, thus the catalyst may possess a low activity. For a sample prepared by 


\begin{tabular}{||l|c|c||}
\hline Pretreatment & $\begin{array}{r}\text { Unsupported ATTM } \\
\mathbf{k}_{s}\left(\times 10^{9} \mathrm{~mol} / \mathrm{cmsec}\right)\end{array}$ & $\begin{array}{c}\text { Supported ATTM } \\
\text { Conv. (\%) }\end{array}$ \\
\hline $\begin{array}{l}10^{\circ} \mathrm{C} / \text { min decomposition }+ \\
\text { reductive sulfiding }\end{array}$ & 0.33 & 13.9 \\
\hline $\begin{array}{l}10^{\circ} \mathrm{C} / \text { min decomposition }+ \\
\text { reductive sulfiding+TPR }\end{array}$ & 4.6 & 16.2 \\
\hline $10^{\circ} \mathrm{C} /$ min decomposition+TPR & 7.1 & 16.0 \\
\hline
\end{tabular}

Table 4.5: Effect of Reductive Sulfiding on Catalyst Activity

reductive sulfiding followed by further heating in $\mathrm{H}_{2}$ to $550^{\circ} \mathrm{C}$, the specific reaction rate $\mathrm{k}_{s}$ increased to $4.6 \times 10^{9} \mathrm{~mol} / \mathrm{cm}^{2} \mathrm{sec}$, suggestion that heating in $\mathrm{H}_{2}$ causes a further loss of $\mathrm{H}_{2} \mathrm{~S}$ and therefore creates more active sites. For a sample pretreated by TPR in $\mathrm{H}_{2}$ (without reductive sulfiding), $\mathrm{k}_{\mathrm{s}}$ was $7.1 \times 10^{9} \mathrm{~mol} / \mathrm{cm}^{2} \mathrm{sec}$, which was higher than the $\mathrm{k}_{\mathrm{s}}$ for the sample subjected to reductive sulfiding followed by TPR. It suggests that the morphology difference caused by reductive sulfiding remains even after further heating in pure $\mathrm{H}_{2}$.

The effect of reductive sulfiding on the supported catalyst thiophene HDS activity is also shown in Table 4.5. For the catalyst pretreated by reductive sulfiding, the thiophene conversion increased by further heating in pure $\mathrm{H}_{2}$, but the amount of increase is not as much as for unsupported ATTM. The thiophene conversions were almost the same for the catalysts subjected to TPR and reductive sulfiding followed by TPR. This suggests that the morphological difference caused by reductive sulfiding after reheating in pure $\mathrm{H}_{2}$ for supported catalysts is not as predominant as for unsupported ATTM.

It is interesting to note that for the same pretreatment, for example, $10^{\circ} \mathrm{C} / \mathrm{min}$ decomposition followed by TPR, the supported ATTM catalyst had a much higher LTOC (1.42 mL/g supported ATTM, or $10.32 \mathrm{~mL} / \mathrm{g}$ ATTM), than the unsupported ATTM catalyst, $(0.166 \mathrm{~mL} / \mathrm{g})[17]$. 
The effect of catalyst preparation technique on thiophene conversion is shown in Figure 4.5. The $\mathrm{MoS}_{y} / \mathrm{Al}_{2} \mathrm{O}_{3}$ catalyst prepared by the decomposition of ATTM in hydrogen alone showed the highest thiophene conversion. The Harshaw $0402 \mathrm{~T}$ catalyst prepared by reductive sulfiding had an intermediate conversion and the conventional oxide catalyst with the same Mo loading as the $\mathrm{MoS}_{y} / \mathrm{Al}_{2} \mathrm{O}_{3}$ catalyst and prepared by reductive sulfiding, was the least active. Figure 4.6 compares the activity of the Harshaw catalyst with the activity of the supported ATTM catalyst, in which both catalysts were subjected to hydrogen reduction. The $\mathrm{MoS}_{y} / \mathrm{Al}_{2} \mathrm{O}_{3}$ catalyst had the higher activity compared to the Harshaw catalyst. The results are summarized in Table 4.6.

The catalyst prepared by $\mathrm{H}_{2}$ reduction of $\mathrm{ATTM} / \mathrm{Al}_{2} \mathrm{O}_{3}$ has much higher HDS activity than conventional oxide catalysts are mainly due to the following reasons:

During the reductive sulfiding, conventional oxide catalysts might have not been completely converted into sulfides, a part of the oxide layer in the bulk remaining intact, whereas the catalyst prepared by thermal decomposition of thiosalt contain the Mo-S-Mo bonds only. Since the sulfur atom is a greater electron donor than a oxygen atom, it would have increased the electron density on the molybdenum ions on the surface of the catalysts created during reduction. The higher electron density might have resulted in the enhanced electron donation to the thiophene molecule causing greater C-S bond rupture. This would result in increasing the activity per site for HDS reaction.

An important assumption made by this dissertation is that a lower valence state of Mo will result in more anion vacancies leading to higher catalyst activities. Previous studies by Vasudevan and Weller [54] have shown that the catalyst prepared by $\mathrm{H}_{2}$ reduction of ATTM has a valence state lower than 4 , which is lower than the valence state of Mo(IV) in $\mathrm{MoS}_{2}-\mathrm{MoO}_{2}$ catalyst prepared by reductive sulfiding of conventional oxides. The above comparison strongly supports this hypothesis. 


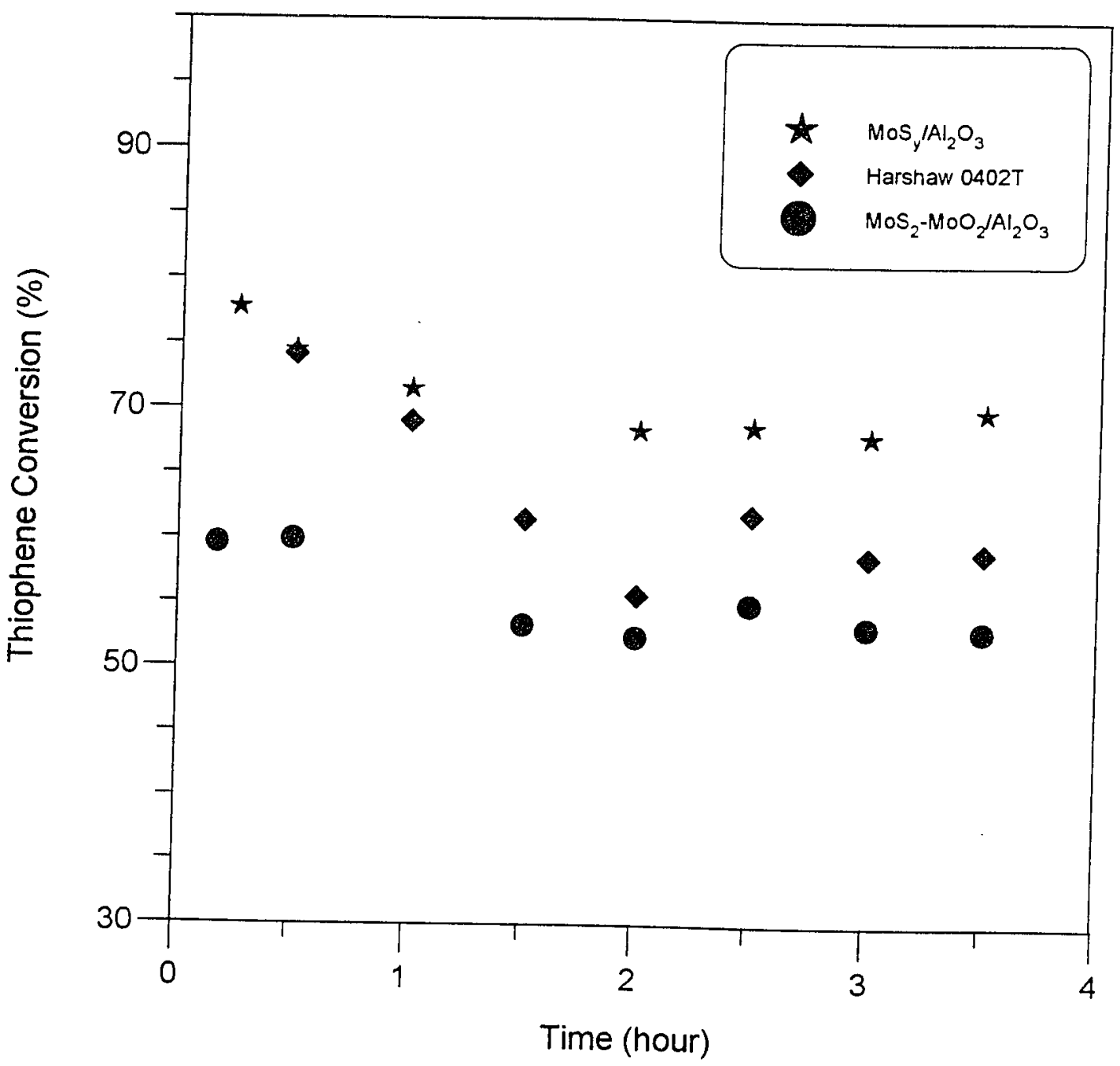

Figure 4.5: Effect of catalyst preparation on HDS activity. Continuous method. Catalyst Weight $=0.2 \mathrm{~g}$. Catalyst prepared by $\mathrm{H}_{2}$ reduction of $\mathrm{ATTM}$, and reductive sulfiding of $\mathrm{MoO}_{3}$ and Harshaw 0402T followed by TPR. 


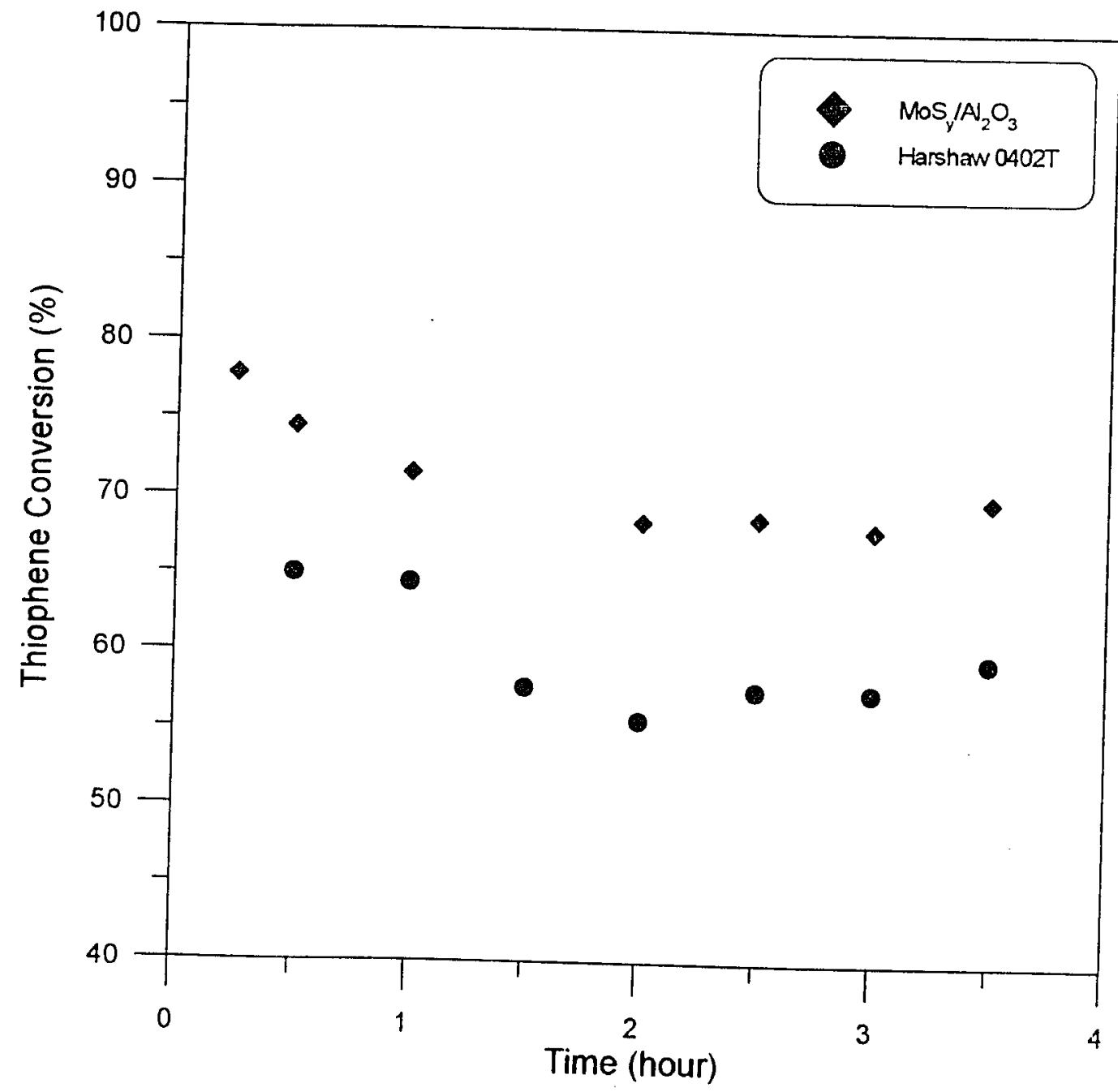

Figure 4.6: Effect of catalyst preparation on HDS activity. Continuous method. Catalyst Weight $=0.2 \mathrm{~g}$. Catalysts prepared by $\mathrm{H}_{2}$ reduction of ATTM and Harshow $0402 \mathrm{~T}$. 


\begin{tabular}{||l|c|c||}
\hline Catalyst & $\begin{array}{c}\text { Pretreatment } \\
\mathrm{H}_{2} \mathrm{~S} / \mathrm{H}_{2}+\mathrm{TPR}\end{array}$ & $\begin{array}{c}\text { Pretreatment } \\
\mathrm{H}_{2} \text { Reduction }\end{array}$ \\
\cline { 2 - 4 } & Average Conversion(\%) & Average Conversion(\%) \\
\hline $\mathrm{MoS}_{y} / \mathrm{Al}_{2} \mathrm{O}_{3}$ & $70.4^{1}$ & 71.3 \\
$\mathrm{MoO}_{3} / \mathrm{Al}_{2} \mathrm{O}_{3}$ & 55.0 & - \\
$\mathrm{Harshaw} \mathrm{0402 \textrm {T }}$ & 66.5 & 59.8 \\
\hline
\end{tabular}

Table 4.6: Effect of Catalyst Preparation on Thiophene Conversion

${ }^{1}$ Temperature-programmed decomposition + TPR

\section{Comparison of Continuous and Pulse Methods}

The microcatalytic pulse method was first used by Emmett and co-workers [21]. The advantage of this method is that the reactants interact with the catalyst in its initial state. Since the state of the fresh catalyst can be characterized by a variety of physicochemical methods, the information from the pulsed microcatalytic reactor can aid in understanding the relationship between catalyst structure and its activity and selectivity. In the pulse method, pulses of reactant (gases, or liquids vaporized in a heated injection port) are periodically injected into a carrier gas flowing through a small amount of catalyst and then into a gas chromatograph for analysis. In this study, the thiophene hydrogenolysis activity of a supported ATTM catalyst was measured by a pulse method, as well as by a continuous method. Comparison of the two methods will be discussed.

The ATTM $/ \mathrm{Al}_{2} \mathrm{O}_{3}$ catalysts subjected to different pretreatments were cooled to $400^{\circ} \mathrm{C}$ and total of 10 successive injections of thiophene at $2 \mu \mathrm{L}$ were made for each catalyst. The effect of pretreatment on catalyst activity is shown in Figures 4.7 and 4.8. Figure 4.7 compares the activity of the supported ATTM catalyst subjected to either flash decomposition or temperature-programmed decomposition, followed by TPR in both cases. The lines present a least squares fit of the data. In spite of the scatter, it appears that the activity 


\begin{tabular}{||l|c|cc||}
\hline Catalyst & Pretreatment & \multicolumn{2}{|c||}{ Thiophene Ave. Conv. (\%) } \\
& Continuous & Pulse \\
\hline $\mathrm{MoS}_{y} / \mathrm{Al}_{2} \mathrm{O}_{3}$ & Hydrogen Reduction & 71.3 & 87.0 \\
$\mathrm{MoS}_{y} / \mathrm{Al}_{2} \mathrm{O}_{3}$ & $10^{\circ} \mathrm{C} /$ min-decomposed+TPR $\left(550^{\circ} \mathrm{C}\right)$ & 70.4 & 83.0 \\
$\mathrm{MoS}_{y} / \mathrm{Al}_{2} \mathrm{O}_{3}$ & Flash-decomposed+TPR & 68.0 & 80.6 \\
$\mathrm{MoS}_{y} / \mathrm{Al}_{2} \mathrm{O}_{3}$ & $10^{\circ} \mathrm{C} /$ min-decomposed+TPR $\left(420^{\circ} \mathrm{C}\right)$ & 56.0 & 72.3 \\
\hline
\end{tabular}

Table 4.7: Comparison of Pulse and Continuous Method-Effect of Pretreatment

of the flash-decomposed sample is slightly lower than the activity of $10^{\circ} \mathrm{C} / \mathrm{min}$-decomposed sample. Figure 4.8 compares the activity of a supported ATTM catalyst subjected to $10^{\circ} \mathrm{C} / \mathrm{min}$ decomposition followed by TPR to $420^{\circ} \mathrm{C}$ and $550^{\circ} \mathrm{C}$, corresponding to the first and second $\mathrm{H}_{2} \mathrm{~S}$ peak, respectively. The catalyst activity after the second TPR peak is clearly higher. Comparison of catalyst activities measured by the pulse and the continuous methods is shown in Table 4.7. It was found that for both methods the activity of the flashdecomposed sample was lower than the activity of the $10^{\circ} \mathrm{C} / \mathrm{min}$-decomposed sample. The activity of the catalyst subjected to a temperature-programmed decomposition followed by TPR to $550^{\circ} \mathrm{C}$ is higher than that to $420^{\circ} \mathrm{C}$.

The effect of catalyst preparation technique on thiophene conversion for pulse method is shown in Figure 4.9, the comparison of pulse and continuous methods is shown in Table 4.8. For both methods, the $\mathrm{MoS}_{y} / \mathrm{Al}_{2} \mathrm{O}_{3}$ catalyst prepared by the decomposition of ATTM in hydrogen alone showed the highest thiophene conversion. The Harshaw 0402T catalyst prepared by reductive sulfiding had an intermediate conversion and the conventional oxide catalyst was the least active. The activities of the Harshaw catalyst and the supported ATTM catalyst, in which both catalysts were subjected to hydrogen reduction, are also compared in Table 4.8. The ATTM $/ \mathrm{Al}_{2} \mathrm{O}_{3}$ catalyst had the higher activity compared to the Harshaw catalyst for both methods (Figure 4.10). 


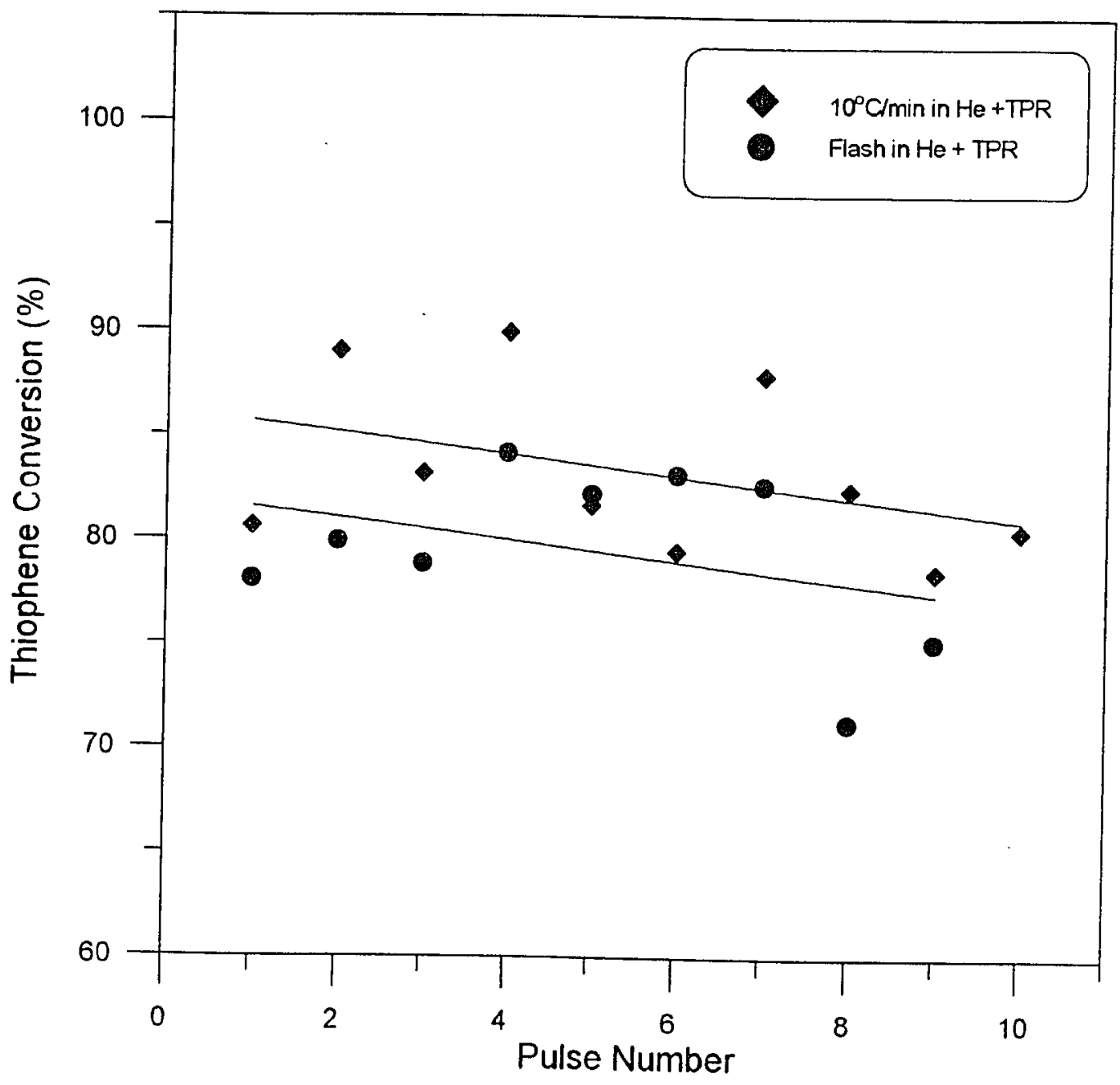

Figure 4.7: Effect of thermal decomposition heating rate on HDS activity. Pulse method. Catalyst Weight $=0.2 \mathrm{~g}$. Catalyst prepared by flash and $10^{\circ} \mathrm{C} / \mathrm{min}$ thermal decomposition of ATTM in He followed by TPR 


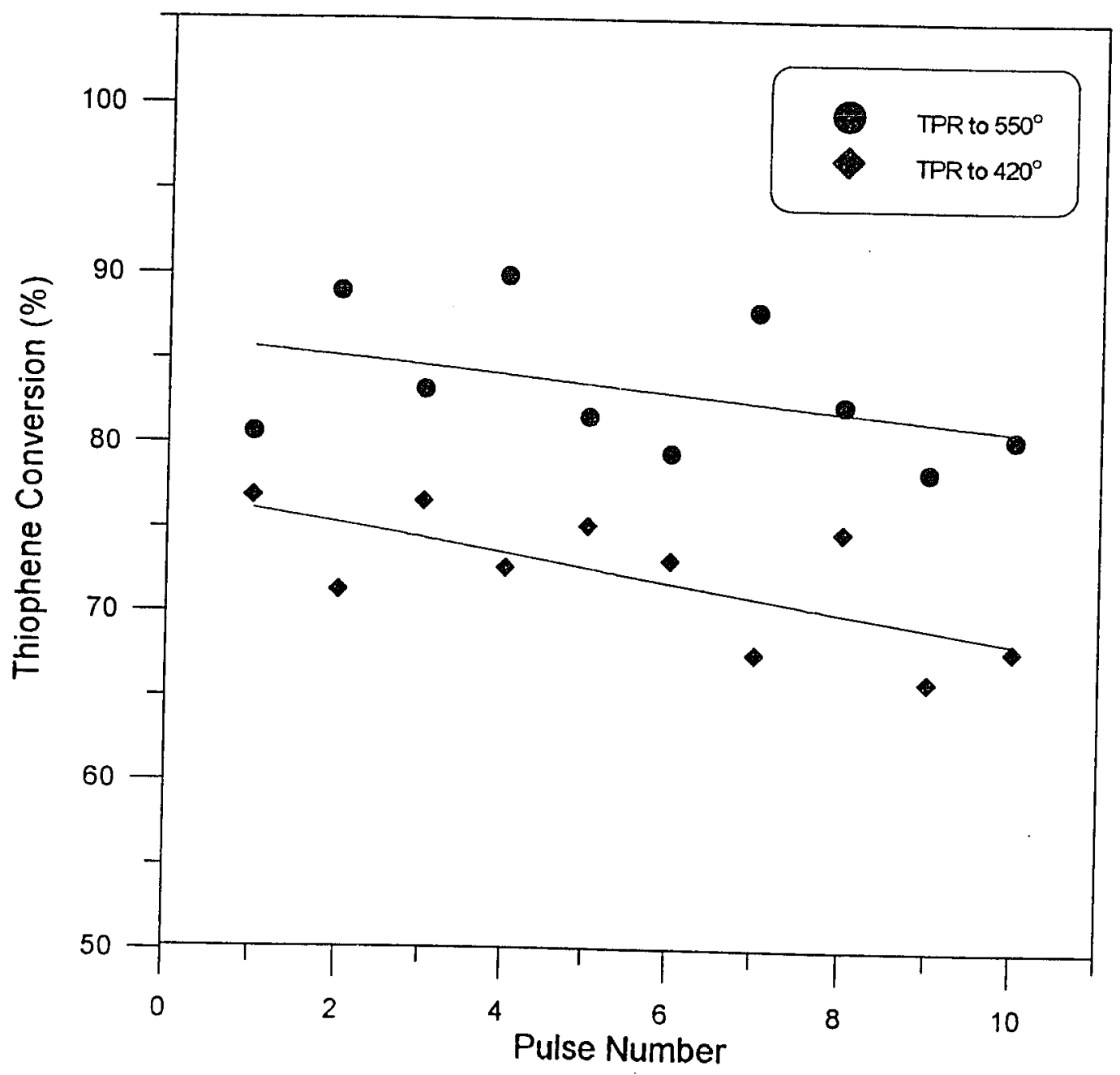

Figure 4.8: Effect of reduction temperature on HDS activity. Pulse method. Catalyst Weight $=0.2 \mathrm{~g}$. Catalyst prepared by $10^{\circ} \mathrm{C} / \mathrm{min}$ decomposition of ATTM followed by TPR to $420^{\circ} \mathrm{C}$ and $550^{\circ} \mathrm{C}$. 


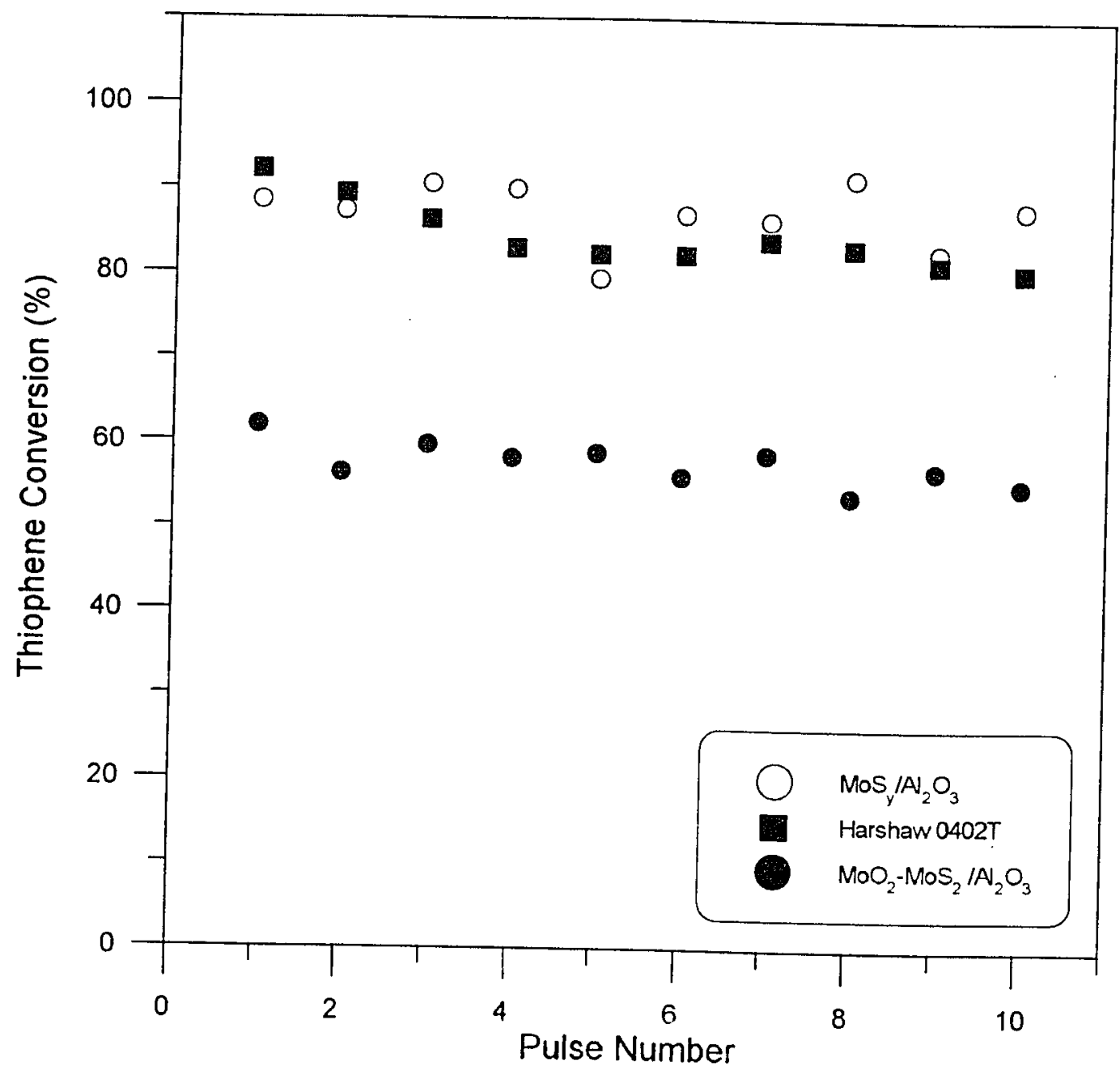

Figure 4.9: Effect of catalyst preparation on HDS activity. Pulse method. Catalyst Weight $=0.2 \mathrm{~g}$. Catalyst prepared by $\mathrm{H}_{2}$ reduction of ATTM, and reductive sulfiding of $\mathrm{MoO}_{3}$ and Harshaw $0402 \mathrm{~T}$ followed by TPR. 


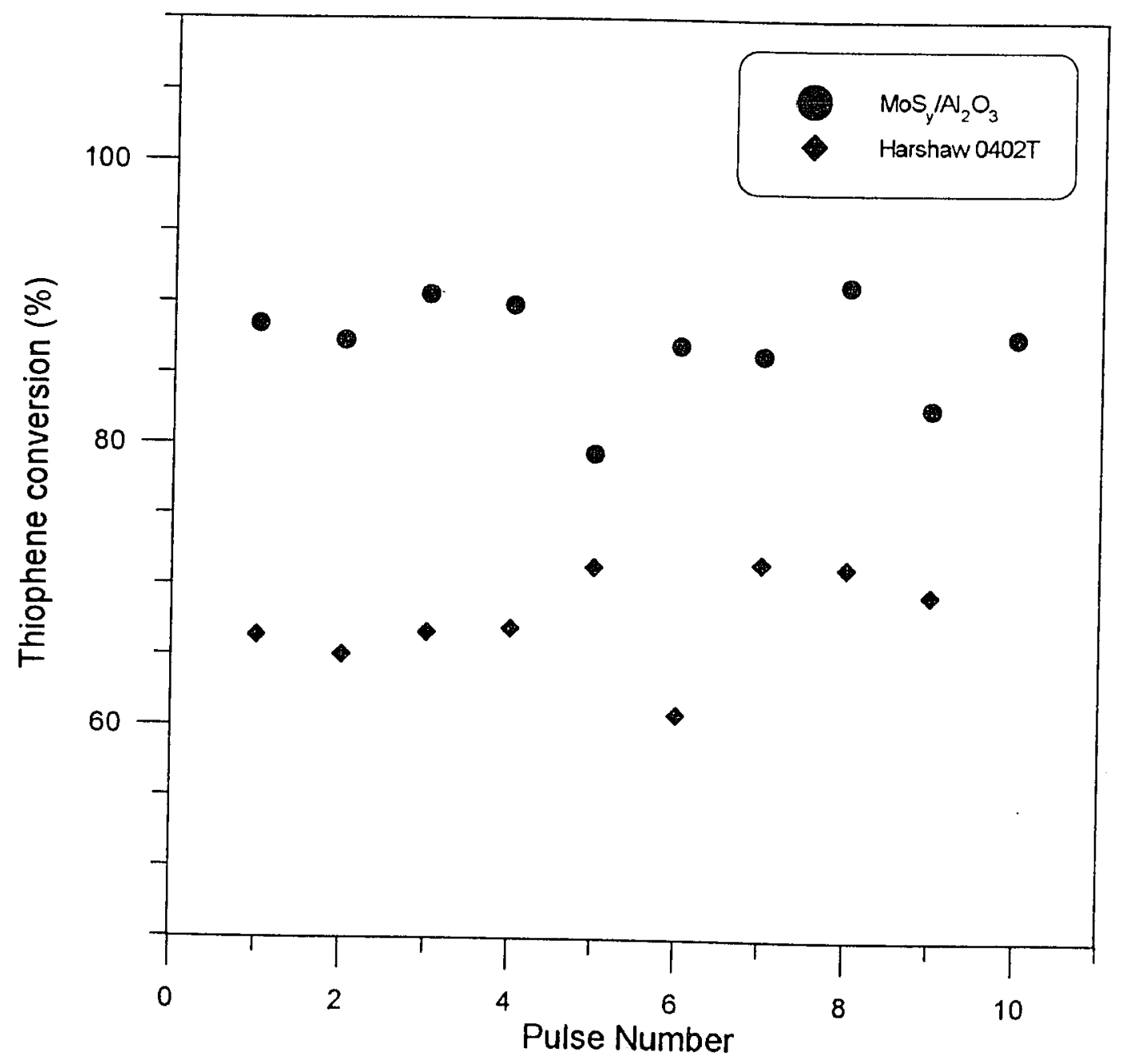

Figure 4.10: Effect of catalyst preparation on HDS activity. Pulse method. Catalyst Weight $=0.2$ g. Catalysts prepared by $\mathrm{H}_{2}$ reduction of ATTM and Harshow 0402T. 


\begin{tabular}{||l|cc|cc||}
\hline Catalyst & \multicolumn{2}{|c|}{ Pretreatment } & Pretreatment \\
& $\begin{array}{r}\mathrm{H}_{2} \mathrm{~S} / \mathrm{H}_{2}+\mathrm{TPR} \\
\text { Continuous }\end{array}$ & Pulse & Continuous & Pulse \\
\hline $\mathrm{MoS}_{y} / \mathrm{Al}_{2} \mathrm{O}_{3}$ & $70.4^{2}$ & - & 71.3 & 87.0 \\
$\mathrm{MoO}_{3} / \mathrm{Al}_{2} \mathrm{O}_{3}$ & 55.0 & 57.5 & - & - \\
Harshaw 0402T & 66.5 & 84.4 & 59.8 & 60.9 \\
\hline
\end{tabular}

Table 4.8: Comparison of Pulse and Continuous Method-Effect of Catalyst Preparation

2 Temperature-programmed decomposition + TPR

In the continuous reaction system, the conversion of thiophene reached a steady-state after 1 hour. Deactivation of the catalysts was not a problem since the difference between the activity of the $\mathrm{MoS}_{y} / \mathrm{Al}_{2} \mathrm{O}_{3}$ catalyst and the activities of the other catalysts remained fairly constant even after 3 hours. In the case of pulse method, a total of 10 successive injections of thiophene were made for each catalyst during 3 hour period. Reduction of conversion was observed with the introduction of each pulse.

For a pulse method, a typical gas chromatography signal integration curve for the separation of reaction products is shown in Figure 4.11. According to retention time calibration, the component elution order from the $\mathrm{GC}$ is $\mathrm{H}_{2} \mathrm{~S}$, followed by $\mathrm{C}_{4}$ components and unconverted thiophene, respectively. Unconverted thiophene peak appeared at retention time longer than 6 minutes.

Comparison of $\mathrm{H}_{2} \mathrm{~S}$ peak areas for Harshaw catalyst pretreated by $\mathrm{H}_{2}$ reduction and reductive sulfiding is listed in Table 4.9. It can be seen that the peak area of $\mathrm{H}_{2} \mathrm{~S}$ increased with every pulse during the reaction. For the catalyst which was subjected to $\mathrm{H}_{2}$ reduction only, the $\mathrm{H}_{2} \mathrm{~S}$ appeared to chemisorb with the catalyst initially, hence no peak or very small $\mathrm{H}_{2} \mathrm{~S}$ peaks were observed in the first couple of pulses. For the catalyst subjected to reductive sulfiding in $\mathrm{H}_{2} \mathrm{~S} / \mathrm{H}_{2}$, the $\mathrm{H}_{2} \mathrm{~S}$ peak appeared at the first injection and the effluent 


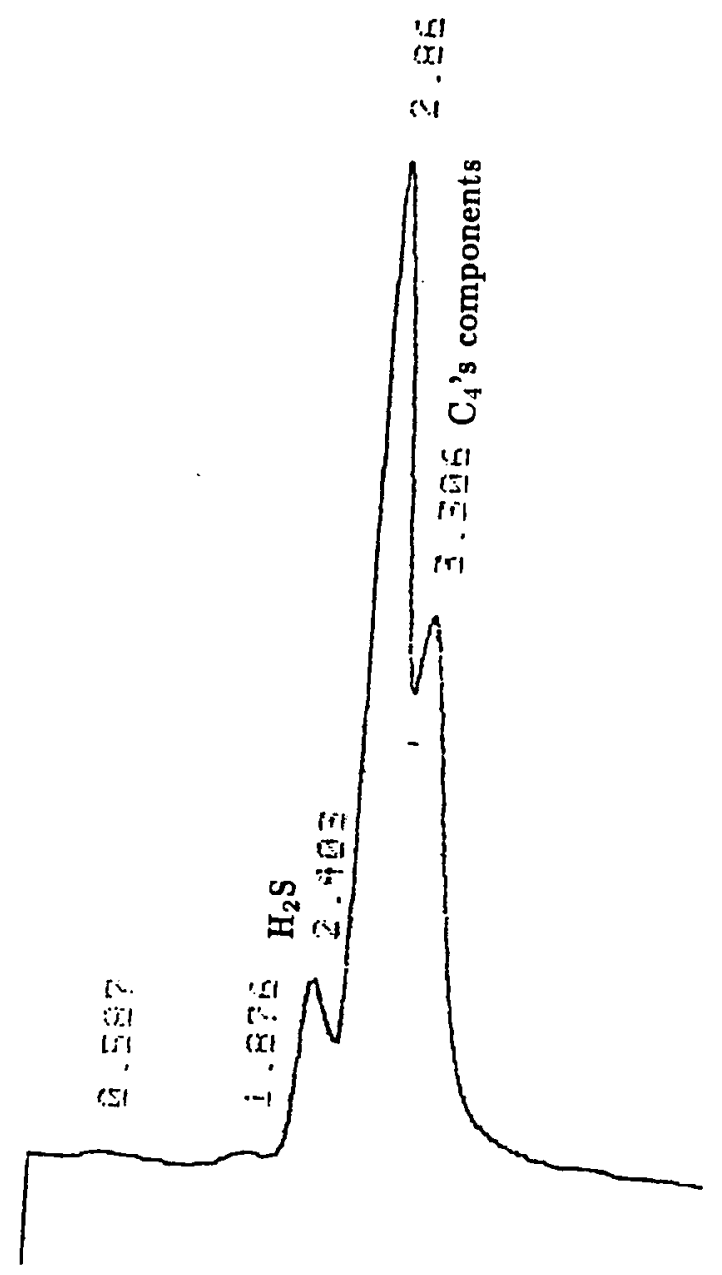

Figure 4.11: Separation of reaction products during thiophene HDS reaction. Pulse method. Catalyst Weight $=0.2 \mathrm{~g}$. Catalyst prepared by $\mathrm{H}_{2}$ reduction of ATTM at $15^{\circ} \mathrm{C} / \mathrm{min}$ to $550^{\circ} \mathrm{C}$. 


\begin{tabular}{||c|c|c||}
\hline Pulse No. & $\begin{array}{c}\text { Reductive sulfiding } \\
\left(\mathrm{H}_{2} \mathrm{~S} \text { peak counts }\right)\end{array}$ & $\begin{array}{c}\mathrm{H}_{2} \text { reduction } \\
\left(\mathrm{H}_{2} \mathrm{~S} \text { peak counts }\right)\end{array}$ \\
\hline 1 & 108940 & 0 \\
3 & 319726 & 0 \\
4 & 274978 & 7698 \\
5 & 319726 & 19681 \\
6 & 307109 & 73334 \\
7 & 311065 & 66670 \\
8 & 314257 & 119368 \\
9 & 331790 & 158364 \\
\hline
\end{tabular}

Table 4.9: Effect of Pretreatment on $\mathrm{H}_{2} \mathrm{~S}$ Concentration

$\mathrm{H}_{2} \mathrm{~S}$ concentration increased slower than $\mathrm{H}_{2}$ reduction case. This is in agreement with the observation of Chang and Weller [4] for thiophene hydrogenolysis on $\mathrm{CoMo} / \mathrm{Al}_{2} \mathrm{O}_{3}$ catalysts by a pulse method.

It has been reported that the thiophene hydrogenolysis is inhibited by the produced $\mathrm{H}_{2} \mathrm{~S}$ due to either blocking of the active sites of the catalyst [16] or competing adsorption sites with thiophene [57], which leads to a reduction of available reaction sites for thiophene. The peak area of $\mathrm{H}_{2} \mathrm{~S}$ and conversion for 3 pulses are shown in Table 4.10. The corresponding integration curves are shown in Figure 4.12. It can be observed that when $\mathrm{H}_{2} \mathrm{~S}$ peak area increases, the thiophene conversion decreases. Therefore, the increase of $\mathrm{H}_{2} \mathrm{~S}$ concentration in reaction products appears to be the main reason for the decrease in thiophene conversion.

A typical GC signal integration curve for continuous method is shown in Figure 4.13. For both continuous and pulse methods, $\mathrm{H}_{2} \mathrm{~S}, \mathrm{C}_{1}$ components and unconverted thiophene had a clear separation. 


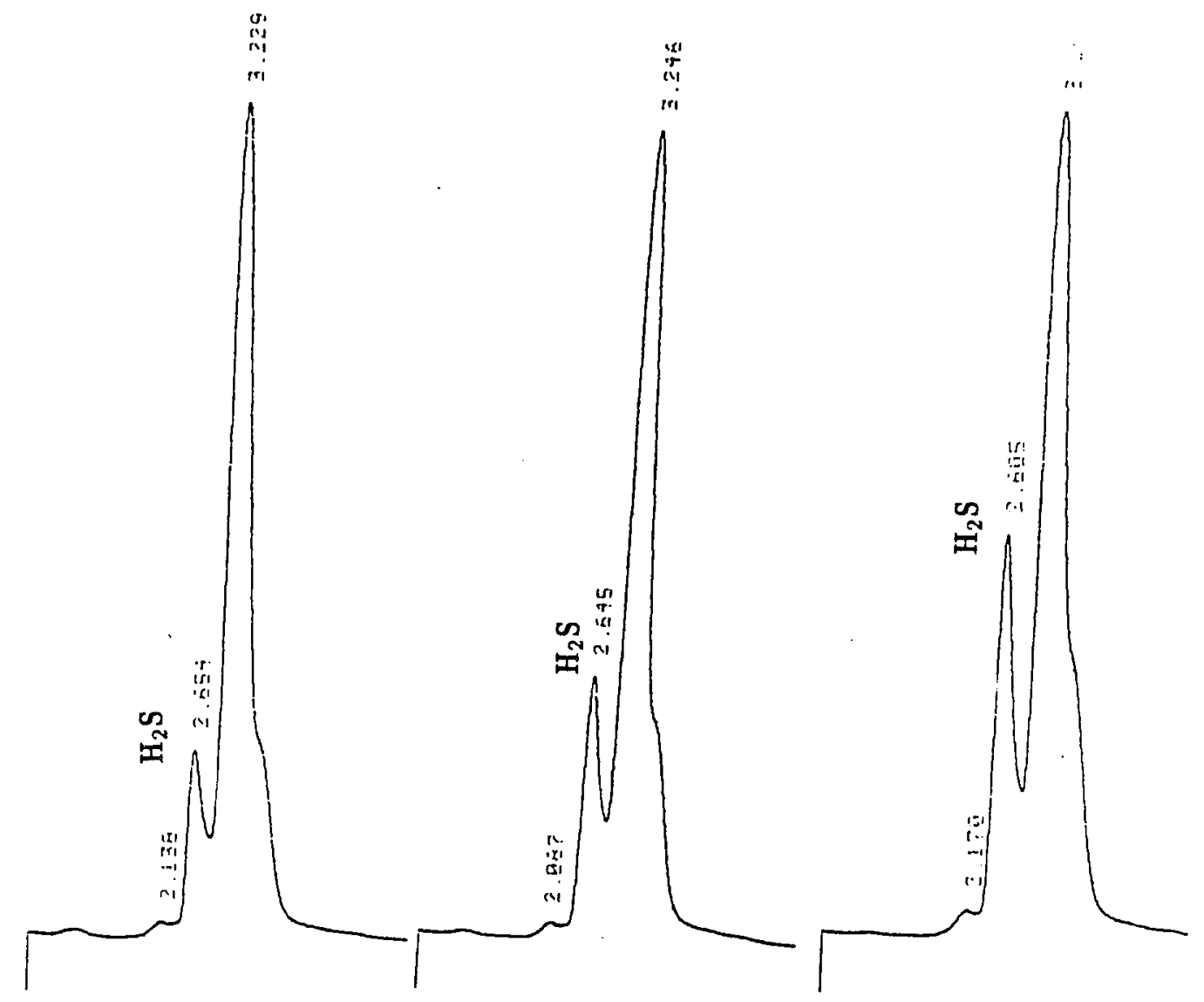

Figure 4.12: $\mathrm{H}_{2} \mathrm{~S}$ Concentration in thiophene HDS products. Catalyst Weight $=0.2 \mathrm{~g}$. Catalyst prepared by $\mathrm{H}_{2}$ reduction of ATTM 


\begin{tabular}{||c|c|c||}
\hline Pulse No. & $\begin{array}{c}\mathrm{H}_{2} \text { S Peak Area } \\
\text { (counts) }\end{array}$ & $\begin{array}{c}\text { Thiophene Conversion } \\
(\%)\end{array}$ \\
\hline 1 & 113498 & 88.4 \\
3 & 178196 & 87.3 \\
\hline
\end{tabular}

Table 4.10: Effect of $\mathrm{H}_{2} \mathrm{~S}$ Concentration on Thiophene Conversion

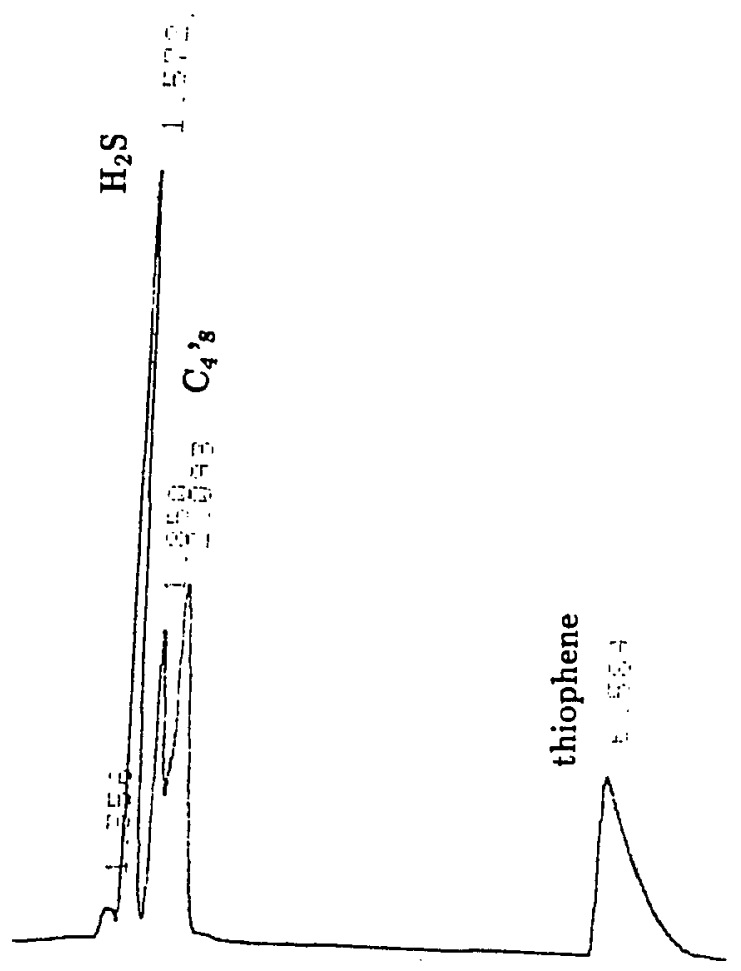

Figure 4.13: The separation of reaction products for thiophene hydrogenolysis. Continuous method. Catalyst Weight $=0.2 \mathrm{~g}$. Catalyst prepared by $\mathrm{H}_{2}$ reduction of ATTM at $15^{\circ} \mathrm{C} / \mathrm{min}$ to $550^{\circ} \mathrm{C}$. 
From the above discussion, it can be seen that although the absolute value of average conversion for pulse and continuous methods are not the same, the average conversion in both methods exhibit similar behavior with change in pretreatment. This means the variation of activity caused by different pretreatments and preparation techniques can be evaluated by both methods. Since the catalysts in the pulse method are at their initial state, they show higher average conversion compared to the catalyst prepared by the same procedure but subjected to continuous flow conditions. However, continuous methods are more representative of what might happen in an actual reactor since the reactor is at a steady state.

\subsubsection{Propylene Hydrogenation}

The determination of the nature of the hydrogenation reaction on molybdenum sulfide catalyst is a subject of considerable interest. In the present study, propylene hydrogenation, according to the following reaction, was selected as a model reaction due to its good conversion at low temperatures.

$$
\mathrm{C}_{3} \mathrm{H}_{6}+\mathrm{H}_{2} \longrightarrow \mathrm{C}_{3} \mathrm{H}_{8}
$$

Propylene conversion was measured by a continuous method. After TPR to $550^{\circ} \mathrm{C}$, the catalyst was cooled to reaction temperature, and then its activity was measured by flowing propylene $/ \mathrm{H}_{2}$ mixtures through the catalyst bed. The propylene concentration in the feed and product were monitored by gas chromatography. The propylene conversion over a certain time period was measured for various pretreatments and temperature conditions.

\section{Effect of Reaction Temperature}

Hydrogenation of olefins is very easily accomplished at low temperatures. But at low reaction temperature, a deactivating effect was observed in olefin hydrogenation, caused by preferential adsorption of unsaturated hydrocarbon [57]. The effect of temperature on propylene hydrogenation was studied at reaction temperatures of 50,100 and $150^{\circ} \mathrm{C}$. A pulse method was used to test the temperature effect on the initial propylene conversion. A 
pulse of $1 \mathrm{~mL}$ propylene was injected into a hydrogen stream at a flow rate of $35 \mathrm{~mL} / \mathrm{min}$. The peak area of the reaction product, propane, vs. reaction temperature is shown in Figure 4.14. It can be seen for $\mathrm{ATTM} / \mathrm{Al}_{2} \mathrm{O}_{3}$ pretreated by hydrogen reduction, a temperature of $100^{\circ} \mathrm{C}$ gives the best initial conversion for propylene hydrogenation. A continuous method was used to monitor propylene conversion as a function of time. The results are shown in Figures 4.15 and 4.16. The initial conversion at $100^{\circ} \mathrm{C}$ is higher than at $50^{\circ} \mathrm{C}$, and the initial conversion at $150^{\circ} \mathrm{C}$ is slightly lower than at $50^{\circ} \mathrm{C}$, which is in agreement with the observation using the pulse method. Since the deactivation at $100^{\circ} \mathrm{C}$ and $150^{\circ} \mathrm{C}$ is higher than that at $50^{\circ} \mathrm{C}$, it was decided that all the other experiments would be conducted at $50^{\circ} \mathrm{C}$.

\section{Effect of Thermal Decomposition Heating Rate}

The heating rate during $\mathrm{ATTM} / \mathrm{Al}_{2} \mathrm{O}_{3}$ thermal decomposition affects product morphology. Previous data in Table 4.4 shows that the LTOC value and the thiophene HDS activity for $10^{\circ} \mathrm{C} / \mathrm{min}$-decomposed sample are higher than that for the flash-decomposed sample. Based on this observation and the assumption that oxygen is a selective chemisorbate for edge sites [47], it was concluded in section 4.3 that the crystallites in the catalysts may mainly be edge planes for temperature-programmed decomposition, and basal plane for flash decomposed sample.

The results of propylene hydrogenation activity measurements for the above two pretreatments are shown in Figure 4.17. The propylene conversions were measured by a continuous method for 3 hours. The conversions for both pretreatments are very close, which implies that basal and edge planes provide almost the same hydrogenation activity after temperature-programmed reduction in hydrogen to $550^{\circ} \mathrm{C}$. This is in agreement with Kalthod [16] for unsupported molybdenum sulfide catalyst prepared by the same pretreatments. For unsupported ATTM, the catalyst prepared from flash-decomposed ATTM shows a higher initial surface area compared to $10^{\circ} \mathrm{C} / \mathrm{min}$-decomposed ATTM, but the specific hydrogenation activities $\left(k_{s}\right)$ of the two catalysts at $150^{\circ} \mathrm{C}$ are $1.30 \times 10^{10} \mathrm{~mol} / \mathrm{cm}^{2} \mathrm{sec}$ for 


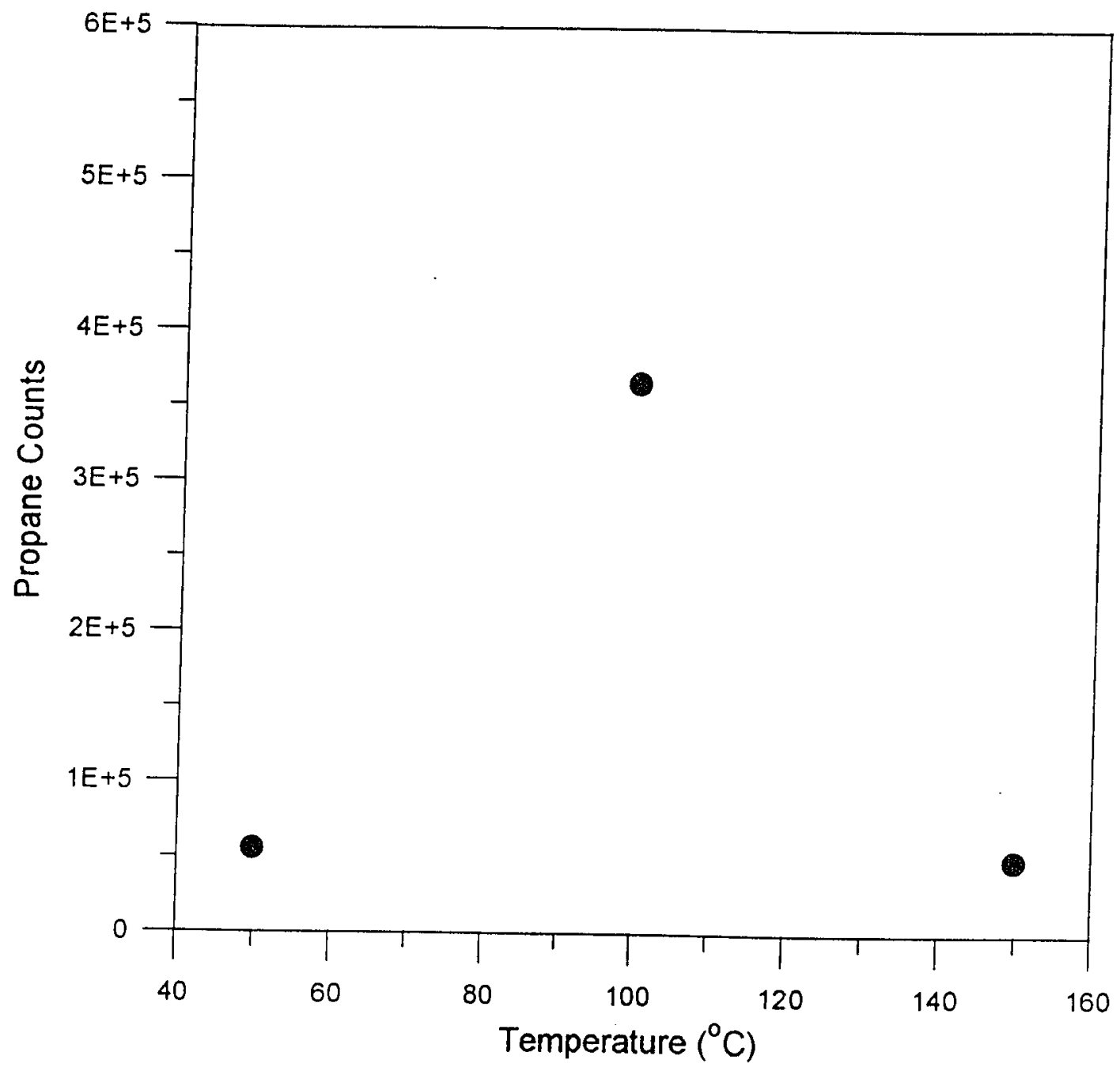

Figure 4.14: Propylene HYD activity measured by a pulse method 49 


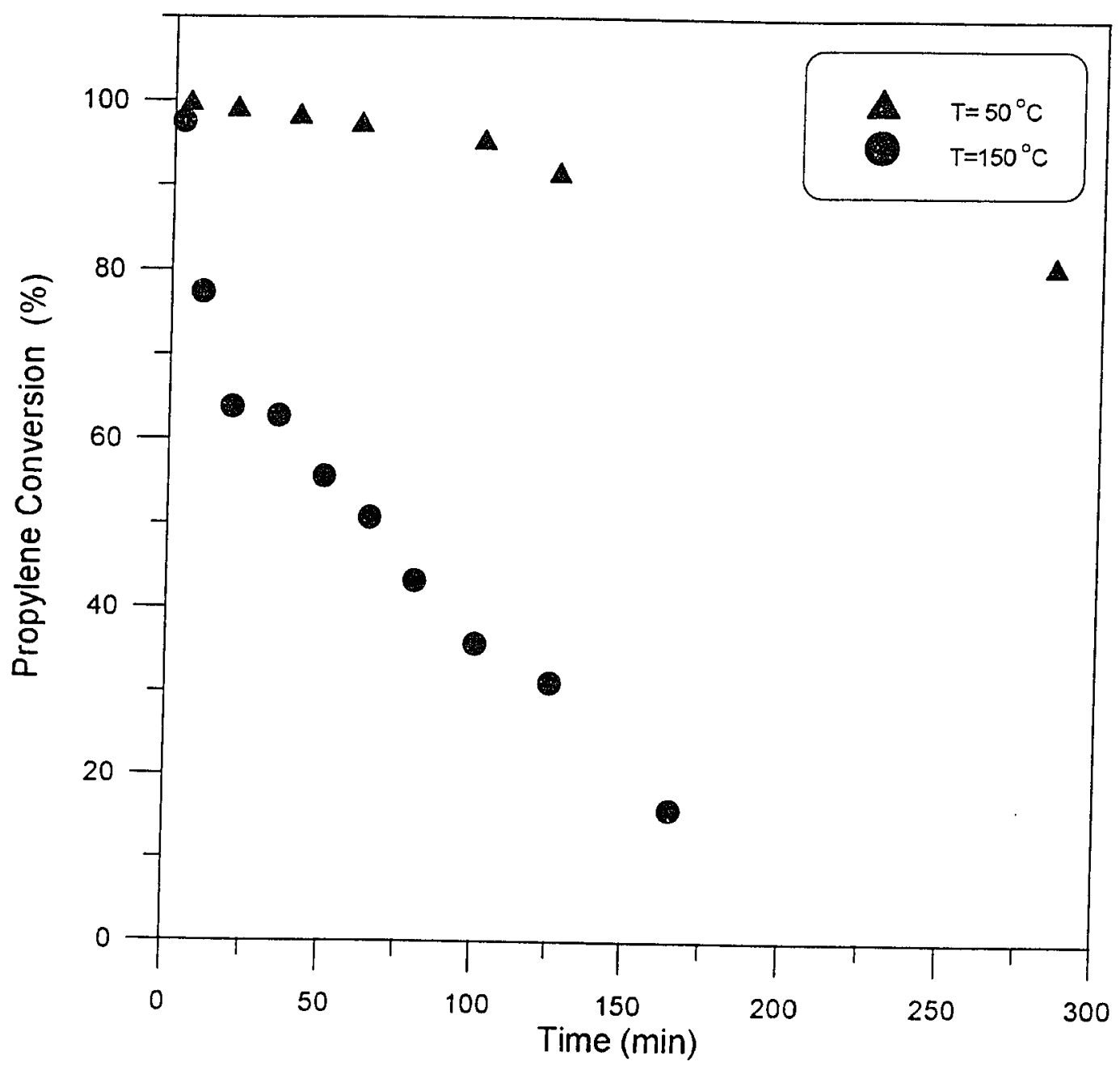

Figure 4.15: Effect of reaction temperat ure on HYD activity. Catalyst Weight $=0.2 \mathrm{~g}$. $\mathrm{H}_{2}: \mathrm{C}_{3} \mathrm{H}_{6}=1.5: 1$. Catalysts prepared by the reduction of ATTM in $\mathrm{H}_{2}$. 


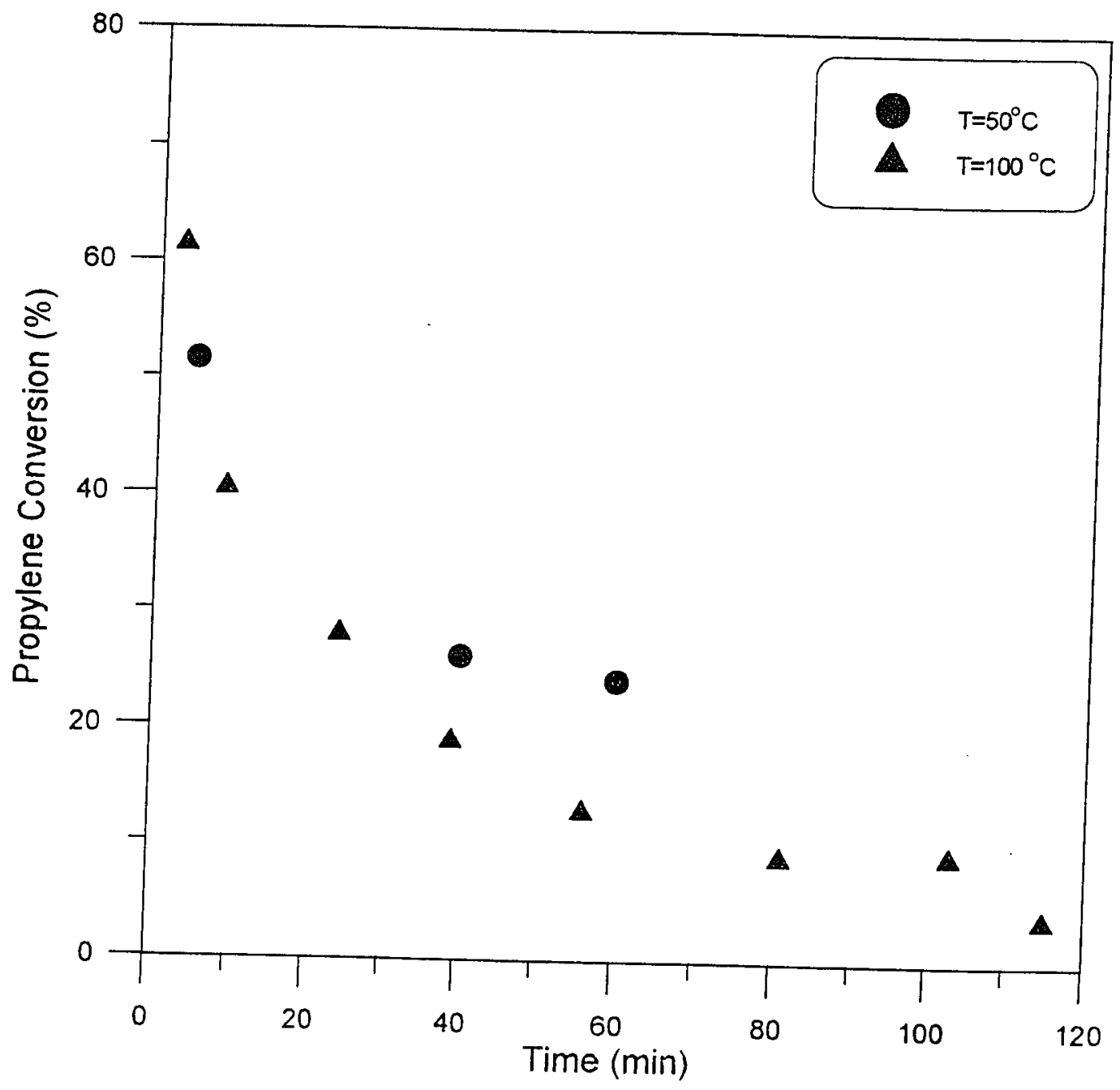

Figure 4.16: Effect of reaction temperature on HYD activity. Catalyst Weight $=0.05 \mathrm{~g}$. $\mathrm{H}_{2}: \mathrm{C}_{3} \mathrm{H}_{6 j}=5: 1$. Catalysts prepared by the reduction of ATTM in $\mathrm{H}_{2}$. 
flash-decomposed sample and $1.40 \times 10^{10} \mathrm{~mol} / \mathrm{cm}^{2} \mathrm{sec}$ for $10^{\circ} \mathrm{C} / \mathrm{min}$-decomposed sample, which are within error of $7.6 \%$.

\section{Comparison of Different Catalysts}

The effect of catalyst preparation technique on propylene conversion is shown in Figure 4.18. For reactant concentration at $\mathrm{H}_{2}: \mathrm{C}_{3} \mathrm{H}_{6}=1.5: 1$, the $\mathrm{MoS}_{y} / \mathrm{Al}_{2} \mathrm{O}_{3}$ catalyst prepared by hydrogen reduction of ATTM alone showed the highest propylene HYD conversion. The Harshaw $0402 \mathrm{~T}$ catalyst prepared by reductive sulfiding had an intermediate conversion and the conventional oxide catalyst with the same Mo loading as the $\mathrm{MoS}_{y} / \mathrm{Al}_{2} \mathrm{O}_{3}$ catalyst, and prepared by reductive sulfiding was the least active.

\section{Effect of Sample Size}

The effect of sample size on propylene conversion and deactivation is shown in Figure 4.19. For the catalyst prepared by thermal decomposition at $10^{\circ} \mathrm{C} / \mathrm{min}$ followed by $\mathrm{TPR}$, a sample size of $0.2 \mathrm{~g}$ gave a higher conversion and lower deactivation for the first 3 hours compared to the sample size of $0.08 \mathrm{~g}$. The higher conversion for the larger sample size is expected since it had more available sites for the reaction. Since the deactivation is mainly caused by preferential adsorption of propylene, it is possible that the lower deactivation for larger sample size, which has a higher capacity for propylene adsorption, is caused by lower propylene saturation, since the reactant flow rates were the same.

\section{$\underline{\text { Deactivation and Regeneration }}$}

From the figures of propylene conversion vs. time, it can be seen that deactivation is prevalent in all the catalysts under the reaction conditions specified above. The deactivation of catalyst during olefin hydrogenation is usually caused by preferential adsorption of unsaturated hydrocarbon [57]. In our study, when the deactivated catalyst was heated again in hydrogen, a big desorption peak appeared at about $100-150^{\circ} \mathrm{C}$ as shown in Figure 4.20 . 


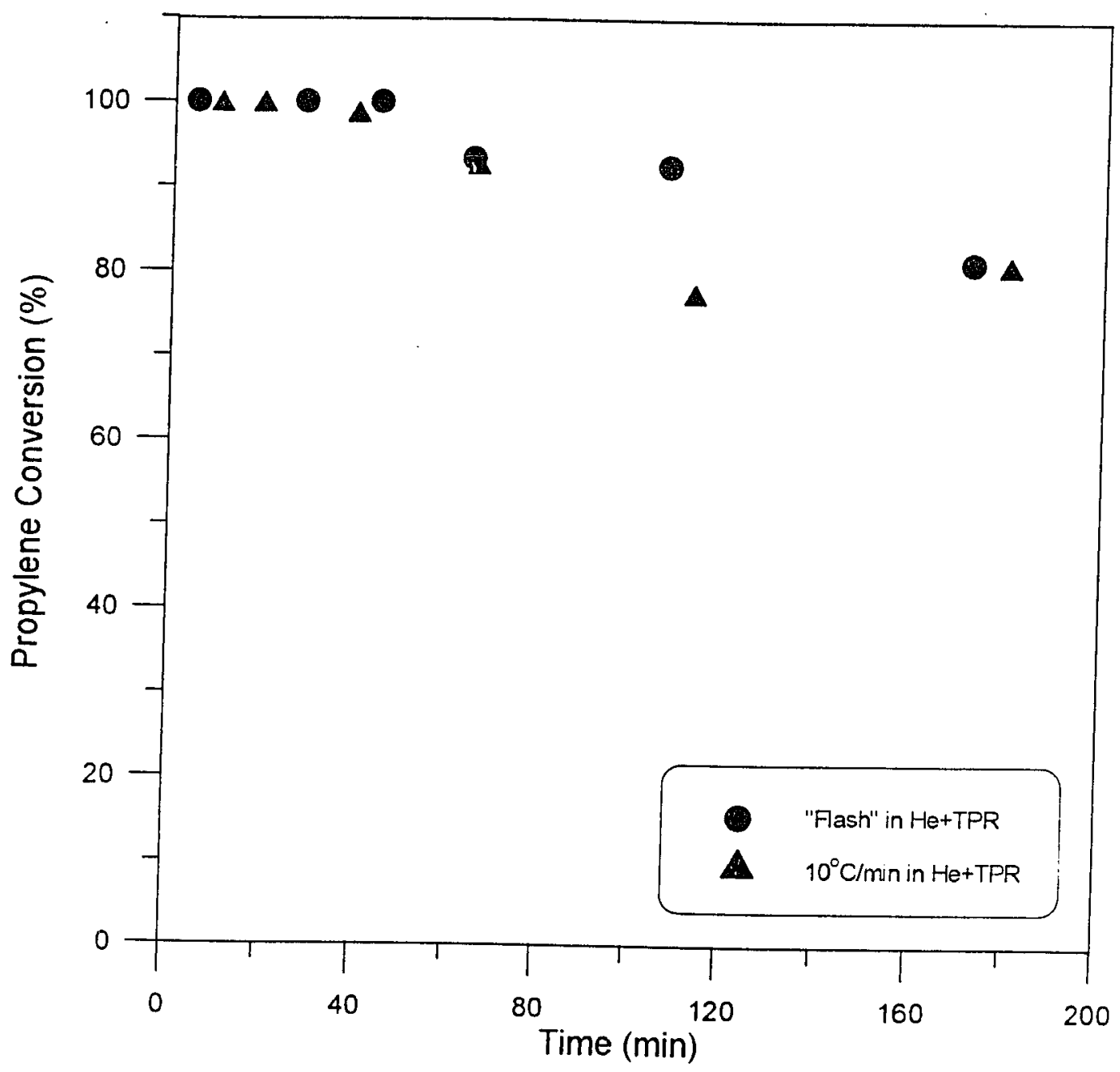

Figure 4.17: Effect of thermal decomposition heating rate on HYD activity. Catalyst Weight $=0.2 \mathrm{~g} . \mathrm{T}=50^{\circ} \mathrm{C} . \mathrm{H}_{2}: \mathrm{C}_{3} \mathrm{H}_{6}=1.5: 1$ Catalysts prepared by flash and $10^{\circ} \mathrm{C} / \mathrm{min}$ thermal decomposition of ATTM in He followed by TPR. 


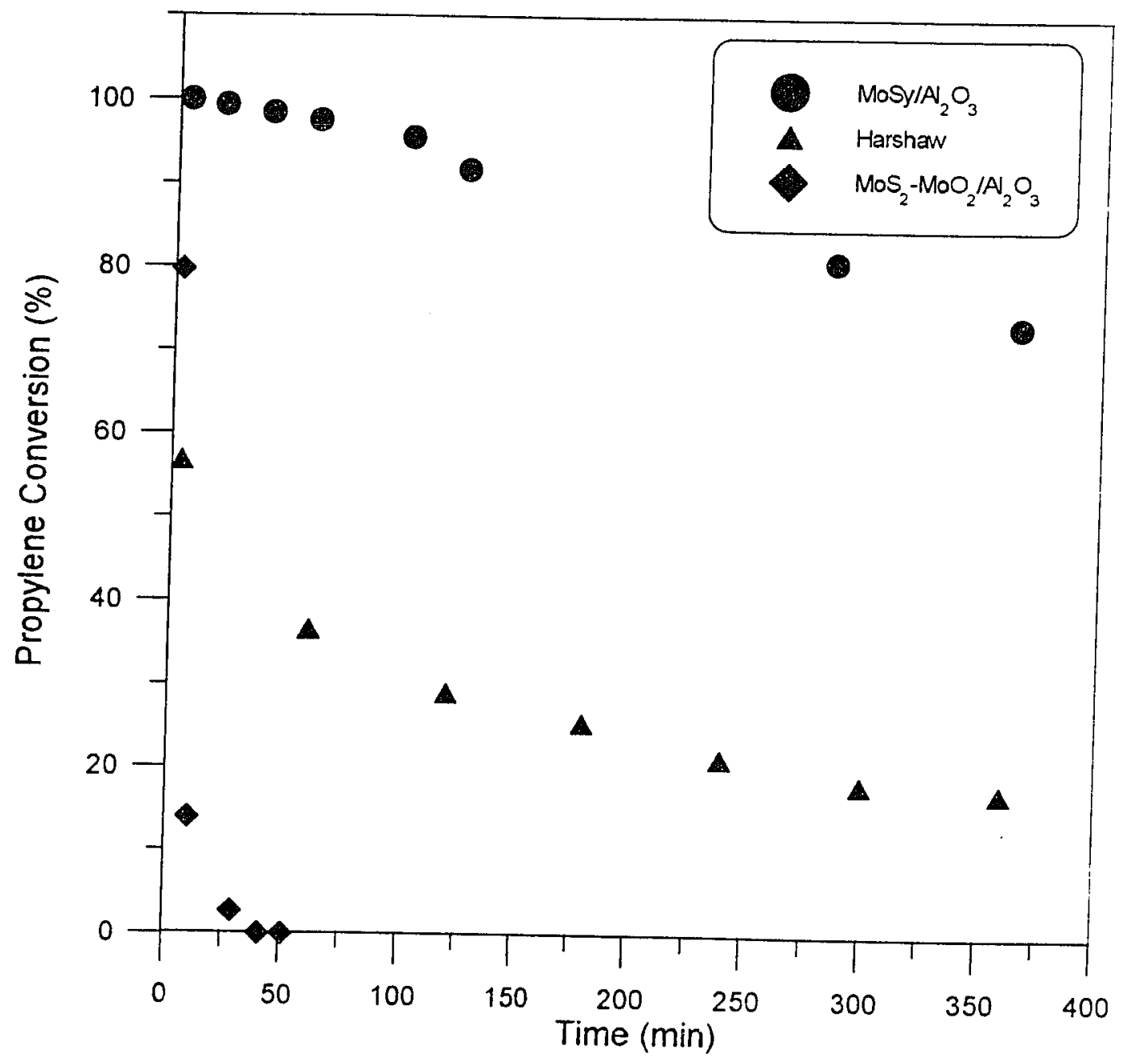

Figure 4.18: Effect of catalyst preparation on HYD activity. Catalyst Weight $=0.2 \mathrm{~g}$. T $=50^{\circ} \mathrm{C} . \mathrm{H}_{2}: \mathrm{C}_{3} \mathrm{H}_{6}=1.5: 1$. Catalysts prepared by $\mathrm{H}_{2}$ reduction of ATTM, and reductive sulfiding of $\mathrm{MoO}_{3}$ and Harshaw $0402 \mathrm{~T}$ followed by TPR. 


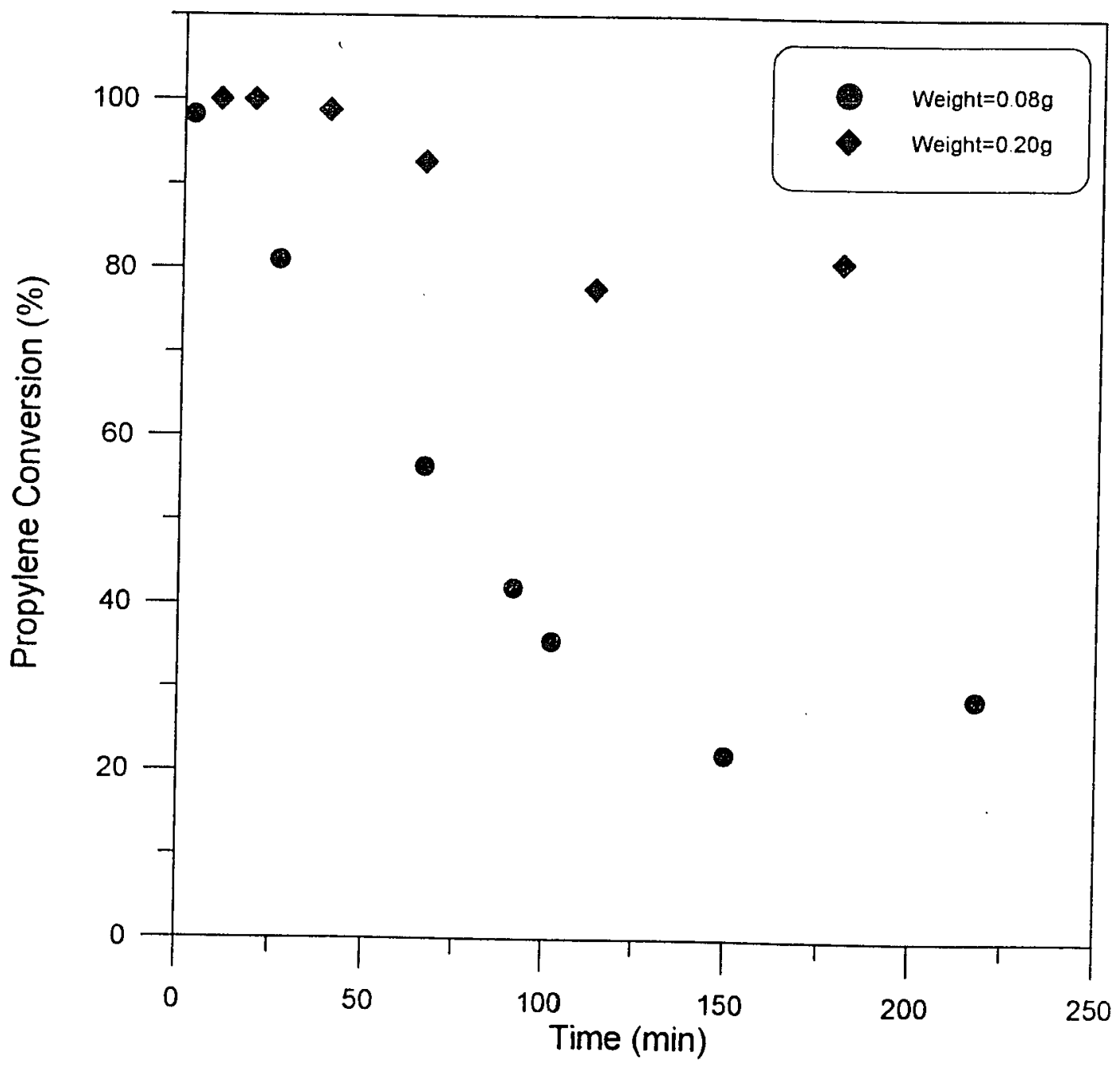

Figure 4.19: Effect of sample size on HYD activity. $\mathrm{T}=50^{\circ} \mathrm{C} . \mathrm{H}_{2}: \mathrm{C}_{3} \mathrm{H}_{\mathrm{t}}=1.5: 1$. Catalyst prepared by $10^{\circ} \mathrm{C} / \mathrm{min}$ thermal decomposition of ATTM in He followed by TPR 
Propylene conversion vs. time at different initial propylene concentration is shown in Figure 4.21. It was observed that when the ratio of hydrogen to propylene in the initial reactant increased from $1.5: 1$ to $3: 1$, the deactivation decreased. It suggests that the deactivation is more rapid when the partial pressure of propylene in the initial reactant is higher.

Regeneration of catalyst by conducting a temperature-programmed reduction in hydrogen at $15^{\circ} \mathrm{C} / \mathrm{min}$ to $550^{\circ} \mathrm{C}$ was studied. The original catalytic activity can be regenerated after heating. Furthermore, the regenerated catalysts exhibited a much lower deactivation rate compared to fresh catalyst probably due to the recrystalization of the catalyst [57]. The propylene conversion vs. time for the fresh catalyst and the same catalyst after first and second regeneration is shown in Figure 4.22. Since deactivation is mostly caused by adsorption of propylene, heating in hydrogen can remove the propylene from active sites and therefore recover catalytic activity. In Berthelot and Collepardi's work [57], ethylene hydrogenation was conducted on $\mathrm{MoS}_{2}-\mathrm{WS}_{2} / \mathrm{Al}_{2} \mathrm{O}_{3}-\mathrm{SiO}_{2}$ catalysts. They studied the deactivation effect of adsorbed ethylene by saturating the catalysts with ethylene before the hydrogenation experiment, and proved the deactivation takes place only after the saturation of active catalyst surface. In their study, the original catalytic activity can be regenerated on heating the catalyst to $400^{\circ} \mathrm{C}$ even when the catalyst was exposed in air for 10 days. But for our catalyst, the catalyst can not be regenerated if it is exposed in air.

\subsection{Temperature-Programmed Desorption}

Generally, the coordinatively unsaturated sites and associated anion vacancies are considered to be the active sites for oxygen chemisorption and HDS, HYD reactions. An approach to study the anion vacancies is by measuring $\mathrm{H}_{2} \mathrm{~S}$ evolution from the surface during temperature-programmed desorption (TPD) of $\mathrm{H}_{2} \mathrm{~S}$. Molybdenum sulfide is prepared by thermal decomposition of ATTM/ $\mathrm{Al}_{2} \mathrm{O}_{3}$ in $\mathrm{He}$, after which, the catalyst is cooled to room temperature and heated in $\mathrm{H}_{2}$ at $15^{\circ} \mathrm{C} / \mathrm{min}$ to $550^{\circ} \mathrm{C}$ until further sulfur loss is negligible. If a $15 \% \mathrm{II}_{2} \mathrm{~S} / \mathrm{H}_{2}$ mixture is passed through the pretreated catalyst at room temperature, 


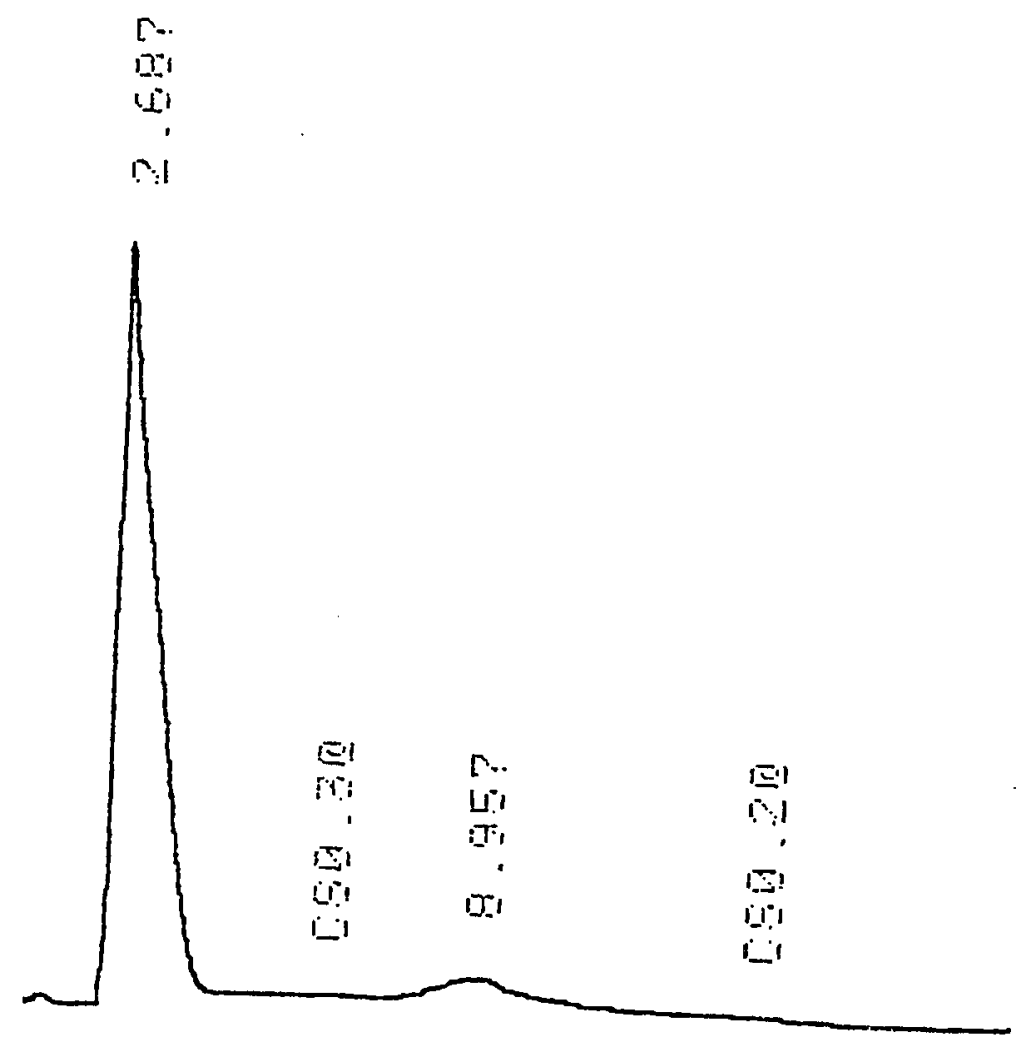

Figure 4.20: $\mathrm{C}_{3} \mathrm{H}_{6}$ effluent during temperature-programmed regeneration of catalyst 


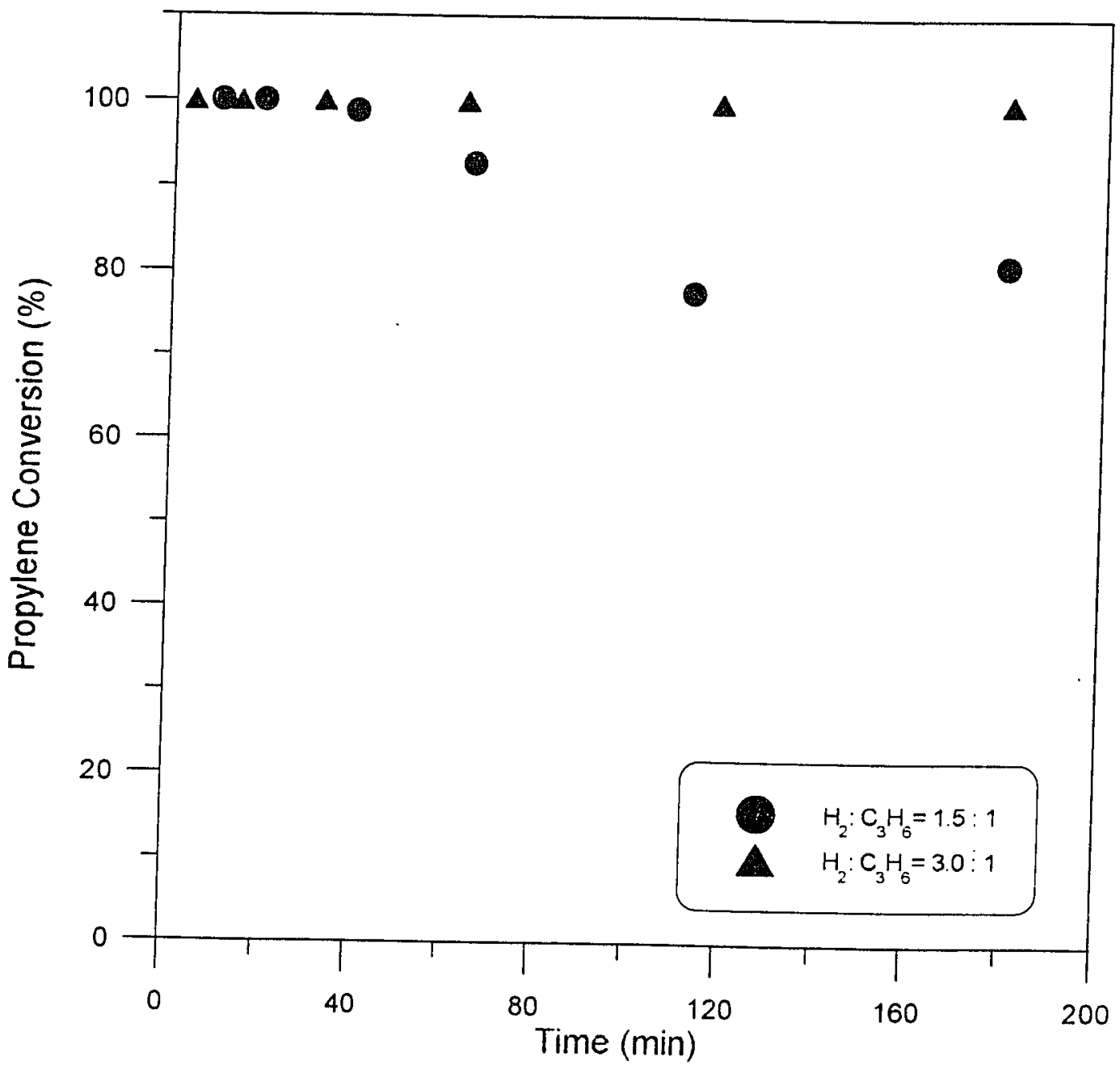

Figure 4.21: Effect of reactant concentration on HYD activity: Catalyst Weight $=0.2 \mathrm{~g}$. $\mathrm{T}$ $=50^{\circ} \mathrm{C}$. Catalysts prepared by $10^{\circ} \mathrm{C} / \mathrm{min}$ thermal decomposition of ATTM in He followed by TPR.

58 


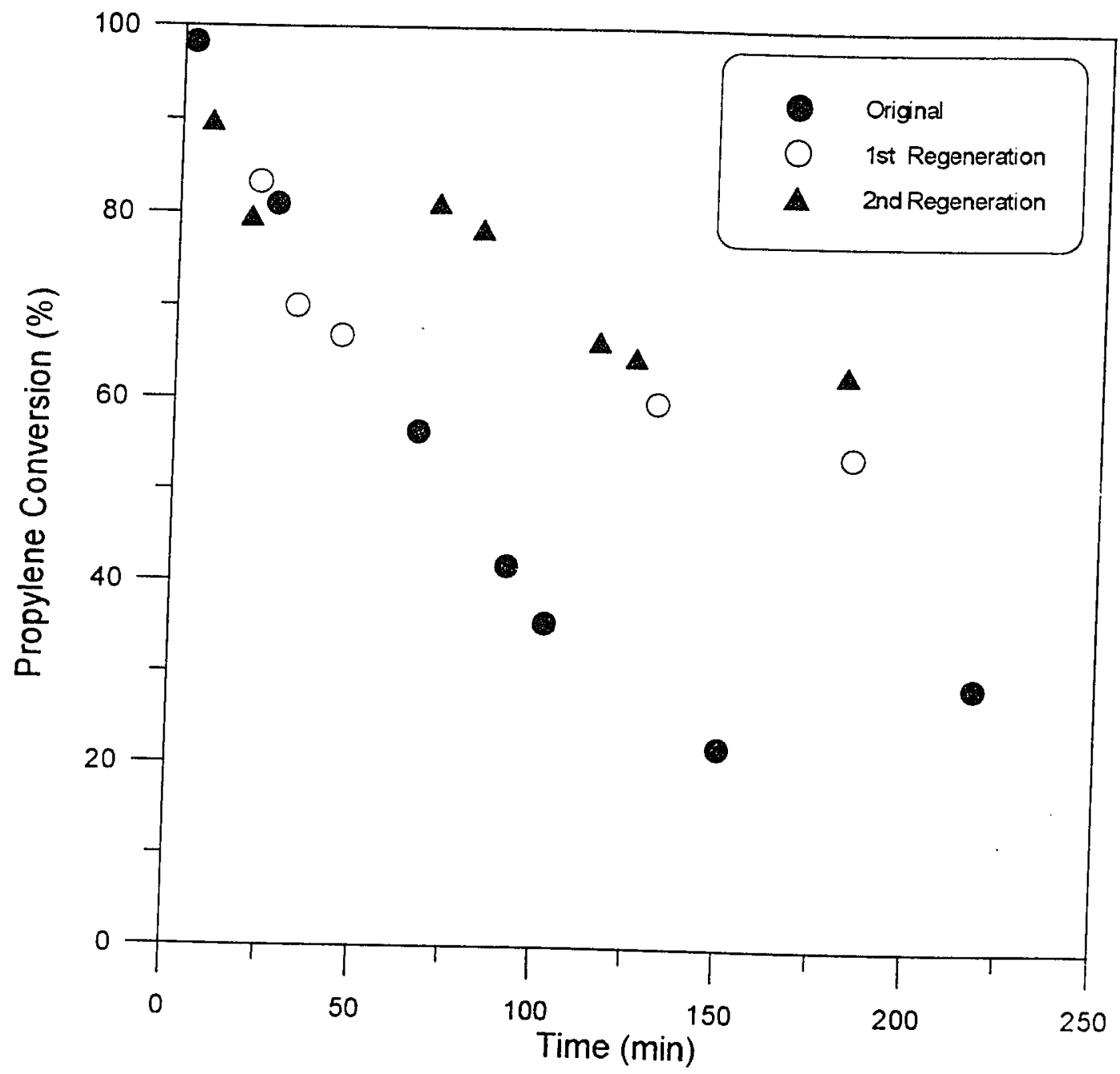

Figure 4.22: Catalyst regeneration by heating in $\mathrm{H}_{2}$ at $15^{\circ} \mathrm{C} / \mathrm{min}$ to $550^{\circ} \mathrm{C}$. Catalyst Weight $=0.08 \mathrm{~g} . \mathrm{T}=50^{\circ} \mathrm{C} . \mathrm{H}_{2}: \mathrm{C}_{3} \mathrm{H}_{6}=1.5: 1$. Catalysts prepared by $10^{\circ} \mathrm{C} / \mathrm{min}$ thermal decomposition of ATTM in He followed by TPR. 


\begin{tabular}{||c|l|c|c|c||}
\hline catalyst & Pretreatment & $\begin{array}{c}\mathrm{TPD} \\
\mathrm{H}_{2} \mathrm{~S}(\mathrm{~mL} / \mathrm{g})\end{array}$ & $\begin{array}{c}\text { LTOC } \\
(\mathrm{mL} / \mathrm{g})\end{array}$ & $\begin{array}{c}\text { HDS Activity } \\
\text { Conversion(\%) }\end{array}$ \\
\hline $\mathrm{ATTM} / \mathrm{Al}_{2} \mathrm{O}_{3}$ & Flash+TPR & 19.0 & 1.31 & 68.0 \\
$\mathrm{ATTM} / \mathrm{Al}_{2} \mathrm{O}_{3}$ & $10^{\circ} \mathrm{C} / \min +\mathrm{TPR}\left(550^{\circ} \mathrm{C}\right)$ & 15.0 & 1.42 & 70.4 \\
$\mathrm{ATTM} / \mathrm{Al}_{2} \mathrm{O}_{3}$ & $\mathrm{H}_{2}$ reduction & 19.0 & 0.79 & 71.3 \\
$\mathrm{ATTM} / \mathrm{Al}_{2} \mathrm{O}_{3}$ & $10^{\circ} \mathrm{C} / \min +\mathrm{TPR}\left(420^{\circ} \mathrm{C}\right)$ & 10.1 & 0.66 & 56.0 \\
$\mathrm{MoO}_{3} / \mathrm{Al}_{2} \mathrm{O}_{3}$ & $\mathrm{H}_{2} \mathrm{~S} / \mathrm{H}_{2}+\mathrm{TPR}$ & 10.7 & 0.55 & 55.0 \\
$\mathrm{Harshaw} 0402 \mathrm{~T}$ & $\mathrm{H}_{2} \mathrm{~S} / \mathrm{H}_{2}+\mathrm{TPR}$ & 7.26 & 0.19 & 66.5 \\
\hline
\end{tabular}

Table 4.11: Temperature-Programmed Desorption of $\mathrm{H}_{2} \mathrm{~S}$

the $\mathrm{H}_{2} \mathrm{~S}$ chemisorbs on all accessible vacancies. After purging the catalyst with pure He at room temperature to remove non-chemisorbed $\mathrm{H}_{2} \mathrm{~S}$, the chemisorbed $\mathrm{H}_{2} \mathrm{~S}$ can be desorbed by heating in hydrogen at $15^{\circ} \mathrm{C} / \mathrm{min}$ to $550^{\circ} \mathrm{C}$ (TPD). Since the catalyst has been heated earlier in hydrogen to $550^{\circ} \mathrm{C}$, no further loss of sulfur from the bulk is expected. Thus the $\mathrm{H}_{2} \mathrm{~S}$ evolution during TPD is a measure of the surface vacancies. The results of TPD experiments are listed in Table 4.11. LTOC data given here were measured after TPR instead of TPD.

The TPD profiles for different catalysts and different pretreatments are shown in Figure 4.23. Three peaks at about $160^{\circ} \mathrm{C}, 260^{\circ} \mathrm{C}$, and $550^{\circ} \mathrm{C}$ are presented in all the profiles.

After thermal decomposition of $\mathrm{ATTM} / \mathrm{Al}_{2} \mathrm{O}_{3}$ in $\mathrm{He}$ at $10^{\circ} \mathrm{C} / \mathrm{min}$ to $450^{\circ} \mathrm{C}$, the catalyst was subjected to TPR to $420^{\circ} \mathrm{C}$ (or $550^{\circ} \mathrm{C}$ ) followed by TPD to the same temperature. $420^{\circ} \mathrm{C}$ is the temperature just beyond the first TPR peak. The $\mathrm{H}_{2} \mathrm{~S}$ TPD peaks for different reduction temperatures are shown in Figure 4.24. It can be seen that when the sulfur was further removed by conducting TPR to $550^{\prime \prime} \mathrm{C}$, there was a big increase for the peak area under TPD curve (b), compared to the peak area under curve (a). Since the peak area corresponds to the removal of $\mathrm{H}_{2} \mathrm{~S}$ from the surface, the catalyst in which TPR was conducted 


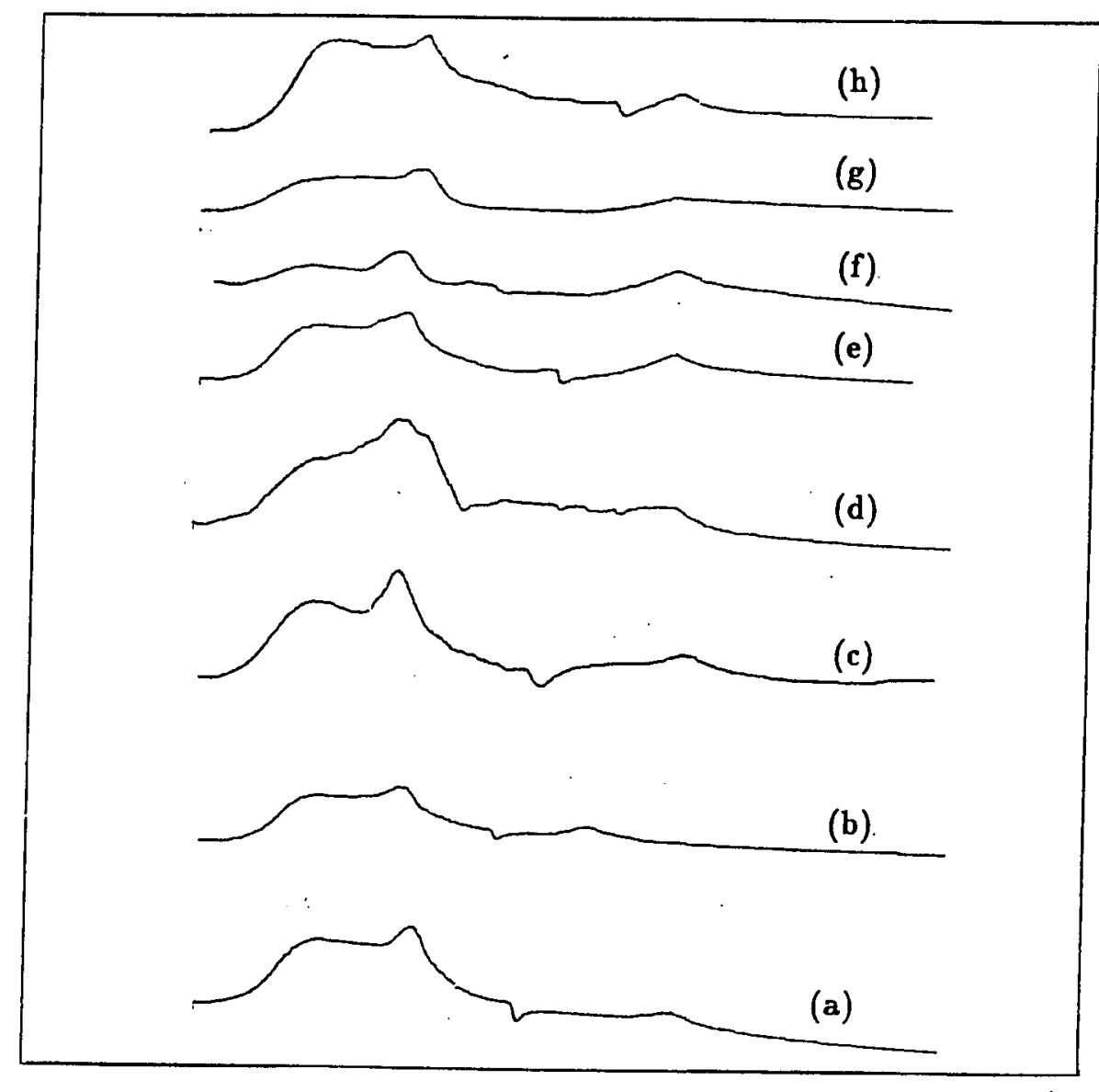

Temperature $\left({ }^{\circ} \mathrm{C}\right)$

Figure 4.23: TPD profiles for $\mathrm{Mo} / \mathrm{Al}_{2} \mathrm{O}_{3}$ and $\mathrm{CoMo} / \mathrm{Al}_{2} \mathrm{O}_{3}$ catalysts (a) ATTM $/ \mathrm{Al}_{2} \mathrm{O}_{3}$ : $10^{\circ} \mathrm{C} / \mathrm{min}+\mathrm{TPR}$ to $550^{\circ} \mathrm{C}$ (b) $\mathrm{ATTM} / \mathrm{Al}_{2} \mathrm{O}_{3}: 10^{\circ} \mathrm{C} / \mathrm{min}+\mathrm{TPR}$ to $420^{\circ} \mathrm{C}$ (c) ATTM $/ \mathrm{Al}_{2} \mathrm{O}_{3}:$ Flash + TPR to $550^{\circ} \mathrm{C}$ (d) ATTM $/ \mathrm{Al}_{2} \mathrm{O}_{3}: \mathrm{H}_{2}$ reduction (e) ATTM $/ \mathrm{Al}_{2} \mathrm{O}_{3}$ : $10^{\circ} \mathrm{C} / \mathrm{min}+$ Reductive sulfiding + TPR (f) Harshaw: Reductive sulfiding + TPR (g) Harshaw: $\mathrm{H}_{2}$ Reduction (h) $\mathrm{MoO}_{3} / \mathrm{Al}_{2} \mathrm{O}_{3}$ : Reductive sulfiding + TPR

61 
to $550^{\circ} \mathrm{C}$ has more surface anion vacancies. The LTOC value and thiophene activity were also higher after the second TPR peak which corresponds to an increase in anion vacancies at edge plane.

Comparison of the TPD profiles of the flash-decomposed and $10^{\circ} \mathrm{C} / \mathrm{min}$-decomposed samples is shown in Figure 4.25. The $\mathrm{H}_{2} \mathrm{~S}$ evolution for a flash-decomposed sample is 19.0 $\mathrm{mL} / \mathrm{g}$ which is much higher than $15.0 \mathrm{~mL} / \mathrm{g}$ for a $10^{\circ} \mathrm{C} / \mathrm{min}$-decomposed sample. This suggests that there are more surface anion vacancies being formed for flash-decomposed sample compared to $10^{\circ} \mathrm{C} / \mathrm{min}$-decomposed sample. But, since the LTOC value and HDS/HYD activity of the catalyst for flash-decomposed samples are not higher than $10^{\circ} \mathrm{C} / \mathrm{min}$ sample as discussed in section 4.3 , it is possible that the flash-decomposed samples exhibit a small proportion of edge sites, which are believed to be HDS and HYD active sites $[15,19,39,47]$, than the $10^{\circ} \mathrm{C} / \mathrm{min}$-decomposed sample, even though the total amount of its anion vacancies is larger. For unsupported ATTM following the same thermal decomposition procedure [16], the TPD $\mathrm{H}_{2} \mathrm{~S}$ evolution for flash-decomposed sample is $2.01 \mathrm{~mL} / \mathrm{g}$, which is also higher than $0.79 \mathrm{~mL} / \mathrm{g}$ for $10^{\circ} \mathrm{C} / \mathrm{min}$-decomposed sample. The propylene hydrogenation activity for the unsupported flash-decomposed sample is not higher than for the $10^{\circ} \mathrm{C} / \mathrm{min}$-decomposed sample, either.

If oxygen chemisorbed dissociatively with one atom on each anion vacancy, the ratio of $\mathrm{H}_{2} \mathrm{~S}$ evolved/LTOC should equal to 2. However this ratio is much higher than 2 for the catalysts in our study. This means a particular geometrical configuration of vacancies, such as a pair of adjacent vacancies, is necessary to adsorb oxygen. The same interpretation has been suggested by Millman and $\mathrm{Hall}$ [29] for $\mathrm{MoO}_{3} / \mathrm{Al}_{2} \mathrm{O}_{3}$ catalysts, and has been observed by Kalthod for unsupported ATTM [16].

Comparison of the TPD profile for catalysts with different preparation techniques is shown in Figure 4.26. The $\mathrm{MoS}_{y} / \mathrm{Al}_{2} \mathrm{O}_{3}$ catalyst prepared by decomposition of ATTM in hydrogen showed the highest $\mathrm{H}_{2} \mathrm{~S}$ evolution. The conventional oxide catalyst with the same Mo loading as the $\mathrm{MoS}_{y} / \mathrm{Al}_{2} \mathrm{O}_{3}$, prepared by reductive sulfiding had an intermediate $\mathrm{H}_{2} \mathrm{~S}$ evolution. The Harshaw $0402 \mathrm{~T}$ had the least amount of $\mathrm{H}_{2} \mathrm{~S}$ evolution. This suggests that 


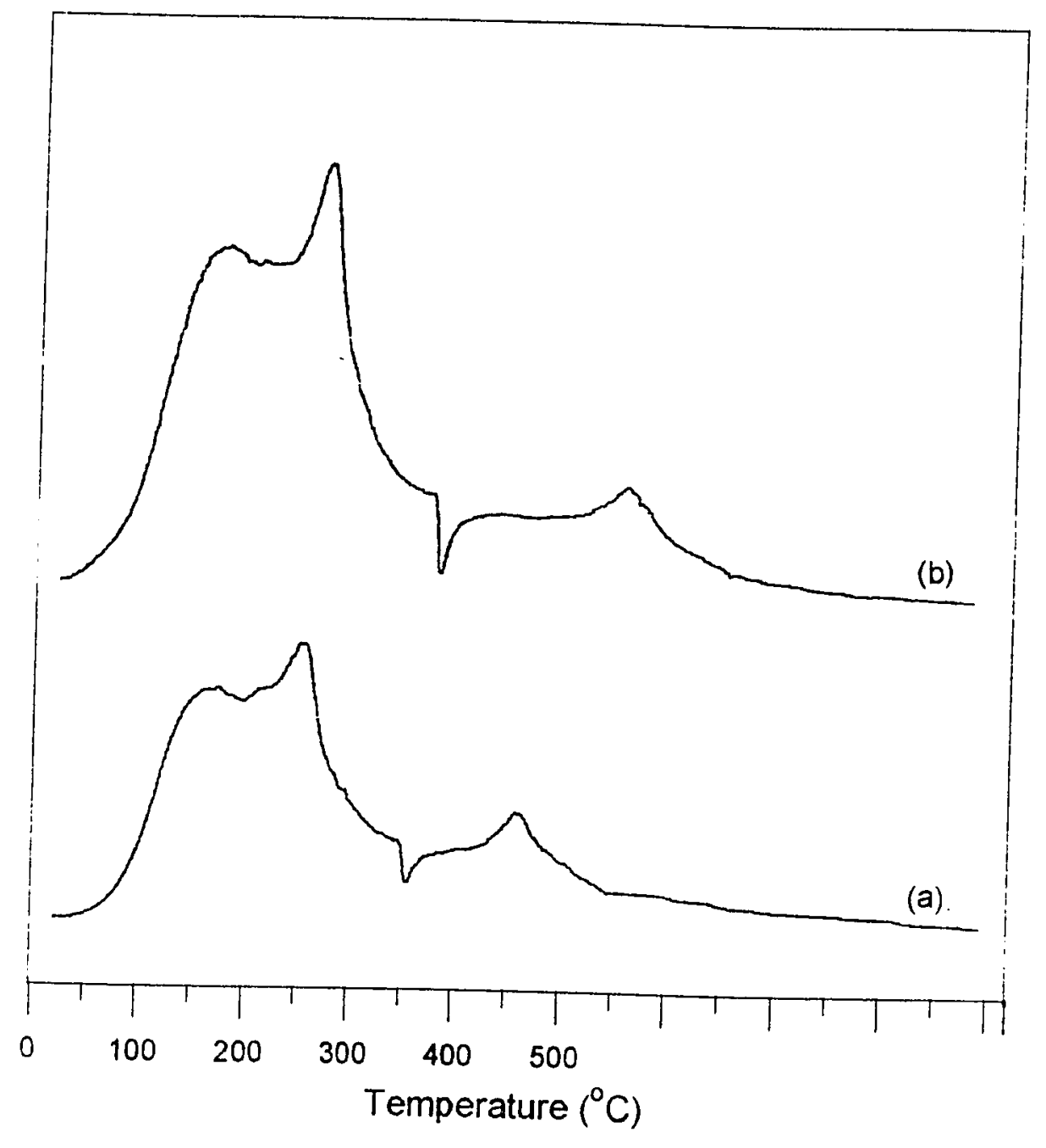

Figure 4.24: Effect of reduction temperature on TPD profiles. Catalyst Weight $=0.2 \mathrm{~g}$. Catalyst prepared by thermal decomposition of ATTM at $10^{\circ} \mathrm{C} / \mathrm{min}$ in He followed by TPR to $(\mathrm{a}) 420^{\circ} \mathrm{C}(\mathrm{b}) 550^{\circ} \mathrm{C}$ 


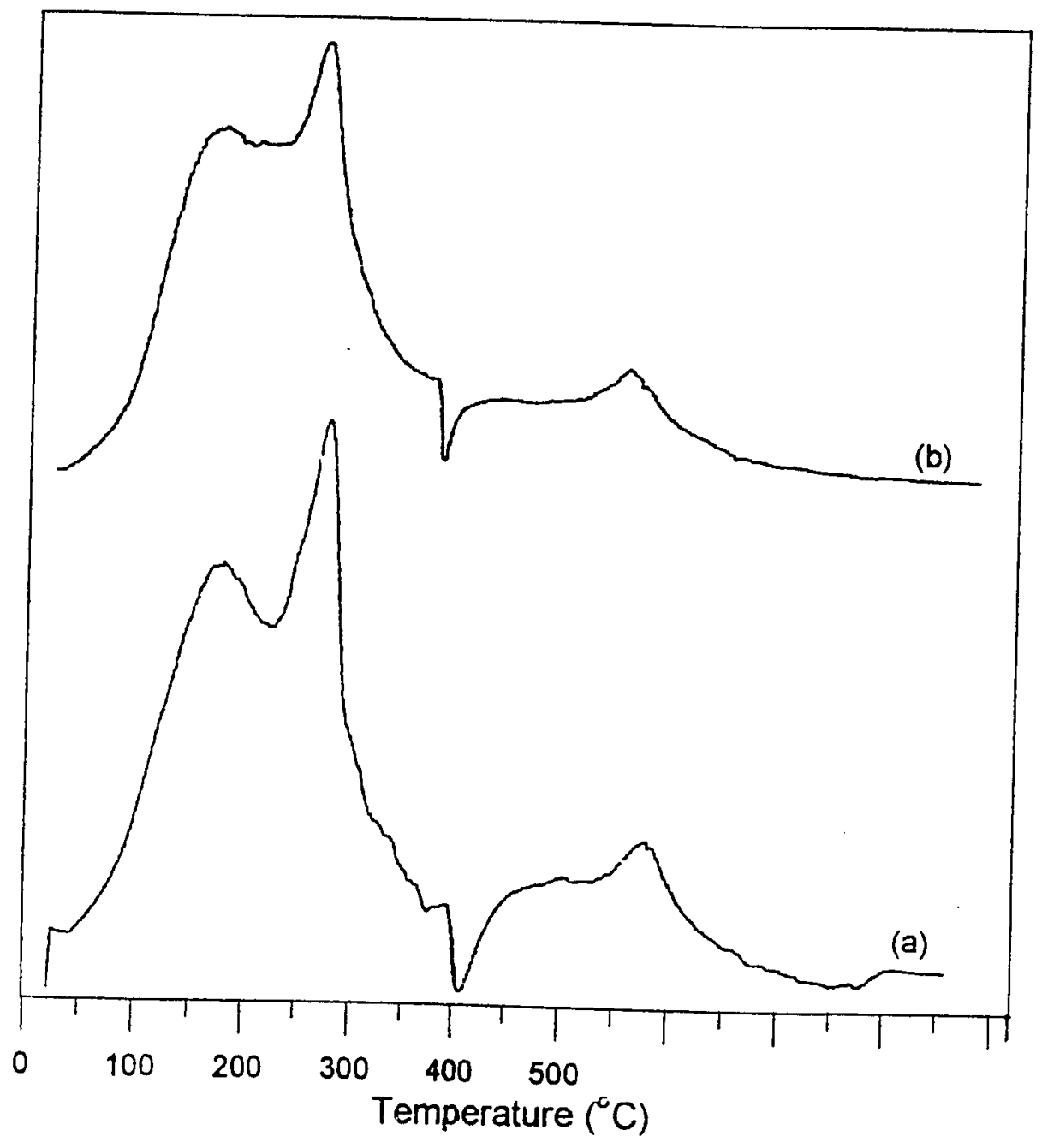

Figure 4.25: Effect of thermal decomposition heating rate on TPD profiles. Catalyst Weight $=0.2 \mathrm{~g}$. Catalyst prepared by (a) flash decomposition at $450^{\circ} \mathrm{C}(\mathrm{b}) 10^{\circ} \mathrm{C} / \mathrm{min}$ decomposition to $450^{\prime \prime} \mathrm{C}$, followed by TPR 
of the three, the catalyst prepared by hydrogen reduction has the highest amount of surface anion vacancies, possibly more edge sites, which is supported by the activity measurement for thiophene HDS and propylene HYD reactions. The conventional oxide catalyst had more anion vacancies than Harshaw 0402T according to TPD and LTOC measurements. But it had a lower activity for HDS and HYD than the Harshaw catalyst. This suggests that the active sites for conventional oxide catalyst have a lower intrinsic activity compared to Harshaw $0402 \mathrm{~T}$ which is promoted by cobalt.

The TPD profiles for unsupported ATTM are shown in Figure 4.27. Two peaks have been found for ATTM thermal decomposition in He followed by TPR in hydrogen. The un-finished plot seems to show another peak at higher temperatures.

\subsection{Cobalt-Promoted Molybdenum Catalyst}

Molybdenum based catalysts are usually promoted with cobalt or nickel. A vast amount of literature exists on interactions between $\mathrm{MoS}_{2}$ and promoters. But there does not appear to be any studies on catalyst activity of Co-promoted molybdenum catalysts prepared by the decomposition of the corresponding thiosalt.

\subsubsection{Temperature-Programmed Reduction}

Temperature-programmed reduction is a valuable technique in the study of molybdenum and Co-promoted molybdenum catalysts. The supported cobalt tetrathiomolybdate (CTTM), prepared as described in Chapter 3 , was subjected to TPR. About $0.2 \mathrm{~g}$ of $\mathrm{CTTM} / \mathrm{Al}_{2} \mathrm{O}_{3}$ was placed in the microreactor and decomposed in He at $10^{\circ} \mathrm{C} / \mathrm{min}$ to $450^{\circ} \mathrm{C}$, and the sample was thereafter held at that temperature for 15 minutes. After cooling to room temperature, it was heated in hydrogen at $15^{\circ} \mathrm{C} / \mathrm{min}$ to $550^{\circ} \mathrm{C}$. The resulting TPR profile is shown in Figure 4.28, along with the TPR profile of molybdenum sulfide, prepared by $10^{\circ} \mathrm{C} / \mathrm{min}$ thermal decomposition of $\mathrm{ATTM} / \mathrm{Al}_{2} \mathrm{O}_{3}$ in a similar manner.

The two TPR profiles in Figure 4.28 differ significantly. For the same molybdenum loading, the total amount of $\mathrm{II}_{2} \mathrm{~S}$ evolved from cobalt-molybdenum is $58.2 \mathrm{~mL} / \mathrm{g}$, which is 


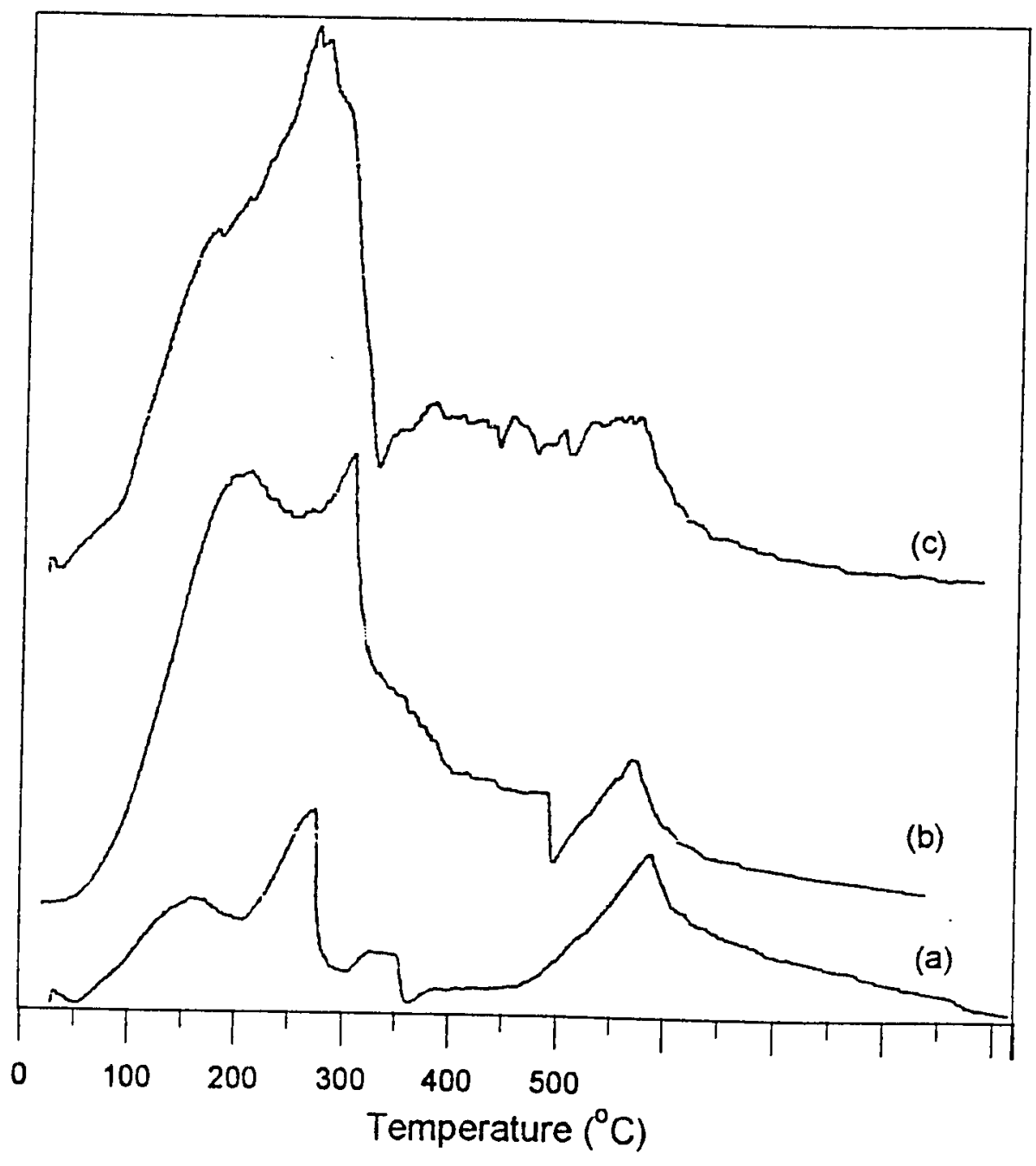

Figure 4.26: Effect of preparation technique on TPD profile. Catalyst Weight $=0.2 \mathrm{~g}$. (a) Harshaw 0402T: Reductive sulfiding + TPR. (b) $\mathrm{MoO}_{3} / \mathrm{Al}_{2} \mathrm{O}_{3}$ : Reductive sulfiding + TPR. (c)ATTM $/ \mathrm{Al}_{2} \mathrm{O}_{3}: \mathrm{H}_{2}$ reduction 

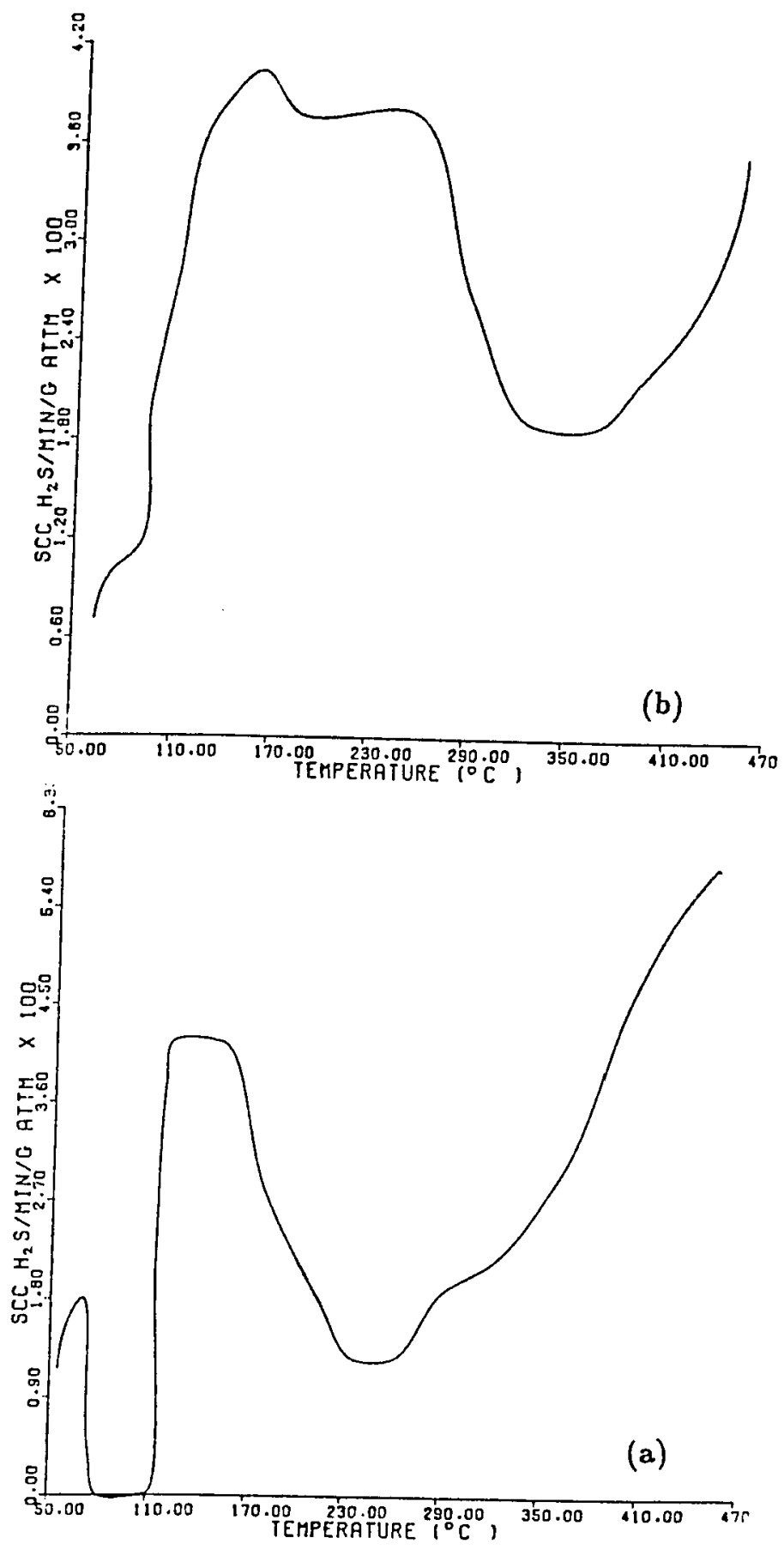

Figure 4.27: TPD profiles for unsupported ATTM (a) flash decomposition (b) $10^{\prime \prime} \mathrm{C} / \mathrm{min}$ decomposition, in He followed by TPR [Kalthod, 1985] 


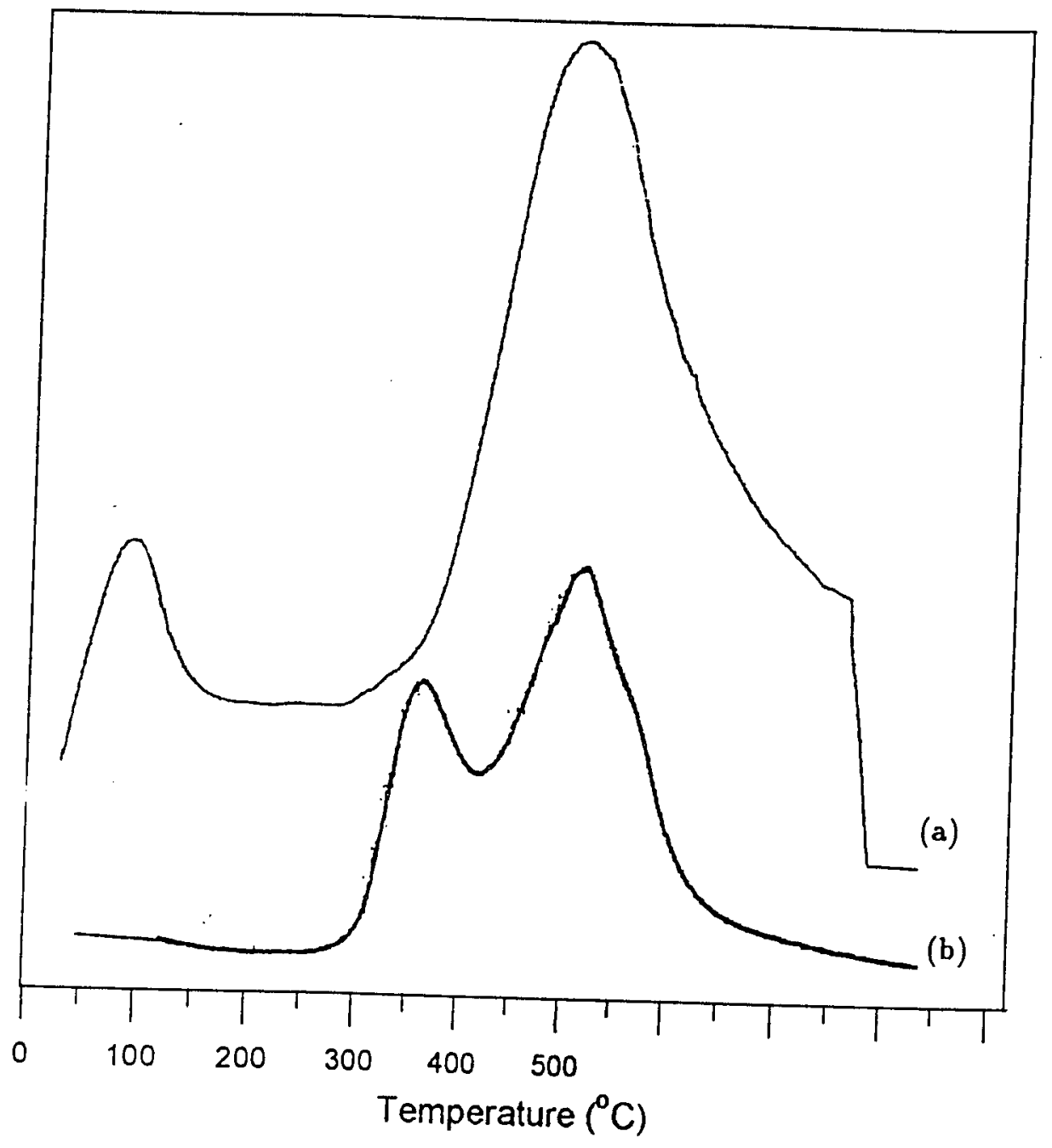

Figure 4.28: TPR profiles for Co-promoted and unpromoted molybdenum sulfide catalysts (a) $\mathrm{CoMo} / \mathrm{Al}_{2} \mathrm{O}_{3}$ (b) $\mathrm{Mo} / \mathrm{Al}_{2} \mathrm{O}_{3}$ 
almost twice that evolved from molybdenum sulfide $(24.5 \mathrm{~mL} / \mathrm{g})$. The greater $\mathrm{H}_{2} \mathrm{~S}$ evolution from the cobalt-molybdenum sulfide reflects the greater amount of residual sulfur remaining after thermal decomposition of CTTM. Thermal decomposition of ATTM causes more sulfur loss due to the formation of $\mathrm{H}_{2} \mathrm{~S}$ as a product. The sulfur removal of CTTM and ATTM during thermal decomposition in He was discussed in section 3.1.

The TPR profile of cobalt-molybdenum sulfide shows two distinct peaks at about $95^{\circ} \mathrm{C}$ and $430^{\circ} \mathrm{C}$, respectively. This is in agreement with the observation by Scheffer et al. [44] for the $\mathrm{CoMo} / \mathrm{Al}_{2} \mathrm{O}_{3}$ with the similar loading. In their study, for Co loadings lower than $3.2 \%$, two $\mathrm{H}_{2} \mathrm{~S}$ peaks were observed at $82^{\circ} \mathrm{C}$ and $827^{\circ} \mathrm{C}$, but no clear peaks were seen between these two peaks. However, at higher loadings of $\mathrm{Co}$, a broad peak of $\mathrm{H}_{2} \mathrm{~S}$ was observed between the two peaks, and at the highest loading a sharp peak developed which resulted in the TPR profile having 3 distinct peaks.

The first peak of the CoMo/ $\mathrm{Al}_{2} \mathrm{O}_{3}$ TPR profile occurs at a much lower temperature compared with the $\mathrm{Mo} / \mathrm{Al}_{2} \mathrm{O}_{3}$ catalyst. This is because the formation heat of the sulfide per mole of Co is lower than that of Mo [16]. The first peak in the TPR profile may correspond to the loss of sulfur bound to Co atoms only. The second peak of the CoMo/ $\mathrm{Al}_{2} \mathrm{O}_{3}$ TPR profile is in the same temperature region corresponding to the first and second TPR peaks of the $\mathrm{Mo} / \mathrm{Al}_{2} \mathrm{O}_{3}$, and it is broader than the TPR peaks of the Mo catalyst, therefore the second peak of the $\mathrm{CoMo} / \mathrm{Al}_{2} \mathrm{O}_{3}$ catalyst may correspond to the loss of sulfur bound to Mo atoms including both surface and bulk. Based on their experiments, Scheffer et al. [44] suggested that the reduction occurring between $354-654^{\circ} \mathrm{C}$ is largely attributed to hydrogenation of $\mathrm{S}$ from $\mathrm{MoS}_{2}$-like species. No cobalt sulfide species are reduced at this temperature, and the high temperature side of the Mo catalyst reduction peak disappears due to the reduction of Co spinel phase. This agrees with our observations for the supported Co-promoted catalyst.

The TPR profile for un-supported Co-promoted ATTM was studied by Kalthod and Weller [17]. The resulting TPR profile, along with the TPR profile of a unpromoted molybdenum catalyst pretreated in a similar manner, are shown in Figure 4.29. Three distinct 


\begin{tabular}{||c|c|c|c|c|c||}
\hline catalyst & $\begin{array}{c}\text { LTOC } \\
(\mathrm{mL} / \mathrm{g})\end{array}$ & $\begin{array}{c}\text { BET area } \\
\left(\mathrm{m}^{2} / \mathrm{g}\right)\end{array}$ & $\begin{array}{c}\text { TPD } \\
(\mathrm{mL} / \mathrm{g})\end{array}$ & $\begin{array}{c}\text { HYD Conv. } \\
(\text { At } \mathrm{t}=3 \mathrm{hr}, \%)\end{array}$ & $\begin{array}{c}\text { HDS Conv. } \\
(\text { Ave. \%) }\end{array}$ \\
\hline CTTM $/ \mathrm{Al}_{2} \mathrm{O}_{3}$ & 2.31 & 155 & 15.4 & 30.3 & 54.1 \\
$\mathrm{ATTM} / \mathrm{Al}_{2} \mathrm{O}_{3}$ & 1.42 & 183 & 15.0 & 28.9 & 13.5 \\
\hline
\end{tabular}

Table 4.12: The Comparison of Co-promoted and Unpromoted ATTM/Al $\mathrm{Al}_{2} \mathrm{O}_{3}$

peaks occurred at 247,376 and $412^{\circ} \mathrm{C}$, respectively. The second peak appears as a left shoulder to the third peak. The total amount of $\mathrm{H}_{2} \mathrm{~S}$ evolved from CoMo/ $\mathrm{Al}_{2} \mathrm{O}_{3}$ is twice that evolved from molybdenum sulfide, which matches our observation.

\subsubsection{Effect of Cobalt on the Activity of $\mathrm{Mo} / \mathrm{Al}_{2} \mathrm{O}_{3}$}

The effect of promoter Co added on $\mathrm{Mo} / \mathrm{Al}_{2} \mathrm{O}_{3}$ prepared by the impregnation of ATTM $/ \mathrm{Al}_{2} \mathrm{O}_{3}$ with cobalt nitrate solution was studied with the help of BET surface area, oxygen chemisorption, and HDS and HYD activities.

LTOC, BET values and propylene HYD, thiophene HDS conversions for promoted and unpromoted catalysts are shown in Table 4.12. The results of ATTM/ $\mathrm{Al}_{2} \mathrm{O}_{3}$ runs with similar pretreatment are also shown in Table 4.12 for comparison.

It can be seen that the BET surface area of molybdenum catalyst decreases considerably due to the addition of a promotor. After impregnating the dry $\mathrm{ATTM} / \mathrm{Al}_{2} \mathrm{O}_{3}$ catalyst in aqueous nitrate solutions, it is expected that BET area decreases due to the decomposition of promoters on the sulfides.

The propylene HYD conversion during a 5 hour reaction period and the thiophene HDS conversion during a 3.5 hour reaction period are shown in Figure 4.30 and 4.31 , respectively. It was observed that, for the Co-promoted catalyst, the HDS activity increased significantly, but the HYD activity was very similar compared to the un-promoted catalyst. Reddy [39] and co-workers proposed that for HDS reactions, Co as a promoter changes the 


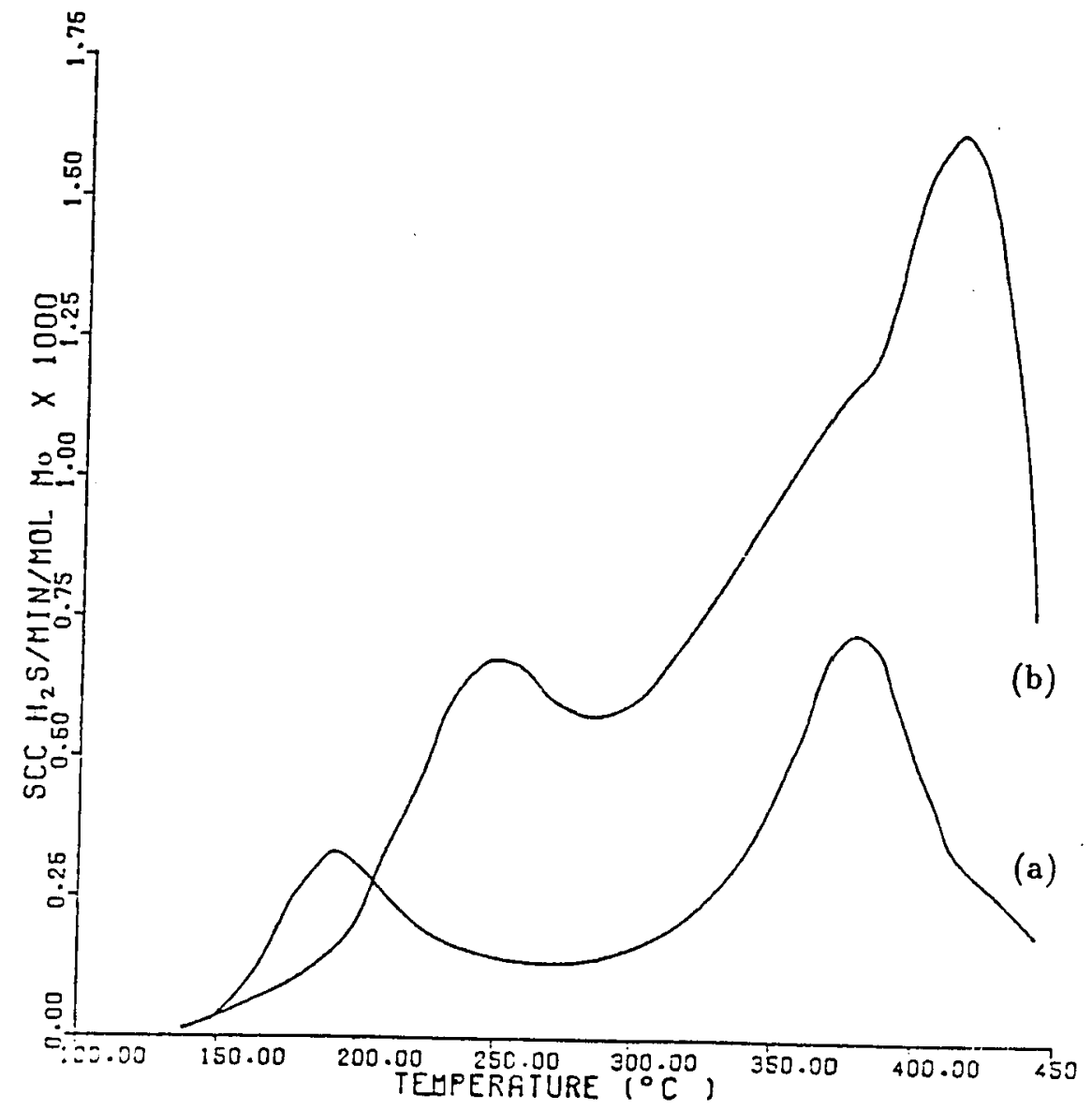

Figure 4.29: TPR profiles for unsupported (a) unpromoted ATTM (b) Co-promoted ATTM [Kalthod, 1985] 
intrinsic activity of the HDS sites by altering the electron density around Mo. Therefore, the promoted catalysts have a higher HDS activity per site (CUS) than the un-promoted catalyst. But unlike the HDS sites, the promoter does not alter the intrinsic activity of the HYD sites. Therefore the HYD reaction appears to be a function of the number of active sites only, which is in agreement with our observation.

The thiophene HDS conversions in Table 4.12 are lower than the data presented in Table 4.4 due to the lower thiophene concentration in the reactant. The reactant concentrations were maintained at the same level for each set of runs to ensure a proper comparison.

Low temperature oxygen chemisorption was measured as shown in Table 4.12. The oxygen uptake of promoted molybdenum catalyst was higher compared to the un-promoted catalyst. Since the HYD activity of Co-promoted catalyst was not higher than the unpromoted catalyst, it can be concluded that LTOC does not correlate well with HYD activity for the Co-promoted catalyst.

The TPD profiles and $\mathrm{H}_{2} \mathrm{~S}$ evolution values of supported Co-promoted and unpromoted ATTM are shown in Figure 4.32 and Table 4.12. It is clear that the $\mathrm{H}_{2} \mathrm{~S}$ evolution of Copromoted catalyst is almost the same as for unpromoted catalyst. This suggests that cobalt promotion does not increase the anion vacancies in the surface. Regarding the promotion role of cobalt in HDS catalysts, some workers claim that cobalt increases the number of active sites [22], while others favor the idea that cobalt does not affect the number of active sites but promotes the intrinsic activity of the sites $[40,28,58]$. Based on our observation for TPD and HDS/HYD activities, it can be concluded that cobalt as a promoter affects the intrinsic activity (increases HDS, not HYD activity) rather than the number of active sites.

The effect of preparation technique on Co-promoted catalysts is shown in Figure 4.33. Propylene HYD activities of the two catalysts prepared by Co-promoted ATTM $/ \mathrm{Al}_{2} \mathrm{O}_{3}$ and Co-promoted $\mathrm{MoO}_{3} / \mathrm{Al}_{2} \mathrm{O}_{3}$ are compared. Co- $\mathrm{MoO}_{3} / \mathrm{Al}_{2} \mathrm{O}_{3}$ was prepared by CTTM calcination at $500^{\circ} \mathrm{C}$ for 12 hours, and it therefore had the same Mo loading as CoATTM $/ \mathrm{Al}_{2} \mathrm{O}_{3}$. It was observed that for the same catalyst weight and pretreatment, Co- 


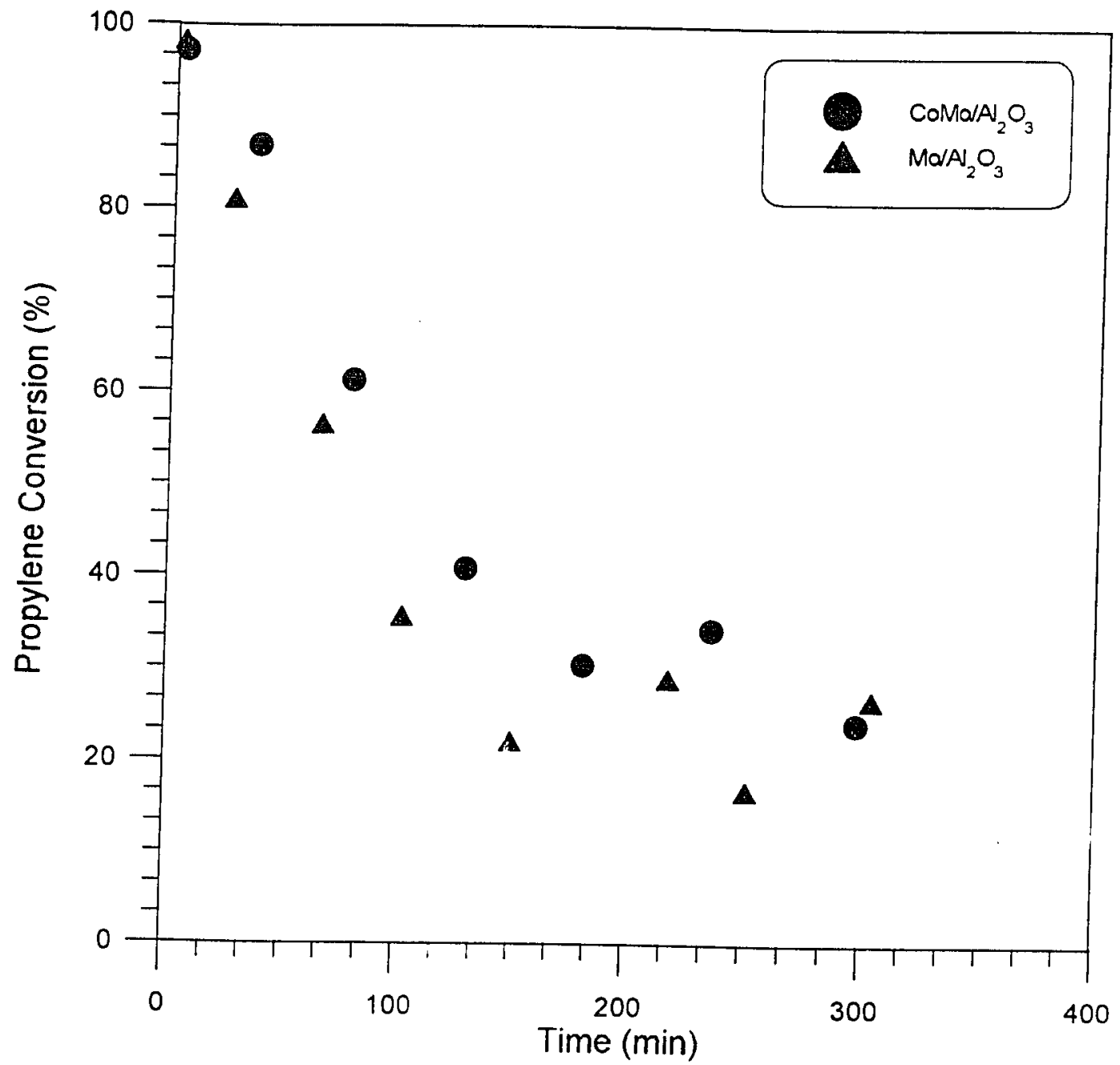

Figure 4.30: Propylene HYD activity for Co-promoted and unpromoted catalysts. Catalyst Weight $=0.08 \mathrm{~g} . \mathrm{T}=50^{\circ} \mathrm{C} . \mathrm{H}_{2}: \mathrm{C}_{3} \mathrm{H}_{5}=1.5: 1$. Catalysts prepared by thermal decomposition of CTTM and ATTM in He at $10^{\prime \prime} \mathrm{C}$ 'min followed by TPR. 


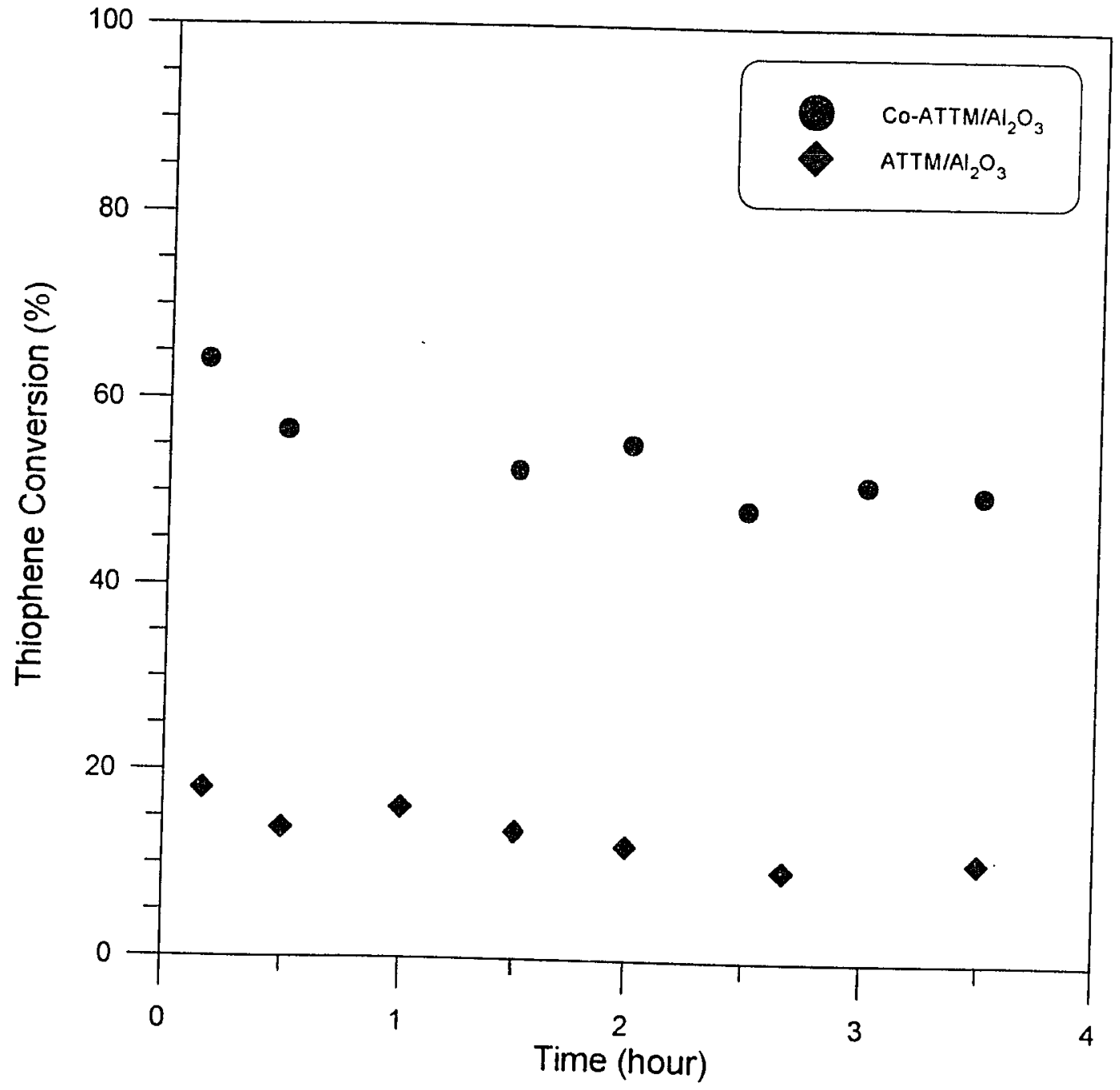

Figure 4.31: Thiophene HDS activity for Co-promoted and unpromoted catalysts. Catalyst Weight $=0.2 \mathrm{~g}$. Catalysts prepared by thermal decomposition of CTTM and ATTM in He at $10^{\prime \prime} \mathrm{C} / \mathrm{min}$ followed by $\mathrm{TPR}$.

74 


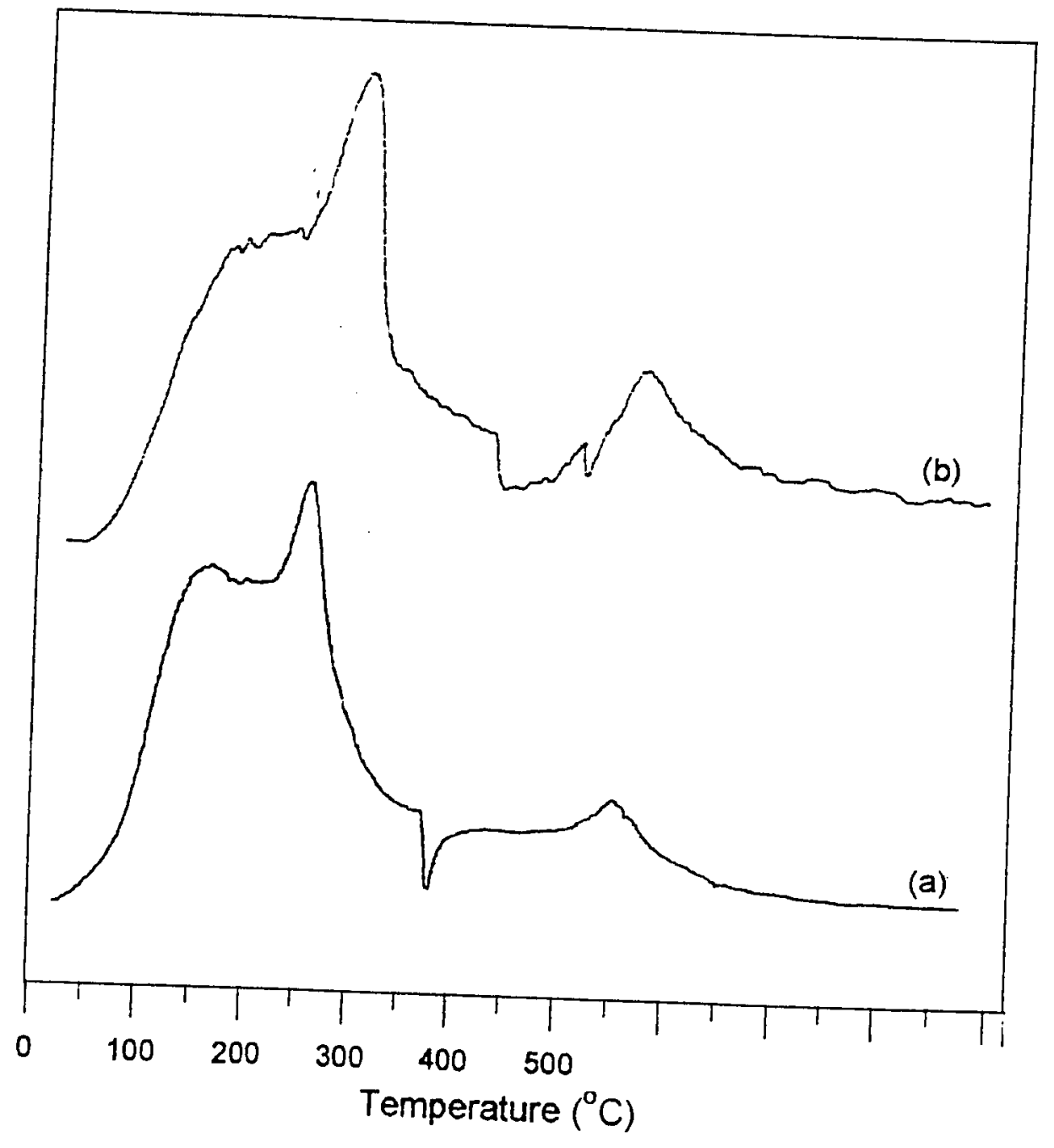

Figure 4.32: TPD profiles for Co-promoted and unpromoted sulfide molybdenum catalyst. Catalyst Weight $=0.2$ g. (a) $\mathrm{Mo}_{2} / \mathrm{Al}_{2} \mathrm{O}_{3}$ (b) $\mathrm{CoMo} / \mathrm{Al}_{2} \mathrm{O}_{3}$ 
promoted ATTM $/ \mathrm{Al}_{2} \mathrm{O}_{3}$ had a much higher activity compared to the conventional oxide catalyst. The extent of reduction of the Co-promoted ATTM/ $/ \mathrm{Al}_{2} \mathrm{O}_{3}$ has not been reported in the literature. But judging by the previous results for the catalysts prepared by the decomposition of ATTM in hydrogen, one can assume that the valence state of the catalyst prepared from Co-promoted ATTM/ $\mathrm{Al}_{2} \mathrm{O}_{3}$ would probably be lower than the valence state of a Co-promoted conventional oxide, which would therefore result in more surface anion vacancies leading to a higher activity. The experimental results support this assumption.

\subsection{Catalyst Stability}

One of the inherent problems for ATTM is that the catalyst turns dark, upon exposure to air, and thus loses a good deal of activity. In order to understand the reason for the color change, an IR spectroscopy study was conducted between 450 to $4000 \mathrm{~cm}^{-1}$. The IR plots for a freshly prepared ATTM sample and an exposed ATTM sample are shown in Figures 4.34 and 4.35 , respectively. Compared to freshly prepared ATTM, the ATTM exposed to air for 48 hours has extra peaks at wavenumbers less than $1400 \mathrm{~cm}^{-1}$, which may indicate the presence of oxysulfides.

In our experiments, the problem was circumvented by carrying out the impregnation under a $\mathrm{N}_{2}$ blanket, and storing the catalyst in a vacuum desiccator. The decomposition of ATTM was performed in-situ. In order to eliminate the formation of oxysulfides for larger scale storage and transportation, different additives and various mixing ratios of additive in catalyst were tried in this study.

A process comprising the protection of metal catalysts from being oxidized was developed by Chevron Research Company [45]. The process consisted of introducing a protective material into the pores of the catalyst. Stearic acid, dodecane, paraffin wax, and microcrystalline wax were used as protective materials. Another technique used in the polymer industry to add antioxidants to prevent oxidative degradation of the polymer was also used as a trial.

Freshly prepared ATTM has a dark crimson color. When this material is oxidized, 


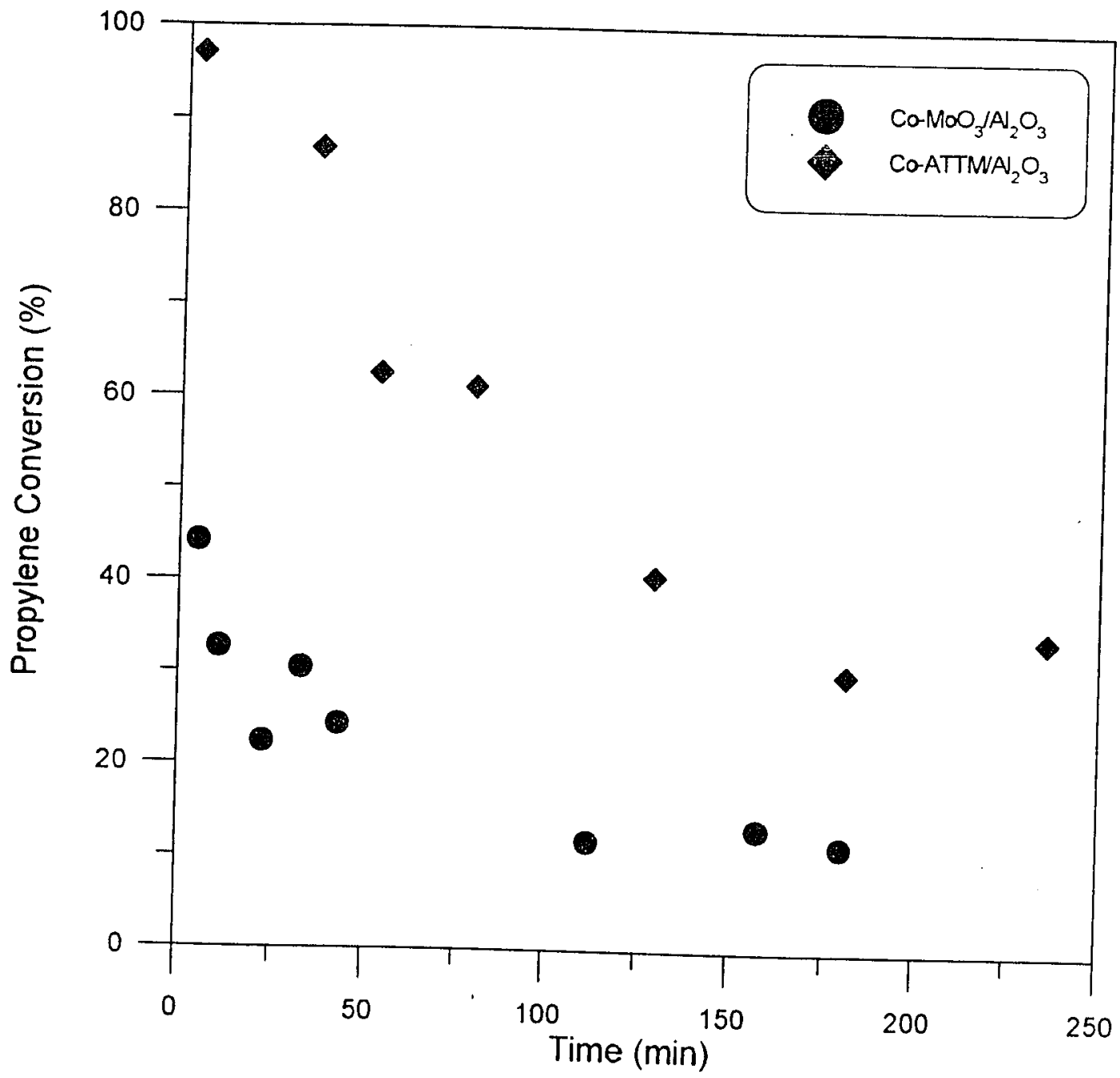

Figure 4.33: Propylene HYD activity for Co-promoted ATTM/Al. $\mathrm{O}_{3}$ and Co-promoted $\mathrm{MoO}_{3} / \mathrm{Al}_{2} \mathrm{O}_{3}$. Catalyst Weight $=0.08$ g. $\mathrm{T}=50^{\circ} \mathrm{C} . \mathrm{H}_{2}: \mathrm{C}_{3} \mathrm{H}_{6}=1.5: 1$. Catalysts prepared by (a) thermal decomposition of CTTMI in He at $10^{\circ} \mathrm{C} / \mathrm{min}$ followed by TPR.(b) Co- $\mathrm{MoO}_{3} / \mathrm{Al}_{2} \mathrm{O}_{3}$ prepared by reductive sulfiding followed by TPR 


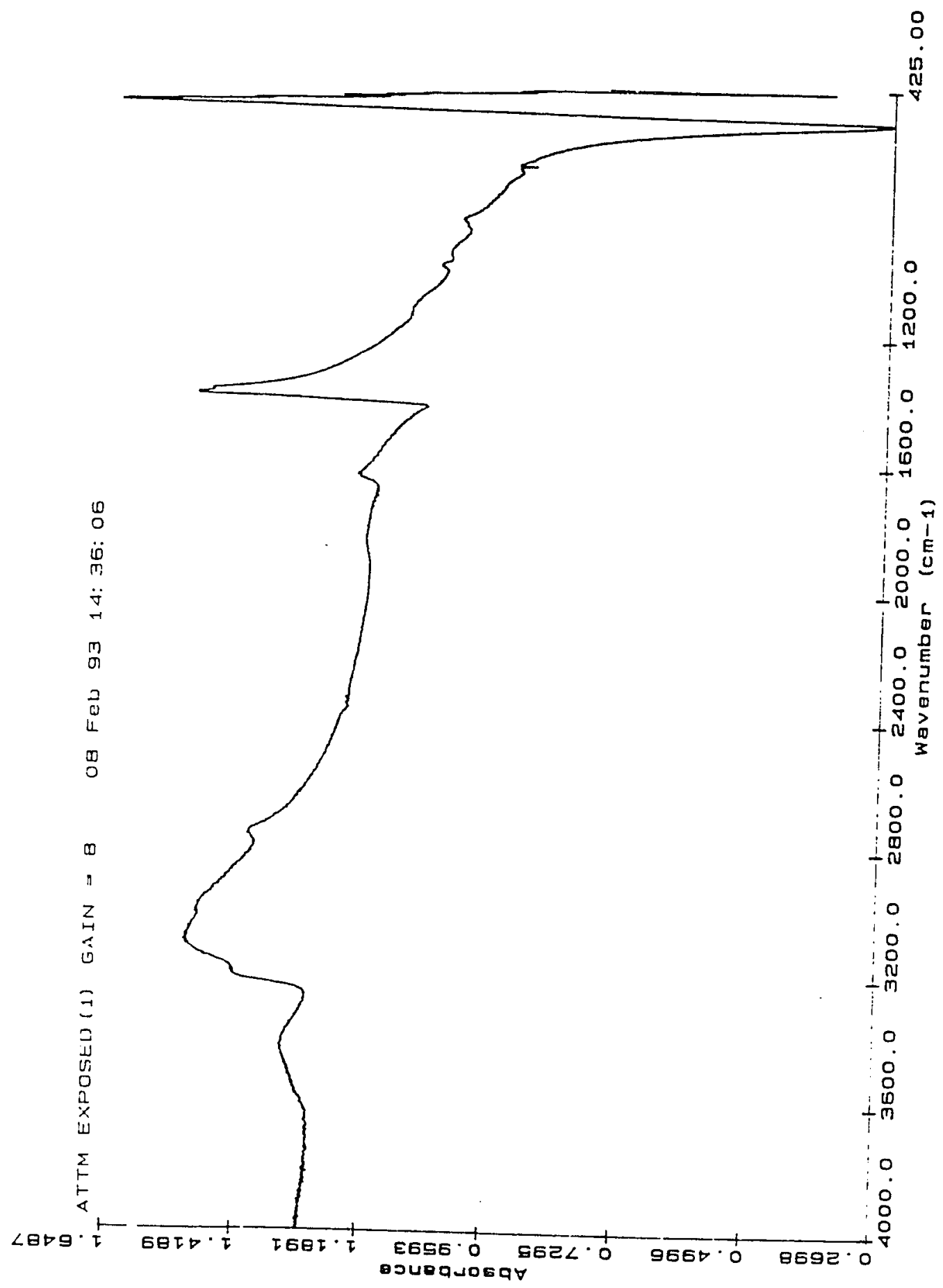

Figure 4.34: IR spectrum of freshly prepared ATTM 


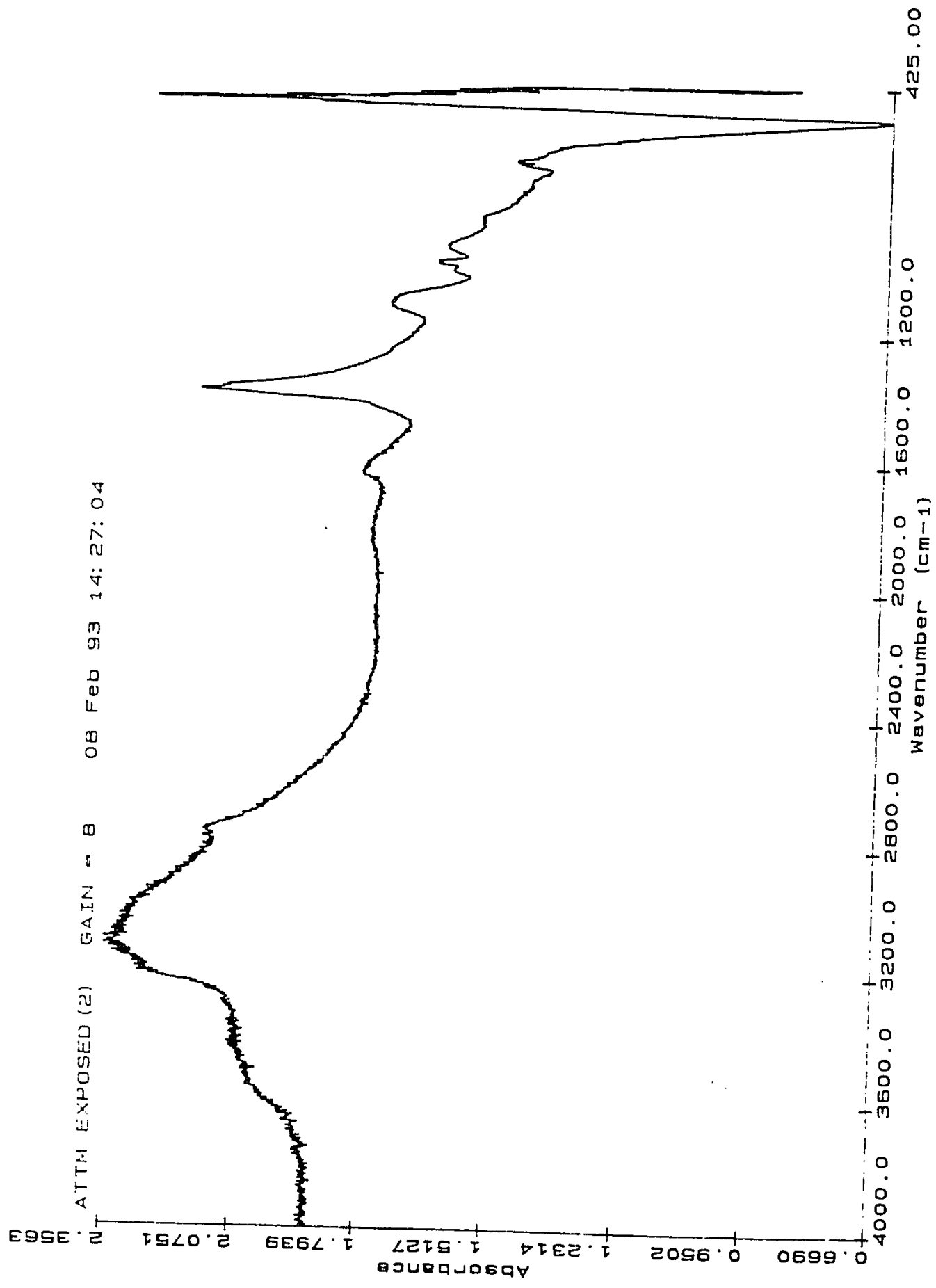

Figure 4.35: IR spectrum of ATTM exposed to air for 48 hours 


\begin{tabular}{||c|c|c|c|c||}
\hline Run & $\begin{array}{c}\text { Stearic acid/Acetone } \\
(\text { mole/mole })\end{array}$ & $\begin{array}{c}\text { Exposure Time } \\
(\mathrm{hr})\end{array}$ & Wet/Dry & Color \\
\hline 1 & $0.0 / 2.0$ & 48 & $\mathrm{dry}$ & black \\
2 & $3.5 \times 10^{-3} / 2.0$ & 24 & $\mathrm{dry}$ & black \\
3 & $3.5 \times 10^{-3} / 1.0$ & 24 & $\mathrm{wet}$ & crimson \\
3 & $1.0 / 1.0$ & 48 & $\mathrm{dry}$ & crimson \\
4 & $2.0 / 1.0$ & 48 & $\mathrm{dry}$ & crimson \\
5 & $3.0 / 1.0$ & 48 & $\mathrm{dry}$ & crimson \\
\hline
\end{tabular}

Table 4.13: ATTM Stability Study

it turns from crimson to a dull black color. The color change was used as a qualitative indication of the oxidization of ATTM in our trials.

The experimental measurements in which stearic acid was used as a protective liquid are listed in Table 4.13. For a blank run, or at low stearic acid concentrations (Run 1, 2 and 3), ATTM turned black when the acetone evaporated during the exposure. This suggests that the crimson color in Run 3 could be a result of the physical barrier offered by the solution, which limits the diffusion of oxygen from the air to the ATTM. At higher stearic acid concentrations (Run 3,4 and 5), the crimson color remained even when the acetone evaporated during the exposure. This suggests that the stearic acid molecules might act as "oxygen receivers" or "oxygen scavengers" in the mixture and therefore protect the ATTM from getting oxidized.

Trials with antioxidants, such as Irganox, were not successful. 


\section{Chapter 5}

\section{CONCLUSIONS AND RECOMMENDATIONS}

\subsection{Conclusions}

\section{Experiment and Measurement}

$\mathrm{MoS}_{2}$ catalyst reacts readily with oxygen and must be prepared in-situ to assure an oxygen free atmosphere. An integrated microreactor system to perform low temperature chemisorption, temperature-programmed adsorption and desorption, and activity measurements in-situ was designed and constructed.

Oxygen chemisorption was measured by a pulse method at $-78^{\circ} \mathrm{C}$. This method was selected because it is sensitive and rapid.

The activity was measured by both a continuous method and a pulse method. It was shown for the first time, that thiophene activity measured by the pulse method agreed well with that measured by a continuous method.

\section{Temperature-Programmed Reduction}

Temperature-programmed reduction yields information about the nature of the initial catalyst prepared by thermal decomposition of ATTM in He. The TPR profiles showed two peaks at about $380^{\circ} \mathrm{C}$ and $530^{\circ} \mathrm{C}$, which is much higher than the peak temperatures for unsupported ATTM at $180^{\circ} \mathrm{C}$ and $380^{\circ} \mathrm{C}$. The first TPR peak is larger for a $10^{\circ} \mathrm{C} / \mathrm{min}$ - 
decomposed sample than for a flash-decomposed sample, but the second peak was roughly the same height for both. This is similar to what was observed for unsupported ATTM.

For unsupported ATTM, sintering was observed at temperatures above $250^{\circ} \mathrm{C}$ and became severe at temperature above $450^{\circ} \mathrm{C}$. In contrast to unsupported ATTM, the negligible sintering was observed for supported ATTM during the TPR (up to $550^{\circ} \mathrm{C}$ ) indicating that the catalyst is stabilized by interaction with the support.

\section{$\underline{\text { Pretreatment and Activity }}$}

LTOC data indicated that the catalyst prepared by flash decomposition of ATTM is basal plane-rich while that prepared by $10^{\circ} \mathrm{C} / \mathrm{min}$ decomposition is edge plane-rich. Even though the catalysts have different BET area and oxygen chemisorption, their activity for propylene HYD are almost the same. This indicates that the catalyst morphology has little effect on HYD activity. The thiophene HDS activity and LTOC value for the $10^{\circ} \mathrm{C} / \mathrm{min}$ decomposed sample was higher than that of the flash-decomposed sample. This suggests that the thiophene HDS reaction probably occurs on edge planes, whereas HYD and HDS reactions may have different active sites.

Progressive increases in the HDS and HYD activity were observed as sulfur was lost during TPR. This may be attributed to non-stoichiometric sulfur atoms blocking CUS-Mo sites at the crystallite edges at lower temperatures.

\section{Valence State and Activity}

An important assumption made in this dissertation is that the lower valence state of Mo results in a higher concentration of anion vacancies and therefore results in higher activities. HDS/HYD activity, LTOC, and TPD measurements for the catalysts prepared by $\operatorname{ATTM}(\mathrm{CTTM}) / \mathrm{Al}_{2} \mathrm{O}_{3}$ strongly support this hypothesis.

The valence state for supported molybdenum catalysts prepared by thermal decomposition in helium followed by TPR has not been reported in literature. If the above hypothesis is true, they may have valence states higher than that of a $\mathrm{H}_{2}$ reduction sample, but lower 
than 2.

\section{Oxygen Chemisorption}

The flash-decomposed sample has a lower LTOC value than the $10^{\circ} \mathrm{C} / \mathrm{min}$-decomposed sample after TPR. This suggests that temperature-programmed sample may have a higher amount of edge plane, which acts as the site for oxygen chemisorption.

Oxygen chemisorption increases with reduction temperature. The initial catalyst prepared by ATTM decomposition in He has negligible oxygen chemisorption. Considerable oxygen chemisorption occurs after removal of sulfur corresponding to the first TPR peak; i.e., the reduction at $420^{\circ} \mathrm{C}$. The highest LTOC was obtained for samples in which TPR was conducted to $550^{\circ} \mathrm{C}$.

For the catalysts prepared by $\mathrm{ATTM} / \mathrm{Al}_{2} \mathrm{O}_{3}$, oxygen chemisorption was found to be directly correlated with HDS activities; i.e., the higher the LTOC value, the higher was the HDS activity, except in the case of a sample prepared by $\mathrm{H}_{2}$ reduction. However, for Co-promoted ATTM/ $\mathrm{Al}_{2} \mathrm{O}_{3}$, oxygen chemisorption does not correlate well with $\mathrm{HYD}$ activity.

\section{Sulfur Anion Vacancies}

The correlation between HDS/HYD activity, and anion vacancies generated by desorption of $\mathrm{H}_{2} \mathrm{~S}$ on supported $\mathrm{MoS}_{y}$ was studied. It was observed that a high $\mathrm{H}_{2} \mathrm{~S}$ value in TPD corresponds to a high HDS/HYD activity for the most part. The catalyst prepared by flash decomposition followed by TPR has a high amount of surface anion vacancies, but low activity probably due to its low proportion of edge sites.

The ratio of $\mathrm{H}_{2} \mathrm{~S}$ evolved/LTOC varied depending on the catalyst morphology and extent of $\mathrm{H}_{2} \mathrm{~S}$ desorption. The ratio is expected to be 2 if oxygen is chemisorbed at all vacancies. The higher value suggests that a particular geometrical configuration of vacancies is required to absorb oxygen. 


\section{Comparison of Supported and Unsupported ATTM}

Strong similarities were observed between supported and unsupported ATTM catalysts as evident from TPR/TPD profiles, effect of pretreatments on morphology and activities. The observations support the assumption that $\mathrm{MoS}_{2}$-like hexagons exist as two-dimensional slabs about a layer thick on the support for supported molybdenum catalysts. The dissimilarities, such as higher thermal stability, and higher order of magnitude of LTOC, TPR, and TPD values for supported ATTM are due to the stabilization and better catalyst distribution of the supported catalyst.

\section{Cobalt-promoted Molybdenum sulfide catalyst}

The cobalt tetrathiomolybdate (CTTM) was $10^{\circ} \mathrm{C} / \mathrm{min}$-decomposed in He and subjected to TPR in $\mathrm{H}_{2}$ as was done for ATTM. The TPR profile showed 2 distinct peaks centered at $95^{\circ} \mathrm{C}$ and $430^{\circ} \mathrm{C}$. It is conjectured that the first peak corresponds to the loss of $\mathrm{S}$ atoms bonded to Co atoms only and the second peak corresponds to loss of $\mathrm{S}$ atom bonded to Mo atoms only.

The amount of $\mathrm{H}_{2} \mathrm{~S}$ evolved from the cobalt molybdenum sulfide during TPR is 58.2 $\mathrm{mL} / \mathrm{g}$ which is about twice that evolved from the molybdenum sulfide $(24.5 \mathrm{~mL} / \mathrm{g})$. This reflects the greater residual amount of sulfur remaining after the thermal decomposition of CTTM.

The amount of $\mathrm{H}_{2} \mathrm{~S}$ evolved during TPD is $15.4 \mathrm{~mL} / \mathrm{g}$ for $\mathrm{Co}-\mathrm{Mo} / \mathrm{Al}_{2} \mathrm{O}_{3}$ which is almost the same as $15.0 \mathrm{~mL} / \mathrm{g}$ for $\mathrm{Mo} / \mathrm{Al}_{2} \mathrm{O}_{3}$ subjected to the same pretreatment. This suggests that cobalt promotion does not increase the amount of anion vacancies.

\subsection{Recommendations}

Many questions regarding the surface structure and active sites of catalysts still remain. Our research clearly demonstrates that we have a superior catalyst. But instrumental measurements of the surface will significantly add to the understanding of the nature of the 
catalytic sites. Topsoe [48] used infrared analysis in conjunction with NO chemisorption and demonstrated that uncoordinated Mo and Co adsorption sites could be determined. Therefore, FTIR results can be used to correlate catalytic activities to the number of vacancies present. ESCA and Raman may shed more light on the nature of the surface. 


\section{BIBLIOGRAPHY}

[1] Anderson, A. B., Al-Saigh, S. Y., and Hall, W. K., J. Phys. Chem. 92, 803 (1988).

[2] Bodrero, T. A., and Bartholomew, C. H., J. Catal. 84, 145 (1983).

[3] Candia, R., Clausen, B. S., Bartholdy, J., Topsoe, N., Lengeler, B., Topsoe, H., Proc. 8th International Congr. Catal. 2, 375 (1984).

[4] Chang, H. and Weller, S.W., Ind. Eng. Chem. Process Des. Dev. Vol.17, No.3, (1978).

[5] Chianelli, R. R., et al., Amer. Chem. Soc. Petrol. Prepr. 35, 227 (1990).

[6] Chianelli, R. R., Puppert, A. F., Behal, S.K., Kear, B. H., et al., J. Catal. 92, 56 (1985).

[7] Duncombe, P.R., and Weller, S. W., AIChE J. Vol.31, No.3, 410 (1985).

[8] Ekman, M. E., Anderegg, J. W., and Schrader, G. L., J. Catal. 117, 246 (1989).

[9] Farias, M. H., Gellman, A. J., Somorjai, G.A., Chianelli, R. R., and Liang, K. S., Surf. Sci 140, 181 (1984).

[10] Fierro, J. L. G., Gonzalez Tejuca, L., Lopez Agudo, A., and Weller, S. W., J. Catal. $89,111(1984)$.

[11] Freel, J., J. Catal. 25, 139 (1972).

12 Goldwasser, J., Fang: S. M., Houalla, M., and Hall, W. K., J. Catal. 115, 34 (1989).

[13' Hall, W. K.,Chem. Uses Molybenum, Proc. 4th Int. Conf., (1982) 224.

14] Hung, W., M. S. Thesis, SUNY' at Buffalo, 1983. 
[15] Jalowiecki-Duhamel, L., Grimblot, J. and Bonnelle, J.P., J. Catal. 129, 511 (1991).

[16] Kalthod, D. G., PhD. Thesis, SUNY at Buffalo, 1985.

[17] Kalthod, D. G., and Weller, S. W., J. Catal. 95, 455 (1985).

[18] Kalthod, D. G., and Weller, S. W., J. Catal. 98, 572 (1986).

[19] Kasztelan, S., Wambeke, A., Jalowiecki, L., Grimblot, J and Bonnelle, J. P., J. Catal. $124,12(1990)$.

[20] Knozinger, H., "Proceedings, 9th International Congress on Catalysis, Calgary 1988" (M. J. Phillips and M. Ternan, Eds.), Vol.5, p. 20 (1988).

[21] Kokes, R. J., Tobin, H., and Emmett, P. H., J. Am. Chem. Soc. 77, 5860 (1955).

[22] Kraus, M. and Vyskocil. V., Collect. Czech. Chem. Commun. 44, 3676 (1979).

[23] Laine J., Brito J. L., and Severino, F., J. Catal. 131, 385 (1991).

[24] Lombardo, E. A., LoJacano, M., and Hall, W. K., J. Catal. 64, 150 (1980).

[25] Liu, H. and Weller, S. W., J. Catal. 66, 65 (1980).

[26] Massoth, F. E., J. Catal. 36, 164 (1975).

[27] Massoth, F. E., and Kibby, C. L., J. Catal. 47, 300 (1977).

[28] Miciukiewicz, J., Zmierczak, W., and Massoth, F. E., Bull. Soc. Chim. Belg. 96, 915 (1987).

[29] Millman, W.S., and Hall, W. K., J. Catal. 59, 311(1979).

[30] Moon, S. J., Ihm, S. K., Appl. Calal. 42, 307 (1988).

[31] Muller, A., Diemann, E. Branding, A., Baumann, F. W., Breysse, M. and Vrinat, M., Appl. Catal., 62, L13 (1990). 
[32] Naumann, A. W., Behan, A. S., and Thorsteinson, E. M., Proc. 4th Intern. Conf. The Chemistry and Uses of Molybdenum, Golden, Colorado (1982).

[33] Parekh, B. S. and Weller, S. W., J. Catal. 47, 100 (1977).

[34] Parekh, B. S., and Weller, S. W., J. Catal. 55, 58 (1978).

[35] Polz, J., Zeilinger, H., Muller, B., and Knozinger, H., J. Catal. 120, 22 (1989).

[36] Radomyski, B., Szczygie, J., and Trawczynski, J., Appl. Catal. 25, 295 (1986).

[37] Ramanathan, K., and Weller, S. W., J. Catal. 95, 249 (1985).

[38] Rao, P. K., Prasad, V. V. D. N., Rao, S., and Chary, K. V. R., J. Catal. 142, 121 (1993).

[39] Reddy, B. M., Chary, V. R., Subrahmanyam, V. S., J. Chem. Soc. Faraday Trans. I 81,1655 (1985).

[40] Reddy, B. M., Subrahmanyam, V. S., Appl. Catal. 27, 1 (1986).

[41] Roxlo, C. B., Daage, M., Rupert, A. F., Chianelli, R. R., J. Catal. 100, 176 (1986).

[42] Roxlo, C. B., Deckman, H. W., Gland, J., Cameron, S. D., and Chianelli, R. R., Science 235,1629 (1987).

[43] Salmeron, M., Somorjai, G. A., Wold, A., Chianelli, R. R, and Liang, K. S., J. Catal. 90,105 (1982).

[44] Scheffer, B., Dekker, N.J.J., Mangnus, P.J., Moulijn, J.A., J. Catal. 121, 31 (1990).

[45] Sittig, M., Catalyst Manufacture, Recovery and Use, Noyes Data Corporation, NJ, 1972

[46] Tanaka, K., and Okuhara, T., J. Catal. 78, 155 (1982).

[47] Tauster, S. J., Pecoraro, T. A., and Chianelli, R. R., J. Catal. 63, 515 (1980).

[48] Topsoe, N. Y., and Topsoe, H., J. Catal. 84, 386 (1983). 
[49] Topsoe, H., Clausen, B. S., Topsoe, N. Y., Pedersen, E., Ind. Eng. Chem. Fundam. 25, 25 (1986).

[50] Topsoe, H., Clausen, B. S., Candia, R., Wivel, C., and Morup, S., J. Catal. 68, 433 (1981).

[51] Uchytil, J., Beranek, L., Zahradnikova, H., and Kraus, M., Appl. Catal. 3, 117 (1982).

[52] Valyon, J., and Hall, W. K., J. Catal. 84, 216 (1983).

[53] Valyon, J., and Hall, W. K., J. Catal. 92, 155 (1985).

[54] Vasudevan, P. T., and Weller, S. W., J. Catal. 99, 235 (1986).

[55] Voorhoeve, R. J. H. and Stuiver, J. C. M., J. Catal. 23, 228 (1971).

[56] Vukasovich, M. S., Chemical Data Series, July, 1978.

[57] Weisser, O., and Landa, S., Sulfide Catalysts: Their Properties and Applications Pergammon Tress, New York, 1973.

[58] Zmierczak, W., MuraliDhar, G. and Massoth, F.E., J. Catal. 77, 432 (1982).

[59] Zmierczak, W., Qader, Q., and Massoth, F. E., J. Catal. 106, 65 (1987). 


\section{Appendix A}

\section{LOW TEMPERATURE}

\section{OXYGEN CHEMISORPTION}

The LTOC is measured by injecting pulses of $1.51 \% \mathrm{O}_{2} / \mathrm{He}$ mixture into He carrier gas $(35 \mathrm{~mL} / \mathrm{min})$ flowing through the catalyst bed which was maintained at $-78^{\circ} \mathrm{C}$ by a dry ice-acetone bath. Unadsorbed oxygen is detected by a thermal conductivity detector of a gas chromatograph. The catalyst is assumed to be saturated when successive outlet pulses do not differ by more than $1 \%$.

Example (Run5-38): Low Temperature Oxygen Chemisorption

The peak areas of the outlet pulses are shown in Table A.1

The $\Delta_{i}$ is the fraction of each pulse absorbed by catalyst. It is defined by:

$$
\Delta_{i}=1-\frac{\text { counts }_{(i)}}{\text { counts in final pulse }}
$$

The summation of $\Delta_{i}$ is equal to the total number of "full" pulses adsorbed by catalyst over all the pulses.

The volume of the sampling loop $=5(\mathrm{~mL})$

The amount of $\mathrm{O}_{2}$ per pulse $=0.0151 \times 5=0.0755(\mathrm{~mL} /$ pulse $)$

The summation of $\Delta_{i}=2.700$ (pulse)

The total amount of $\mathrm{O}_{2}$ absorbed $=2.700 \times 0.0755=0.204 \mathrm{~mL}$

The weight of catalyst $=0.2005(\mathrm{~g})$

$$
\mathrm{LTOC}=0.204 / 0.2005=1.02(\mathrm{~mL} / \mathrm{g})
$$




\begin{tabular}{|c|c|c||}
\hline Pulse No. & Peak Area (counts) & $\Delta_{i}$ \\
\hline 1 & 44581 & 0.758 \\
2 & 41714 & 0.774 \\
3 & 40050 & 0.783 \\
4 & 129165 & 0.300 \\
5 & 172125 & 0.068 \\
6 & 181792 & 0.015 \\
7 & 184376 & 0.0012 \\
8 & 184612 & 0.000 \\
\hline
\end{tabular}

Table A.1: A Sample Calculation for LTOC 


\section{Appendix B}

\section{BET AREA MEASUREMENT}

\begin{tabular}{||l|c|c|c|c||}
\hline $\begin{array}{l}\mathrm{C}_{N_{2}} \\
(\%)\end{array}$ & $\mathrm{P} / \mathrm{P}_{0}$ & $\begin{array}{c}\mathrm{A}_{\text {des }} \\
\text { (counts) }\end{array}$ & $\begin{array}{c}\mathrm{A}_{\text {cal }} \\
\text { (counts) }\end{array}$ & $1 /\left(\mathrm{X}\left(\mathrm{P} / \mathrm{P}_{0}-1\right)\right)$ \\
\hline 0.137 & 0.135 & 314 & 336 & 143.7 \\
0.187 & 0.183 & 466 & 452 & 186.8 \\
0.233 & 0.228 & 609 & 566 & 236.2 \\
0.301 & 0.295 & 890 & 718 & 292.0 \\
\hline
\end{tabular}

Table B.1: BET Area Measurement

The BET area was determined by $\mathrm{N}_{2}$ adsorption at $-195^{\circ} \mathrm{C}$ using a Quantasorb analyzer. Nitrogen partial pressure was changed by regulating the flow rate of $\mathrm{N}_{2}$ in a $\mathrm{N}_{2} / \mathrm{He}$ mixture. The incremental volumes adsorbed were detected by the thermal conductivity detector. The corresponding calibration constant was used to convert peak area to adsorbed $\mathrm{N}_{2}$ volume.

\section{Example (BET-15): BET Area Calculation}

Weight of catalyst $=0.0215 \mathrm{~g}$

Calibration (pure $\mathrm{N}_{2}$ ) volume $=1.0 \mathrm{~mL}$

Saturation pressure of $\mathrm{N}_{2}$ at $-195^{\circ} \mathrm{C}=\mathrm{P}_{0}=775 \mathrm{~mm} \mathrm{Hg}$

$\mathrm{N}_{2}$ concentration $=\mathrm{C}_{N_{2}}=\mathrm{V}_{\mathrm{N}_{2}} / \mathrm{V}_{\text {Total }}$

Integration peak area of desorption $=\mathbf{A}_{d c: s}$ 
Integration peak area of calibration $=A_{\text {cal }}$

The BET equation is:

$$
\frac{1}{X\left(\frac{P_{0}}{P}-1\right)}=\frac{C-1}{X_{m} C} \frac{P}{P_{0}}+\frac{1}{X_{m} C}
$$

Here $\mathrm{X}_{m}$ is the volume required for monolayer adsorption and $\mathrm{C}$ is a constant for the surface. A plot of $1 / X\left(P_{0} / P-1\right)$ vs. $P / P_{0}$ gives a straight line in the range $P / P_{0}=0.05-0.35$. The intercept and slope can be used to calculate BET area.

A BET plot corresponding to the data in Table B.1 is shown in Figure B.1. A least square fit was obtained as $\mathrm{Y}=920.3 \mathrm{X}+17.0$. Therefore,

$\mathrm{X}_{m}=1 /($ Slope + Intercept $)=1 /(920.3+17.0)=1.06 \times 10^{-3}$

$\mathrm{S}_{t}=3.483 \times 10^{3} \mathrm{X}_{m}=3.691\left(\mathrm{~m}^{2}\right)$

BET area $=S_{t} /$ Catalyst Weight $=3.691 / 0.0215=171.7\left(\mathrm{~m}^{2} / \mathrm{g}\right)$ 


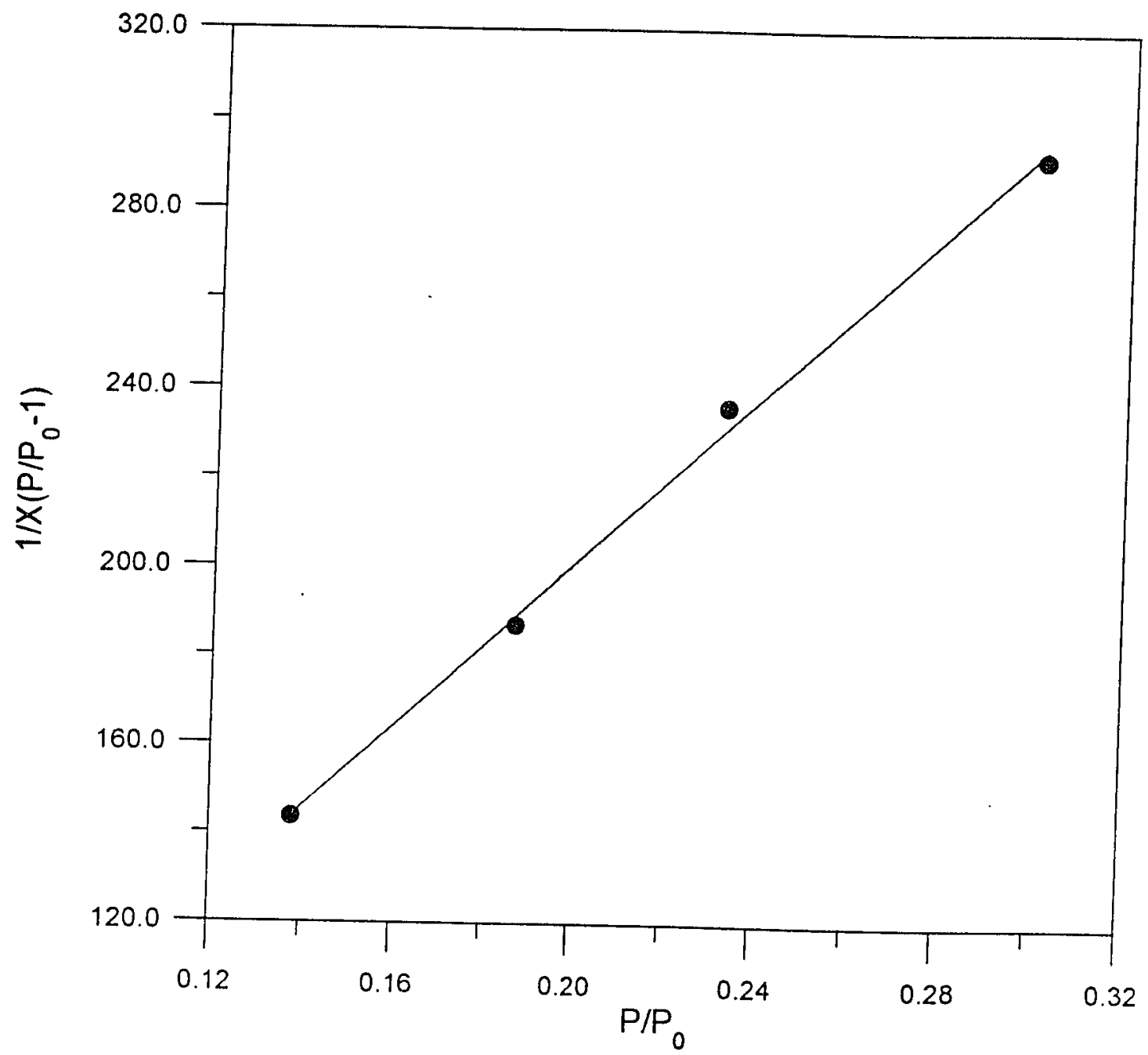

Figure B.1: BET plot for the catalyst prepared by $10^{\circ} \mathrm{C} / \mathrm{min}$ decomposition followed by TPR and TPD. BET area $=171.7\left(\mathrm{~m}^{2} / \mathrm{g}\right)$ 


\section{Appendix C}

\section{HYDROGEN SULFIDE EVOLUTION}

The $\mathrm{H}_{2} \mathrm{~S}$ exiting the reactor during TPR and TPD can be determined by the total area under the signal curve from the thermal conductivity detector. A calibration constant for $\mathrm{H}_{2} \mathrm{~S}$ can be obtained by injection of known volume, known concentration of $\mathrm{H}_{2} \mathrm{~S}$ into the reactor.

Example (Run7-3): $\mathrm{H}_{2} \mathrm{~S}$ evolution during the TPD

Total peak area under detector signal $=2725954$ (count)

Sampling loop volume $=5(\mathrm{~mL})$

$\mathrm{H}_{2} \mathrm{~S}$ concentration in calibration sample $=15.3 \%$

$\mathrm{H}_{2} \mathrm{~S}$ counts for $5 \mathrm{~mL}$ calibration injection $=550403$ (count)

$\mathrm{H}_{2} \mathrm{~S}$ calibration const. $=550403 /(5 \times 15.3 \%)=719481($ count $/ \mathrm{mL})$

Amount of $\mathrm{H}_{2} \mathrm{~S}$ in TPD $=2725954 / 719581=3.79(\mathrm{~mL})$

Weight of catalyst $=0.1998(\mathrm{~g})$

$\mathrm{H}_{2} \mathrm{~S}$ evolution $=3.79 / 0.1998=18.97(\mathrm{~mL} / \mathrm{g})$

Calibration was conducted for each TPD or TPR run since the base line of a gas chromatograph may vary between runs. Considering that the amount of $\mathrm{H}_{2} \mathrm{~S}$ injected for calibration is much less than the $\mathrm{H}_{2} \mathrm{~S}$ effluent from TPD or TPR processes, an experiment was conducted to ensure that a linear correlation existed between $\mathrm{H}_{2} \mathrm{~S}$ volume and integration counts. The calibration curve is shown in Figure C.1. Good linearity of the plot 
ensured the accuracy of calibration. 


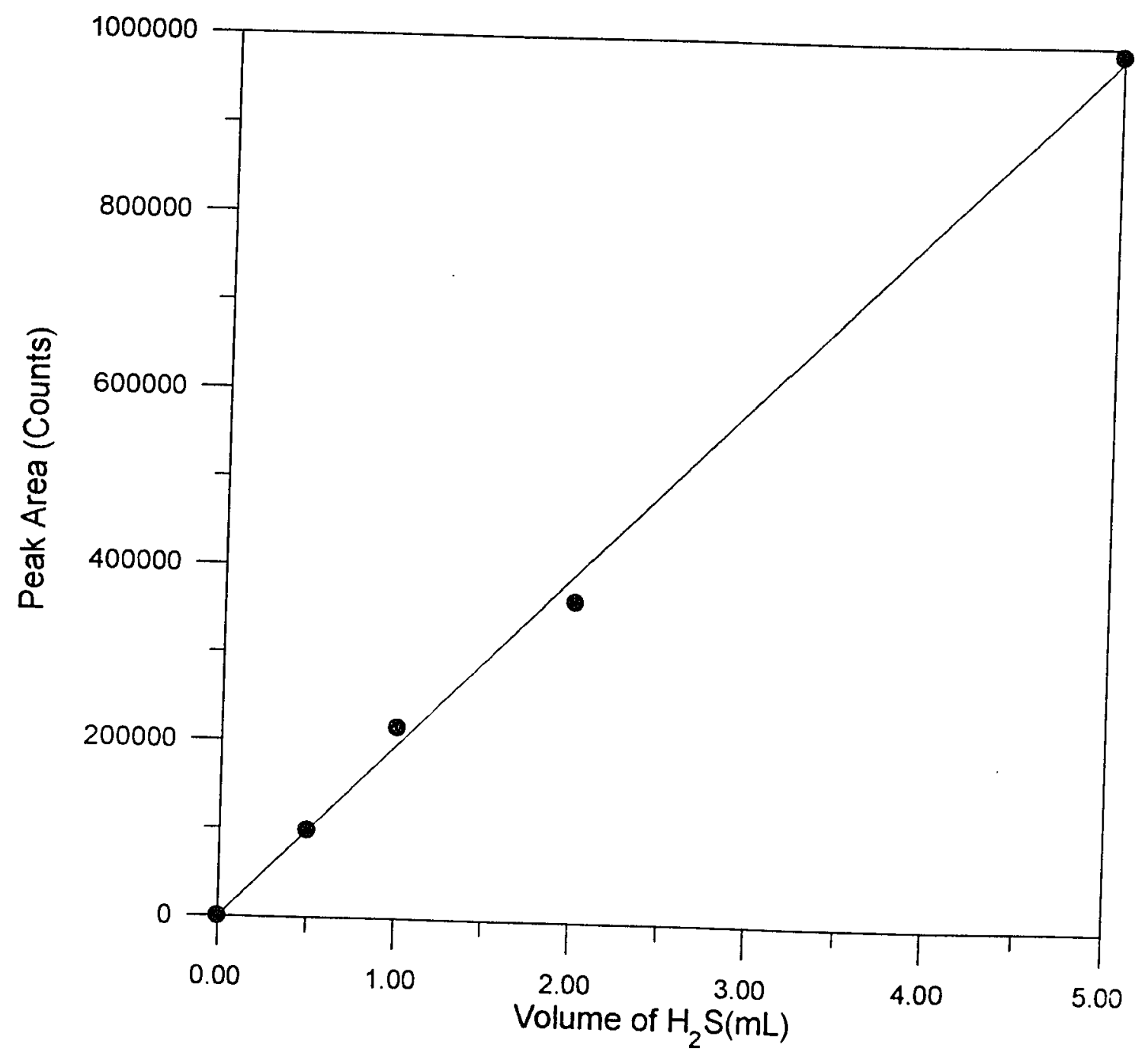

Figure C.1: Integration Constant for $\mathrm{H}_{2} \mathrm{~S}$ Evolution

97 


\section{Appendix D}

\section{PRODUCT COMPOSITION MEASUREMENT}

Typical outputs obtained from a gas chromatograph integrator for the analysis of thiophene HDS and propylene HYD activities are shown in Figure D.1. The product peaks were identified by the retention time of the pure components. The calibration constants for various gases were determined by injecting known volumes of pure components directly into the gas chromatograph.

Two methods were used for the calculation of thiophene conversion. Method I was used for continuous activity measurement. Method II was used for pulse activity measurement.

\section{Method I}

A known volume $(1 \mathrm{~mL})$ of reactant (thiophene $/ \mathrm{H}_{2}$ or propylene $/ \mathrm{H}_{2}$ mixture) was injected into a carrier gas, hydrogen, which flowed through a gas chromatograph at 35 $\mathrm{mL} / \mathrm{min}$. The peak area of integration output indicated the thiophene concentration before reaction. Then, the same amount $(1 \mathrm{~mL})$ of reaction product was injected intogithe same carrier gas and the unconverted thiophene (or propylene) was separated with other components by a Durapak column. The ratio of thiophene (or propylene) counts before and after reaction was used to determine the thiophene conversion.

Example (Run 6-15): Thiophene Conversion (Method I)

Here $\mathrm{T}_{u}$ : Unconverted thiophene. $\mathrm{T}_{0}$ : Thiophene in reactant. 


\begin{tabular}{||l|c|c|c||}
\hline $\begin{array}{l}\text { Time } \\
(\mathrm{hr})\end{array}$ & $\begin{array}{c}\mathrm{T}_{u} \\
\text { (counts) }\end{array}$ & $\begin{array}{c}\mathrm{T}_{0} \\
\text { (counts) }\end{array}$ & $\begin{array}{c}\text { Thiophene Conv. } \\
\left(1-\mathrm{T}_{u} / \mathrm{T}_{0}\right)(\%)\end{array}$ \\
\hline 0 & 86505 & 390931 & 77.8 \\
0.5 & 90458 & 355731 & 74.5 \\
1.0 & 91394 & 320543 & 71.5 \\
2.0 & 101072 & 320543 & 68.4 \\
2.5 & 100305 & 320543 & 68.7 \\
3.0 & 102457 & 320543 & 68.0 \\
3.5 & 96283 & 320543 & 69.9 \\
\hline
\end{tabular}

Table D.1: Thiophene Conversion

\section{Method II}

Thiophene is converted to $\mathrm{H}_{2} \mathrm{~S}$ and $\mathrm{C}_{4}$ components based on the following equation:

$$
2 \mathrm{C}_{4} \mathrm{H}_{4} \mathrm{~S}+7 \mathrm{H}_{2} \longrightarrow 2 \mathrm{H}_{2} \mathrm{~S}+\mathrm{C}_{4} \mathrm{H}_{8}+\mathrm{C}_{4} \mathrm{H}_{10}
$$

A pulse of $2 \mu \mathrm{L}$ (liquid) thiophene was injected from a heated injection port into the carrier gas $\left(\mathrm{H}_{2} 35 \mathrm{~mL} / \mathrm{min}\right)$ which carried thiophene through the catalyst bed into the gas chromatograph. Separation of thiophene, $\mathrm{H}_{2} \mathrm{~S}$, butane and butene was achieved on a Durapak column at $45^{\circ} \mathrm{C}$. Pulses of $\mathrm{H}_{2} \mathrm{~S}(100 \mu \mathrm{L})$ and butane or butene $(200 \mu \mathrm{L})$ were injected into the same carrier gas in order to calibrate the retention time and to gain the calibration constants.

The mole amount of thiophene in the reactant $(2 \mu \mathrm{L})$ is calculated as follows:

$$
\begin{aligned}
& \mathrm{D}_{1}{ }^{20}=1.05 \times 10^{33}(\mathrm{~g} / \mathrm{L}) \\
& \mathrm{W}=2 \mu \mathrm{L} \times \mathrm{D}_{4}{ }^{20}=2.1 \times 10^{-3}(\mathrm{~g}) \\
& \mathrm{Mw}=84.15(\mathrm{~g} / \text { mole }) \\
& \text { Mole }=2.1 \times 10^{-3} / 84.15=2.49 \times 10^{-i} \text { (mole) }
\end{aligned}
$$


The mole amount of butene calibration $(200 \mu \mathrm{L})$ is calculated as follow:

$\mathrm{Mw}=56(\mathrm{~g} / \mathrm{mole}), \mathrm{T}=293(\mathrm{~K}), \mathrm{P}=1$ (atm)

$\rho=\mathrm{P} \mathrm{Mw} / \mathrm{R} \mathrm{T}=(1 \times 56) /(82.06 \times 293)=2.32(\mathrm{~g} / \mathrm{L})$

Mole $=200 \mu \mathrm{L} \times \rho / \mathrm{Mw}=8.286 \times 10^{-6}($ mole $)$

Thiophene conversion (\%) $=C_{4}$ formation (\%)

$\mathrm{C}_{4}$ formation (\%) $=100 \times \mathrm{C}_{4}$ in product (mole)/Thiophene in reactant (mole)

$=100 \times\left(C_{4}\right.$ peak counts $)\left(8.286 \times 10^{-6}\right.$ mole $/$ Butene peak counts $) /\left(2.49 \times 10^{-5}\right.$ mole $)$ 


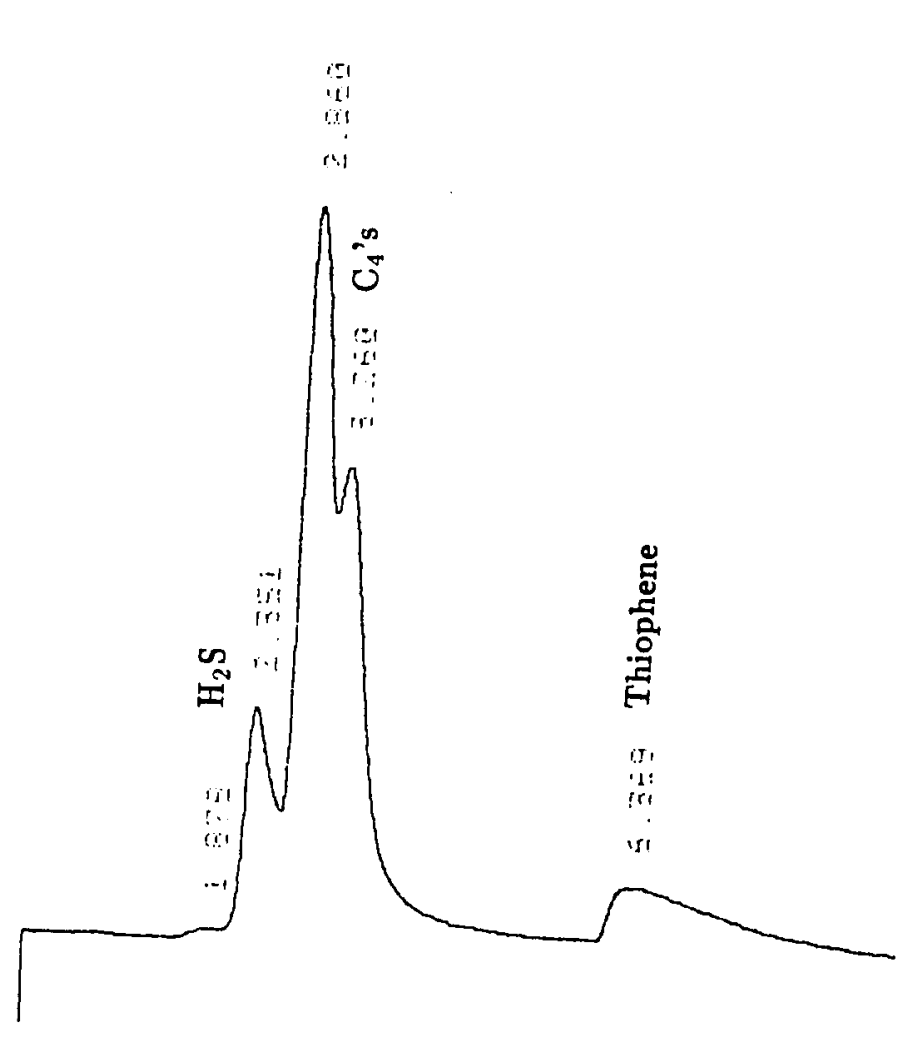

(a)

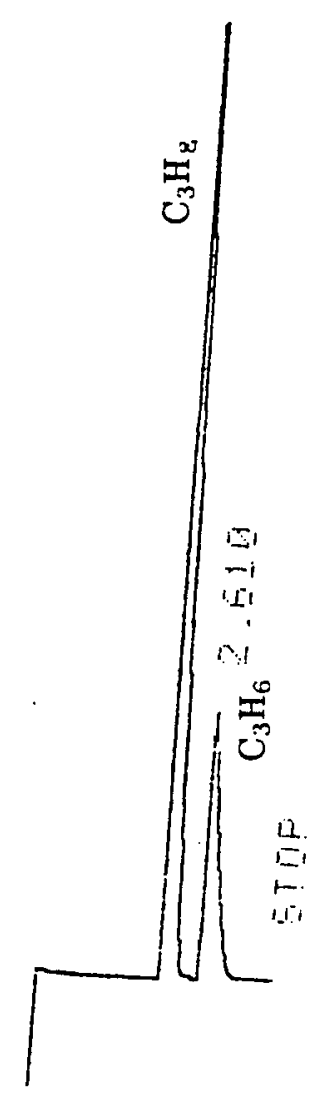

(b)

Figure D.1: Separation of reaction products by GC for thiophene HDS and propylene HYD (a) Thiophene HDS (b) Propylene HYD 


\section{Appendix E}

\section{COBALT LOADING CALCULATION}

Supported Co-promoted catalyst was prepared by introducing $\mathrm{ATTM} / \mathrm{Al}_{2} \mathrm{O}_{3}$ powder into a beaker containing a solution of cobalt nitrate at ambient temperature and under a nitrogen blanket. By knowing the pore volume, the amount of cobalt nitrate for certain Co loading can be calculated.

Example: Make a CoMo/ $\mathrm{Al}_{2} \mathrm{O}_{3}$ catalyst with $3.0 \% \mathrm{CoO}$ Loading.

Pore volume of ATTM $/ \mathrm{Al}_{2} \mathrm{O}_{3} \approx$ pore volume of alumina support $=0.735(\mathrm{~mL} / \mathrm{g})$

Molecular weight of Co: $M w_{1}=59(\mathrm{~g} /$ mole $)$

Molecular weight of $\mathrm{CoO}: \mathrm{Mw}_{2}=75(\mathrm{~g} / \mathrm{mole})$

Molecular weight of $\mathrm{Co}\left(\mathrm{NO}_{3}\right)_{2} \cdot 6 \mathrm{H}_{2} \mathrm{O}: \mathrm{Mw}_{3}=291.0(\mathrm{~g} / \mathrm{mole})$

If $\mathrm{CoO}$ loading $=3.0 \%$

Co loading $=0.03 \times(59 / 75)=0.024(\%)$

Assuming the weight of $\mathrm{Co}\left(\mathrm{NO}_{3}\right)_{2}$ is $\mathrm{W}_{C o}$

$$
\frac{W_{C o} \frac{M / w_{1}}{M / u_{3}}}{W_{C o}+W_{.4}}=0.024
$$

To promote 1 gram of $\mathrm{ATTM} / \mathrm{Al}_{2} \mathrm{O}_{3}$ :

Weight of $\mathrm{Co}\left(\mathrm{NO}_{3}\right)_{2}=\mathrm{W}_{\mathrm{Co}}=0.134(\mathrm{~g})$

Volume of $\mathrm{Co}\left(\mathrm{No}_{3}\right)_{2}$ solution $=0.734 \mathrm{~W}_{4}$ 


\section{Appendix $\mathbf{F}$}

\section{RAW DATA}

- Experiment Series 4: Thiophene Hydrodesulfurization (HDS) Activity, Pulse Method.

- Experiment Series 5: Low Temperature Oxygen Chemisorption (LTOC).

- Experiment Series 6: Thiophene Hydrodesulfurization (HDS) Activity, Continuous Method.

- Experiment Series 7: Temperature-Programmed Desorption (TPD) of Hydrogen Sulfide.

- Experiment Series 8: Propylene Hydrogenation (HYD) Activity.

- Experiment Series 9: Cobalt Promoted Molybdenum Sulfide Catalyst.

- Experiment Series 10: BET Area Measurement. 
Run 4-14 ATTM $/ \mathrm{Al}_{2} \mathrm{O}_{3}$, Thiophene HDS Activity, Pulse

\begin{tabular}{||l|l||}
\hline Date & $7 / 31 / 93$ \\
\hline Catalyst Weight & $0.1997 \mathrm{~g}$ \\
\hline Pretreatment & $10^{\circ} \mathrm{C} /$ min decomposition $+\mathrm{TPR}$ to $550^{\circ} \mathrm{C}$ \\
\hline Thiophene & $2 \mu \mathrm{L}$ thiophene injected in $\mathrm{H}_{2}$ \\
\hline Calibration & $200 \mu \mathrm{L}$ Butane, Counts $=325000$ \\
\hline \hline Average Conversion $(\%)$ & 83.4 \\
\hline
\end{tabular}

\begin{tabular}{||l|c|c||}
\hline Pulse No. & $\mathrm{C}_{4}$ Components (counts) & Conversion (\%) \\
\hline 1 & 826677 & 80.6 \\
2 & 912561 & 89.0 \\
3 & 852382 & 83.1 \\
4 & 921716 & 89.9 \\
5 & 837113 & 81.7 \\
7 & 814762 & 79.5 \\
8 & 907282 & 88.5 \\
9 & 845036 & 82.4 \\
10 & 804962 & 78.5 \\
\hline
\end{tabular}


Run 4-16 ATTM $/ \mathrm{Al}_{2} \mathrm{O}_{3}$, Thiophene HDS Activity, Pulse

\begin{tabular}{||l|l||}
\hline Date & $8 / 4 / 92$ \\
\hline Catalyst Weight & $0.1995 \mathrm{~g}$ \\
\hline Pretreatment & $\mathrm{H}_{2}$ reduction at $15^{\circ} \mathrm{C} / \mathrm{min}$ to $550^{\circ} \mathrm{C}$, \\
\hline Thiophene & $2 \mu \mathrm{L}$ thiophene injected in $\mathrm{H}_{2}$ \\
\hline Calibration & $200 \mu \mathrm{L}$ Butane Counts $=314608$ \\
\hline \hline Average Conversion $(\%)$ & 87.0 \\
\hline
\end{tabular}

\begin{tabular}{||l|c|c||}
\hline Pulse No. & C $_{4}$ 's Components (counts) & Conversion (\%) \\
\hline 1 & 877629 & 88.4 \\
2 & 866168 & 87.3 \\
4 & 898243 & 90.5 \\
5 & 891664 & 89.4 \\
6 & 787087 & 79.3 \\
7 & 863573 & 87.0 \\
8 & 857399 & 86.4 \\
9 & 906518 & 91.3 \\
10 & 820168 & 82.7 \\
\hline
\end{tabular}


Run 4-20 Harshaw 0402T, Thiophene HDS Activity, Pulse

\begin{tabular}{||l|l||}
\hline Date & $8 / 11 / 92$ \\
\hline Catalyst Weight & $0.1997 \mathrm{~g}$ \\
\hline Pretreatment & Redutive Sulfiding $+\mathrm{TPR}$ \\
\hline Thiophene & $2 \mu \mathrm{l}$ thiophene injected in $\mathrm{H}_{2}$ \\
\hline Calibration & $200 \mu \mathrm{l}$ Butane , Counts $=301709$ \\
\hline \hline Average Conversion $(\%)$ & 67.7 \\
\hline
\end{tabular}

\begin{tabular}{||l|c|c||}
\hline Pulse No. & C $_{4}$ 's Component (counts) & Conversion (\%) \\
\hline 1 & 631995 & 66.4 \\
3 & 619154 & 65.1 \\
4 & 634105 & 66.6 \\
5 & 637244 & 67.0 \\
6 & 678940 & 71.3 \\
7 & 579591 & 60.9 \\
8 & 681597 & 71.6 \\
9 & 679073 & 71.3 \\
\hline
\end{tabular}


Run 4-22 Harshaw 0402T, Thiophene HDS Activity, Pulse

\begin{tabular}{||l|l||}
\hline Date & $8 / 13 / 92$ \\
\hline Catalyst Weight & $0.2006 \mathrm{~g}$ \\
\hline Pretreatment & Redutive Sulfiding + TPR \\
\hline Thiophene & $2 \mu \mathrm{l}$ thiophene injected in $\mathrm{H}_{2}$ \\
\hline Calibration & $200 \mu \mathrm{l}$ Butane, Counts $=307508$ \\
\hline \hline Average Conversion $(\%)$ & 84.4 \\
\hline
\end{tabular}

\begin{tabular}{||l|c|c||}
\hline Pulse No. & C $_{4}$ 's Component (counts) & Conversion (\%) \\
\hline 1 & 894351 & 92.2 \\
3 & 866735 & 89.3 \\
4 & 837405 & 86.3 \\
5 & 805088 & 83.0 \\
6 & 798392 & 82.3 \\
7 & 798209 & 82.3 \\
8 & 815161 & 84.0 \\
9 & 807465 & 83.2 \\
10 & 789411 & 81.4 \\
\hline
\end{tabular}


Run 4-24 $\mathrm{MoO}_{3} / \mathrm{Al}_{2} \mathrm{O}_{3}$, Thiophene HDS Activity, Pulse

\begin{tabular}{||l|l||}
\hline Date & $8 / 15 / 92$ \\
\hline Catalyst Weight & $0.2003 \mathrm{~g}$ \\
\hline Pretreatment & Redutive Sulfiding $+\mathrm{TPR}$ \\
\hline Thiophene & $2 \mu \mathrm{l}$ thiophene injected in $\mathrm{H}_{2}$ \\
\hline Calibration & $200 \mu \mathrm{l}$ Butane, Counts $=323993$ \\
\hline \hline Average Conversion (\%) & 57.5 \\
\hline
\end{tabular}

\begin{tabular}{||l|c|c||}
\hline Pulse No. & C $_{4}$ 's Component (counts) & Conversion (\%) \\
\hline 1 & 632043 & 61.8 \\
3 & 575617 & 56.3 \\
4 & 609928 & 59.7 \\
5 & 594079 & 58.1 \\
6 & 600622 & 58.8 \\
7 & 572065 & 56.0 \\
8 & 599302 & 58.6 \\
9 & 550547 & 53.9 \\
10 & 581851 & 56.9 \\
\hline
\end{tabular}


Run 4-27 ATTM $/ \mathrm{Al}_{2} \mathrm{O}_{3}$, Thiophene HDS Activity, Pulse

\begin{tabular}{||l|l||}
\hline Date & $9 / 13 / 93$ \\
\hline Catalyst Weight & $0.2000 \mathrm{~g}$ \\
\hline Pretreatment & Flash decomposition + TPR \\
\hline Thiophene & $2 \mu 1$ thiophene injected in $\mathrm{H}_{2}$ \\
\hline Calibration & $200 \mu \mathrm{l}$ Butane, Counts $=314535$ \\
\hline \hline Average Conversion $(\%)$ & 80.5 \\
\hline
\end{tabular}

\begin{tabular}{||l|c|c||}
\hline Pulse No. & C $_{4}$ 's Component (counts) & Conversion (\%) \\
\hline 1 & 774724 & 78.1 \\
2 & 792964 & 79.9 \\
3 & 781933 & 78.8 \\
5 & 835077 & 84.2 \\
6 & 815872 & 82.2 \\
7 & 824802 & 83.1 \\
8 & 819952 & 82.6 \\
9 & 707159 & 71.3 \\
\hline
\end{tabular}


Run 4-28 ATTM $/ \mathrm{Al}_{2} \mathrm{O}_{3}$, Thiophene HDS Activity, Pulse

\begin{tabular}{||l|l||}
\hline Date & $10 / 1 / 93$ \\
\hline Catalyst Weight & $0.1992 \mathrm{~g}$ \\
\hline Pretreatment & $10^{\circ} \mathrm{C} /$ min decomposition $+\mathrm{TPR}$ to $420^{\circ} \mathrm{C}$ \\
\hline Thiophene & $2 \mu \mathrm{l}$ thiophene injected in $\mathrm{H}_{2}$ \\
\hline Calibration & $200 \mu \mathrm{l}$ Butane, Counts $=316239$ \\
\hline \hline Average Conversion $(\%)$ & 72.3 \\
\hline
\end{tabular}

\begin{tabular}{||l|c|c||}
\hline Pulse No. & C $_{4}$ 's Component (counts) & Conversion (\%) \\
\hline 1 & 766715 & 76.9 \\
3 & 711005 & 71.3 \\
4 & 764543 & 76.6 \\
5 & 725377 & 72.7 \\
6 & 750257 & 75.2 \\
7 & 730193 & 73.2 \\
8 & 675227 & 67.7 \\
9 & 747523 & 74.9 \\
10 & 659198 & 66.1 \\
\hline
\end{tabular}




\begin{tabular}{||l|l||}
\hline Date & $10 / 5 / 92$ \\
\hline Catalyst Weight & $0.1990 \mathrm{~g}$ \\
\hline Pretreatment & Flash decomposition + TPR to $550^{\circ} \mathrm{C}$ \\
\hline Sampling Loop & $1 \mathrm{~mL}$ \\
\hline GC Setting & $\begin{array}{l}\mathrm{T}_{\text {oven }}=70^{\circ} \mathrm{C}, \mathrm{T}_{T C D}=100^{\circ} \mathrm{C} \\
\mathrm{He}=35 \mathrm{~mL} / \mathrm{min}\end{array}$ \\
\hline \hline LTOC & $1.21(\mathrm{~mL} / \mathrm{g})$ \\
\hline
\end{tabular}

\begin{tabular}{||c|c|c||}
\hline Pulse No. & Peak Area (counts) & $\Delta_{i}$ \\
\hline $1-14$ & 0 & 1 \\
15 & 3163 & 0.872 \\
16 & 6750 & 0.727 \\
17 & 18416 & 0.255 \\
18 & 23848 & 0.035 \\
19 & 23096 & 0.066 \\
20 & 23710 & 0.041 \\
21 & 24704 & 0.000 \\
\hline
\end{tabular}


Run 5-2 ATTM/ $/ \mathrm{Al}_{2} \mathrm{O}_{3}$, Low Ternperature Oxygen Chemisorption

\begin{tabular}{||l|l||}
\hline Date & $10 / 13 / 92$ \\
\hline Catalyst Weight & $0.2007 \mathrm{~g}$ \\
\hline Pretreatment & $10^{\circ} \mathrm{C} / \mathrm{min}$ decomposition $+\mathrm{TPR}$ to $550^{\circ} \mathrm{C}$ \\
\hline Sampling Loop & $1 \mathrm{~mL}$ \\
\hline GC Setting & $\begin{array}{l}\mathrm{T}_{\text {oven }}=70^{\circ} \mathrm{C}, \mathrm{T}_{T C D}=100^{\circ} \mathrm{C} \\
\mathrm{He}=35 \mathrm{~mL} / \mathrm{min}\end{array}$ \\
\hline \hline LTOC & $1: 42(\mathrm{~mL} / \mathrm{g})$ \\
\hline
\end{tabular}

\begin{tabular}{||c|c|c||}
\hline Pulse No. & Peak Area (counts) & $\Delta_{i}$ \\
\hline $1-17$ & 0 & 1 \\
18 & 2543 & 0.873 \\
19 & 6719 & 0.664 \\
20 & 16007 & 0.199 \\
21 & 18535 & 0.073 \\
22 & 19352 & 0.032 \\
23 & 18097 & 0.095 \\
24 & 19604 & 0.019 \\
25 & 19988 & 0.000 \\
\hline
\end{tabular}


$\underline{\text { Run 5-4 ATTM } / \mathrm{Al}_{2} \mathrm{O}_{3} \text {, Low Temperature Oxygen Chemisorption }}$

\begin{tabular}{||l|l||}
\hline Date & $12 / 7 / 92$ \\
\hline Catalyst Weight & $0.2004 \mathrm{~g}$ \\
\hline Pretreatment & Flash decomposition + TPR to $550^{\circ} \mathrm{C}$ \\
\hline Sampling Loop & $1 \mathrm{~mL}$ \\
\hline GC Setting & $\begin{array}{l}\mathrm{T}_{\text {oven }}=70^{\circ} \mathrm{C}, \mathrm{T}_{T C D}=100^{\circ} \mathrm{C} \\
\mathrm{He}=35 \mathrm{~mL} / \mathrm{min}\end{array}$ \\
\hline \hline LTOC & $1.61(\mathrm{~mL} / \mathrm{g})$ \\
\hline
\end{tabular}

\begin{tabular}{||c|c|c||}
\hline Pulse No. & Peak Area (counts) & $\Delta_{i}$ \\
\hline $1-19$ & 0 & 1 \\
20 & 3659 & 0.805 \\
21 & 3588 & 0.809 \\
22 & 11234 & 0.402 \\
23 & 16677 & 0.112 \\
24 & 17458 & 0.070 \\
25 & 17925 & 0.045 \\
26 & 18094 & 0.036 \\
27 & 18355 & 0.022 \\
28 & 18777 & 0.000 \\
29 & 18608 & 0.009 \\
\hline
\end{tabular}




\begin{tabular}{||l|l||}
\hline Date & $1 / 15 / 93$ \\
\hline Catalyst Weight & $0.1994 \mathrm{~g}$ \\
\hline Pretreatment & $\mathrm{H}_{2}$ reduction at $15^{\circ} \mathrm{C} / \mathrm{min}$ to $550^{\circ} \mathrm{C}$ \\
\hline Sampling Loop & $5 \mathrm{~mL}$ \\
\hline GC Setting & $\begin{array}{l}\mathrm{T}_{\text {oven }}=70^{\circ} \mathrm{C}, \mathrm{T}_{T C D}=100^{\circ} \mathrm{C} \\
\mathrm{He}=35 \mathrm{~mL} / \mathrm{min}\end{array}$ \\
\hline \hline LTOC & $0.894(\mathrm{~mL} / \mathrm{g})$ \\
\hline
\end{tabular}

\begin{tabular}{||c|c|c||}
\hline Pulse No. & Peak Area (counts) & $\Delta_{i}$ \\
\hline 1 & 3221 & 0.975 \\
2 & 38791 & 0.694 \\
3 & 71245 & 0.437 \\
4 & 95697 & 0.244 \\
5 & 124847 & 0.014 \\
6 & 126541 & 0.0002 \\
7 & 126563 & 0.000 \\
\hline
\end{tabular}


Run 5-11 Harshaw 0402T, Low Temperature Oxygen Chemisorption

\begin{tabular}{||l|l||}
\hline Date & $1 / 23 / 93$ \\
\hline Catalyst Weight & $0.1993 \mathrm{~g}$ \\
\hline Pretreatment & Reductive Sulfiding $+\mathrm{TPR}$ \\
\hline Sampling Loop & $5 \mathrm{~mL}$ \\
\hline GC Setting & $\begin{array}{l}\mathrm{T}_{\text {oven }}=70^{\circ} \mathrm{C}, \mathrm{T}_{T C D}=100^{\circ} \mathrm{C} \\
\mathrm{He}=35 \mathrm{~mL} / \mathrm{min}\end{array}$ \\
\hline \hline LTOC & $0.19(\mathrm{~mL} / \mathrm{g})$ \\
\hline
\end{tabular}

\begin{tabular}{||c|c|c||}
\hline Pulse No. & Peak Area (counts) & $\Delta_{i}$ \\
\hline 1 & 134506 & 0.174 \\
2 & 162844 & 0.000 \\
3 & 147139 & 0.096 \\
4 & 144449 & 0.113 \\
5 & 144273 & 0.114 \\
\hline
\end{tabular}

115 
$\underline{\text { Run 5-24 } \mathrm{MoO}_{3} / \mathrm{Al}_{2} \mathrm{O}_{3} \text {, Low Temperature Oxygen Chemisorption }}$

\begin{tabular}{||l|l||}
\hline Date & $4 / 6 / 93$ \\
\hline Catalyst Weight & $0.1994 \mathrm{~g}$ \\
\hline Pretreatment & Resuctive Sulfiding $+\mathrm{TPR}$ to $550^{\circ} \mathrm{C}$ \\
\hline Sampling Loop & $5 \mathrm{~mL}$ \\
\hline GC Setting & $\begin{array}{l}\mathrm{T}_{\text {oven }}=70^{\circ} \mathrm{C}, \mathrm{T}_{T C D}=100^{\circ} \mathrm{C} \\
\mathrm{He}=35 \mathrm{~mL} / \mathrm{min}\end{array}$ \\
\hline \hline LTOC & $0.56(\mathrm{~mL} / \mathrm{g})$ \\
\hline
\end{tabular}

\begin{tabular}{|c|c|c||}
\hline Pulse No. & Peak Area (counts) & $\Delta_{i}$ \\
\hline 1 & 12821 & 0.909 \\
2 & 84837 & 0.948 \\
3 & 151687 & 0.044 \\
4 & 153326 & 0.034 \\
5 & 156794 & 0.012 \\
6 & 158103 & 0.004 \\
7 & 156945 & 0.011 \\
8 & 158690 & 0.000 \\
\hline
\end{tabular}




\begin{tabular}{||l|l||}
\hline Date & $5 / 26 / 93$ \\
\hline Catalyst Weight & $0.2005 \mathrm{~g}$ \\
\hline Pretreatment & Flash decomposition + TPR to $550^{\circ} \mathrm{C}$ \\
\hline Sampling Loop & $5 \mathrm{~mL}$ \\
\hline GC Setting & $\begin{array}{l}\mathrm{T}_{\text {oven }}=70^{\circ} \mathrm{C}, \mathrm{T}_{T C D}=100^{\circ} \mathrm{C} \\
\mathrm{He}=35 \mathrm{~mL} / \mathrm{min}\end{array}$ \\
\hline \hline LTOC & $1.02(\mathrm{~mL} / \mathrm{g})$ \\
\hline
\end{tabular}

\begin{tabular}{||c|c|c||}
\hline Pulse No. & Peak Area (counts) & $\Delta_{i}$ \\
\hline 1 & 44581 & 0.759 \\
2 & 41714 & 0.774 \\
3 & 40050 & 0.783 \\
4 & 129165 & 0.300 \\
5 & 172125 & 0.068 \\
6 & 181792 & 0.015 \\
7 & 184376 & 0.001 \\
8 & 184612 & 0.000 \\
\hline
\end{tabular}

117 
Run 5-39 ATTM $/ \mathrm{Al}_{2} \mathrm{O}_{3}$, Low Temperature Oxygen Chemisorption

\begin{tabular}{||l|l||}
\hline Date & $5 / 27 / 93$ \\
\hline Catalyst Weight & $0.2001 \mathrm{~g}$ \\
\hline Pretreatment & $10^{\circ} \mathrm{C} / \mathrm{min}$ decomposition $+\mathrm{TPR}$ to $550^{\circ} \mathrm{C}$ \\
\hline Sampling Loop & $5 \mathrm{~mL}$ \\
\hline \hline LTOC & $1.46(\mathrm{~mL} / \mathrm{g})$ \\
\hline
\end{tabular}

\begin{tabular}{||c|c|c||}
\hline Pulse No. & Peak Area (counts) & $\Delta_{i}$ \\
\hline 1 & 34068 & 0.821 \\
2 & 26967 & 0.858 \\
3 & 38250 & 0.799 \\
4 & 32865 & 0.827 \\
5 & 143220 & 0.248 \\
6 & 168471 & 0.116 \\
7 & 179624 & 0.058 \\
8 & 181385 & 0.048 \\
9 & 184375 & 0.032 \\
10 & 181960 & 0.045 \\
11 & 183068 & 0.039 \\
12 & 188318 & 0.012 \\
13 & 190646 & 0.000 \\
\hline
\end{tabular}

118 


\begin{tabular}{||l|l||}
\hline Date & $6 / 2 / 93$ \\
\hline Catalyst Weight & $0.2000 \mathrm{~g}$ \\
\hline Pretreatment & $\mathrm{H}_{2}$ reduction at $15^{\circ} \mathrm{C} / \mathrm{min}$ to $550^{\circ} \mathrm{C}$ \\
\hline Sampling Loop & $5 \mathrm{~mL}$ \\
\hline GC Setting & $\begin{array}{l}\mathrm{T}_{\text {oven }}=70^{\circ} \mathrm{C}, \mathrm{T}_{T C D}=100^{\circ} \mathrm{C} \\
\mathrm{He}=35 \mathrm{~mL} / \mathrm{min}\end{array}$ \\
\hline \hline LTOC & $0.75(\mathrm{~mL} / \mathrm{g})$ \\
\hline
\end{tabular}

\begin{tabular}{||c|c|c||}
\hline Pulse No. & Peak Area (counts) & $\Delta_{i}$ \\
\hline 1 & 27028 & 0.851 \\
2 & 44575 & 0.755 \\
3 & 159597 & 0.119 \\
4 & 167919 & 0.073 \\
5 & 171173 & 0.055 \\
6 & 174324 & 0.038 \\
7 & 176201 & 0.028 \\
8 & 175444 & 0.032 \\
9 & 177920 & 0.016 \\
10 & 178349 & 0.0072 \\
11 & 181189 & 0.000 \\
\hline
\end{tabular}


Run 5-43 ATTM $/ \mathrm{Al}_{2} \mathrm{O}_{3}$, Low Temperature Oxygen Chemisorption

\begin{tabular}{||l|l||}
\hline Date & $6 / 3 / 93$ \\
\hline Catalyst Weight & $0.1990 \mathrm{~g}$ \\
\hline Pretreatment & $10^{\circ} \mathrm{C} / \mathrm{min}$ decomposition $+\mathrm{TPR}$ to $420^{\circ} \mathrm{C}$ \\
\hline Sampling Loop & $5 \mathrm{~mL}$ \\
\hline GC Setting & $\begin{array}{l}\mathrm{T}_{\text {oven }}=70^{\circ} \mathrm{C}, \mathrm{T}_{T C D}=100^{\circ} \mathrm{C} \\
\mathrm{He}=35 \mathrm{~mL} / \mathrm{min}\end{array}$ \\
\hline \hline LTOC & $0.57(\mathrm{~mL} / \mathrm{g})$ \\
\hline
\end{tabular}

\begin{tabular}{||c|c|c||}
\hline Pulse No. & Peak Area (counts) & $\Delta_{i}$ \\
\hline 1 & 27604 & 0.837 \\
2 & 99257 & 0.412 \\
3 & 151623 & 0.102 \\
4 & 158257 & 0.063 \\
5 & 159198 & 0.057 \\
6 & 166526 & 0.014 \\
7 & 163678 & 0.031 \\
8 & 168896 & 0.000 \\
\hline
\end{tabular}


Run 5-44 ATTM/ $/ \mathrm{Al}_{2} \mathrm{O}_{3}$, Low Temperature Oxygen Chemisorption

\begin{tabular}{||l|l||}
\hline Date & $6 / 3 / 93$ \\
\hline Catalyst Weight & $0.2004 \mathrm{~g}$ \\
\hline Pretreatment & $\mathrm{H}_{2}$ reduction at $15^{\circ} \mathrm{C} / \mathrm{min}$ to $550^{\circ} \mathrm{C}$ \\
\hline Sampling Loop & $5 \mathrm{~mL}$ \\
\hline GC Setting & $\begin{array}{l}\mathrm{T}_{\text {oven }}=70^{\circ} \mathrm{C}, \mathrm{T}_{T C D}=100^{\circ} \mathrm{C} \\
\mathrm{He}=35 \mathrm{~mL} / \mathrm{min}\end{array}$ \\
\hline \hline LTOC & $0.76(\mathrm{~mL} / \mathrm{g})$ \\
\hline
\end{tabular}

\begin{tabular}{|c|c|c||}
\hline Pulse No. & Peak Area (counts) & $\Delta_{i}$ \\
\hline 1 & 45268 & 0.701 \\
2 & 42121 & 0.721 \\
3 & 86481 & 0.428 \\
4 & 137816 & 0.088 \\
5 & 146549 & 0.030 \\
6 & 148098 & 0.020 \\
7 & 149105 & 0.013 \\
8 & 151125 & 0.000 \\
9 & 150792 & 0.002 \\
\hline
\end{tabular}




\begin{tabular}{||l|l||}
\hline Date & $11 / 28 / 93$ \\
\hline Catalyst Weight & $0.2001 \mathrm{~g}$ \\
\hline Pretreatment & $\mathrm{H}_{2}$ reduction at $15^{\circ} \mathrm{C} / \mathrm{min}$ to $550^{\circ} \mathrm{C}$, \\
\hline Calibration & $5 \mathrm{~mL}$ thiophene $/ \mathrm{H}_{2}$ \\
\hline \hline Average Conversion $(\%)$ & 59.8 \\
\hline
\end{tabular}

\begin{tabular}{||c|c|c|c||}
\hline $\begin{array}{c}\text { Time } \\
(\mathrm{hr})\end{array}$ & $\begin{array}{c}\text { Unconverted Thiophene } \\
\text { (counts) }\end{array}$ & $\begin{array}{c}\text { Calibration } \\
\text { (counts) }\end{array}$ & $\begin{array}{c}\text { Conversion } \\
(\%)\end{array}$ \\
\hline 0.5 & 149048 & 426050 & 65.0 \\
1.0 & 151354 & 426050 & 64.4 \\
2.0 & 179891 & 426050 & 57.7 \\
2.5 & 188817 & 426050 & 55.6 \\
3.0 & 180561 & 426050 & 57.5 \\
3.5 & 172272 & 426050 & 59.5 \\
\hline
\end{tabular}


Run 6-13 ATTM/ $\mathrm{Al}_{2} \mathrm{O}_{3}$, Thiophene HDS Activity, Continuous

\begin{tabular}{||l|l||}
\hline Date & $12 / 10 / 93$ \\
\hline Catalyst Weight & $0.2004 \mathrm{~g}$ \\
\hline Pretreatment & $\begin{array}{l}10^{\circ} \mathrm{C} / \mathrm{min} \text { in } \mathrm{He}, \mathrm{He}=20 \mathrm{cc} / \mathrm{min} \\
+\mathrm{TPR} \text { to } 420^{\circ} \mathrm{C}, \mathrm{H}_{2}=35 \mathrm{cc} / \mathrm{min}\end{array}$ \\
\hline Calibration & $5 \mathrm{~mL}$ thiophene $/ \mathrm{H}_{2}$ \\
\hline Average Conversion $(\%)$ & 56.0 \\
\hline
\end{tabular}

\begin{tabular}{||l|c|c|c||}
\hline $\begin{array}{l}\text { Time } \\
(\mathrm{hr})\end{array}$ & $\begin{array}{c}\text { Unconverted Thiophene } \\
\text { (counts) }\end{array}$ & $\begin{array}{c}\text { Calibration } \\
\text { (counts) }\end{array}$ & $\begin{array}{c}\text { Conversion } \\
(\%)\end{array}$ \\
\hline 0.167 & 155997 & 421074 & 62.9 \\
0.5 & 154020 & 382598 & 59.7 \\
1.5 & 156164 & 344122 & 56.4 \\
2.0 & 158389 & 344122 & 53.9 \\
2.5 & 157753 & 344122 & 54.2 \\
3.0 & 159640 & 344122 & 53.6 \\
\hline
\end{tabular}


Run 6-15 ATTM $/ \mathrm{Al}_{2} \mathrm{O}_{3}$, Thiophene HDS Activity, Continuous

\begin{tabular}{||l|l||}
\hline Date & $12 / 15 / 93$ \\
\hline Catalyst Weight & $0.1998 \mathrm{~g}$ \\
\hline Pretreatment & $\mathrm{H}_{2}$ reduction at $15^{\circ} \mathrm{C} / \mathrm{min}$ to $550^{\circ} \mathrm{C}$, \\
\hline Calibration & $5 \mathrm{~mL}$ thiophene $/ \mathrm{H}_{2}$ \\
\hline \hline Average Conversion $(\%)$ & 71.3 \\
\hline
\end{tabular}

\begin{tabular}{||l|c|c|c||}
\hline $\begin{array}{c}\text { Time } \\
(\mathrm{hr})\end{array}$ & $\begin{array}{c}\text { Unconverted Thiophene } \\
\text { (counts) }\end{array}$ & $\begin{array}{c}\text { Calibration } \\
\text { (counts) }\end{array}$ & $\begin{array}{c}\text { Conversion } \\
(\%)\end{array}$ \\
\hline 0.25 & 86505 & 390931 & 77.8 \\
0.5 & 90458 & 355731 & 74.5 \\
1.0 & 91394 & 320543 & 71.5 \\
2.0 & 101072 & 320543 & 68.4 \\
2.5 & 100305 & 320543 & 68.7 \\
3.0 & 102457 & 320543 & 68.0 \\
3.5 & 96283 & 320543 & 69.9 \\
\hline
\end{tabular}




\begin{tabular}{||l|l||}
\hline Date & $12 / 17 / 93$ \\
\hline Catalyst Weight & $0.2000 \mathrm{~g}$ \\
\hline Pretreatment & Flash in $\mathrm{He}+\mathrm{TPR}$ \\
\hline Calibration & $5 \mathrm{~mL}$ thiophene $/ \mathrm{H}_{2}$ \\
\hline \hline Average Conversion (\%) & 68.0 \\
\hline
\end{tabular}

\begin{tabular}{||l|c|c|c||}
\hline $\begin{array}{c}\text { Time } \\
(\mathrm{hr})\end{array}$ & $\begin{array}{c}\text { Unconverted Thiophene } \\
\text { (counts) }\end{array}$ & $\begin{array}{c}\text { Calibration } \\
\text { (counts) }\end{array}$ & $\begin{array}{c}\text { Conversion } \\
(\%)\end{array}$ \\
\hline 0.167 & 105669 & 389368 & 72.8 \\
1.0 & 113672 & 389868 & 70.8 \\
1.5 & 98783 & 316844.5 & 68.8 \\
2.0 & 111293 & 316844.5 & 64.8 \\
2.5 & 123515 & 316844.5 & 67.2 \\
3.0 & 135739 & 316844.5 & 64.1 \\
3.5 & 122581 & 316844.5 & 67.5 \\
\hline
\end{tabular}


Run 6-17 $\mathrm{MoO}_{3} / \mathrm{Al}_{2} \mathrm{O}_{3}$, Thiophene HDS Activity, Continuous

\begin{tabular}{||l|l||}
\hline Date & $12 / 19 / 93$ \\
\hline Catalyst Weight & $0.1990 \mathrm{~g}$ \\
\hline Pretreatment & Reductive sulfiding $+\mathrm{TPR}$ \\
\hline Calibration & $5 \mathrm{~mL}$ thiophene $/ \mathrm{H}_{2}$ \\
\hline \hline Average Conversion $(\%)$ & 55.0 \\
\hline
\end{tabular}

\begin{tabular}{||l|c|c|c||}
\hline $\begin{array}{c}\text { Time } \\
(\mathrm{hr})\end{array}$ & $\begin{array}{c}\text { Unconverted Thiophene } \\
\text { (counts) }\end{array}$ & $\begin{array}{c}\text { Calibration } \\
\text { (counts) }\end{array}$ & $\begin{array}{c}\text { Conversion } \\
(\%)\end{array}$ \\
\hline 0.167 & 133144 & 329713 & 59.6 \\
0.5 & 126901 & 317065 & 59.9 \\
1.5 & 148349 & 317065 & 53.2 \\
2.0 & 150854 & 317065 & 52.4 \\
2.5 & 142531 & 317065 & 55.0 \\
3.0 & 148077 & 317065 & 53.2 \\
3.5 & 149223 & 317065 & 52.9 \\
\hline
\end{tabular}




\begin{tabular}{||l|l||}
\hline Date & $12 / 20 / 93$ \\
\hline Catalyst Weight & $0.2004 \mathrm{~g}$ \\
\hline Pretreatment & $\begin{array}{l}10^{\circ} \mathrm{C} / \mathrm{min} \text { in } \mathrm{He}, \mathrm{He}=20 \mathrm{cc} / \mathrm{min} \\
+\mathrm{TPR} \text { to } 550^{\circ} \mathrm{C}, \mathrm{H}_{2}=35 \mathrm{cc} / \mathrm{min}\end{array}$ \\
\hline Reaction Temperature & $400^{\circ} \mathrm{C}$ \\
\hline Calibration & $5 \mathrm{~mL}$ thiophene $/ \mathrm{H}_{2}$ \\
\hline \hline Average Conversion (\%) & 70.4 \\
\hline
\end{tabular}

\begin{tabular}{||l|c|c|c||}
\hline $\begin{array}{c}\text { Time } \\
(\mathrm{hr})\end{array}$ & $\begin{array}{c}\text { Unconverted Thiophene } \\
\text { (counts) }\end{array}$ & $\begin{array}{c}\text { Calibration } \\
\text { (counts) }\end{array}$ & $\begin{array}{c}\text { Conversion } \\
(\%)\end{array}$ \\
\hline 0.167 & 94766 & 343023 & 72.3 \\
0.5 & 93239 & 339062 & 72.5 \\
1.0 & 98336 & 339062 & 70.9 \\
1.5 & 100403 & 339062 & 70.4 \\
2.0 & 101878 & 339062 & 69.9 \\
2.5 & 104986 & 339062 & 69.0 \\
3.0 & 109115 & 339062 & 67.8 \\
\hline
\end{tabular}




\begin{tabular}{||l|l||}
\hline Date & $12 / 22 / 93$ \\
\hline Catalyst Weight & $0.2006 \mathrm{~g}$ \\
\hline Pretreatment & Reductive sulfiding $+\mathrm{TPR}$ \\
\hline Calibration & $5 \mathrm{~mL}$ thiophene $/ \mathrm{H}_{2}$ \\
\hline \hline Average Conversion $(\%)$ & 63.5 \\
\hline
\end{tabular}

\begin{tabular}{||l|c|c|c||}
\hline $\begin{array}{l}\text { Time } \\
(\mathrm{hr})\end{array}$ & $\begin{array}{c}\text { Unconverted Thiophene } \\
\text { (counts) }\end{array}$ & $\begin{array}{c}\text { Calibration } \\
\text { (counts) }\end{array}$ & $\begin{array}{c}\text { Conversion } \\
(\%)\end{array}$ \\
\hline 0.167 & 86009 & 437297 & 80.3 \\
0.5 & 121598 & 437297 & 72.2 \\
1.0 & 145673 & 430204 & 66.1 \\
1.5 & 181349 & 430204 & 57.8 \\
2.5 & 179231 & 430204 & 58.3 \\
3.0 & 194270 & 430204 & 54.8 \\
3.5 & 192972 & 430204 & 55.1 \\
3.5 & 149223 & 317065 & 52.9 \\
\hline
\end{tabular}




\begin{tabular}{||l|l||}
\hline Date & $8 / 30 / 94$ \\
\hline Catalyst Weight & $0.1989 \mathrm{~g}$ \\
\hline Pretreatment & Flash decomposition $+\mathrm{TPR}$ to $550^{\circ} \mathrm{C}+\mathrm{TPD}$ to $550^{\circ} \mathrm{C}$ \\
\hline Starting Temperature of TPD & $\mathrm{T}_{0}=23^{\circ} \mathrm{C}$ \\
\hline Calibration & $5 \mathrm{~mL}$ of $15.3 \% \mathrm{H}_{2} \mathrm{~S}$ mixture, Counts $=583266$ \\
\hline GC Setting & $\mathrm{T}_{\text {oven }}=30^{\circ} \mathrm{C}, \mathrm{T}_{T C D}=100^{\circ} \mathrm{C}$ \\
& $\mathrm{H}_{2}=35 \mathrm{~mL} / \mathrm{min}$ \\
\hline \hline $\mathrm{H}_{2} \mathrm{~S}$ Evolution & $19.0(\mathrm{~mL} / \mathrm{g})$ \\
\hline
\end{tabular}

\begin{tabular}{||c|c|c|c||}
\hline Peak & $\begin{array}{c}\text { Retention Time } \\
(\mathrm{min})\end{array}$ & $\begin{array}{c}\text { Peak Area } \\
\text { (counts) }\end{array}$ & $\begin{array}{c}\mathrm{H}_{2} \text { S Evolution } \\
(\mathrm{mL} / \mathrm{g})\end{array}$ \\
\hline 1 & 8.5 & 1008591 & 6.65 \\
2 & 7.97 & 1208886 & 7.97 \\
3 & $31.16-16.17$ & 667316 & 4.40 \\
\hline
\end{tabular}


Run 7-3 ATTM $/ \mathrm{Al}_{2} \mathrm{O}_{3}$, Temperature-Programmed Dosorption

\begin{tabular}{||l|l||}
\hline Date & $3 / 2 / 94$ \\
\hline Catalyst Weight & $0.1989 \mathrm{~g}$ \\
\hline Pretreatment & $\mathrm{H}_{2}$ reduction at $15^{\circ} \mathrm{C} / \mathrm{min}$ to $550^{\circ} \mathrm{C}+\mathrm{TPD}$ to $550^{\circ} \mathrm{C}$ \\
\hline Starting Temperature of $\mathrm{TPD}$ & $\mathrm{T}_{0}=23^{\circ} \mathrm{C}$ \\
\hline Calibration & $5 \mathrm{~mL}$ of $15.3 \% \mathrm{H}_{2} \mathrm{~S}$ mixture, Counts $=550403$ \\
\hline GC Setting & $\mathrm{T}_{\text {oven }}=30^{\circ} \mathrm{C}, \mathrm{T}_{T C D}=100^{\circ} \mathrm{C}$ \\
& $\mathrm{H}_{2}=35 \mathrm{~mL} / \mathrm{min}$ \\
\hline \hline $\mathrm{H}_{2} \mathrm{~S}$ Evolution & $19.1(\mathrm{~mL} / \mathrm{g})$ \\
\hline
\end{tabular}

\begin{tabular}{||c|c|c|c||}
\hline Peak & $\begin{array}{c}\text { Retention Time } \\
(\mathrm{min})\end{array}$ & $\begin{array}{c}\text { Peak Area } \\
\text { (counts) }\end{array}$ & $\begin{array}{c}\mathrm{H}_{2} \mathrm{~S} \text { Evolution } \\
\text { (mL/g) }\end{array}$ \\
\hline 1 & 8.5 & 1008591 & 6.65 \\
2 & 7.97 & 1208886 & 7.97 \\
3 & $31.16-36.17$ & 667316 & 4.40 \\
\hline
\end{tabular}




\begin{tabular}{||l|l||}
\hline Date & $3 / 8 / 94$ \\
\hline Catalyst Weight & $0.1995 \mathrm{~g}$ \\
\hline Pretreatment & $10^{\circ} \mathrm{C} / \mathrm{min}+\mathrm{TPR}$ to $550^{\circ} \mathrm{C}+\mathrm{TPD}$ to $550^{\circ} \mathrm{C}$ \\
\hline Starting Temperature of TPD & $\mathrm{T}_{0}=25^{\circ} \mathrm{C}$ \\
\hline Calibration & $5 \mathrm{~mL}$ of $15.3 \% \mathrm{H}_{2} \mathrm{~S}$ mixture, Counts $=636078$ \\
\hline GC Setting & $\mathrm{T}_{\text {oven }}=30^{\circ} \mathrm{C}, \mathrm{T}_{T C D}=100^{\circ} \mathrm{C}$ \\
& $\mathrm{H}_{2}=35 \mathrm{~mL} / \mathrm{min}$ \\
\hline \hline $\mathrm{H}_{2} \mathrm{~S}$ Evolution & $15.0(\mathrm{~mL} / \mathrm{g})$ \\
\hline
\end{tabular}

\begin{tabular}{||c|c|c|c||}
\hline Peak & $\begin{array}{c}\text { Retention Time } \\
(\mathrm{min})\end{array}$ & $\begin{array}{c}\text { Peak Area } \\
\text { (counts) }\end{array}$ & $\begin{array}{c}\mathrm{H}_{2} \mathrm{~S} \text { Evolution } \\
(\mathrm{mL} / \mathrm{g})\end{array}$ \\
\hline 1 & 9.07 & 762975 & 4.59 \\
2 & 7.97 & 1205862 & 7.26 \\
3 & $27.57-35.11$ & 526350 & 3.17 \\
\hline
\end{tabular}


Run 7-5 Harshaw, Temperature-Programmed Desorption

\begin{tabular}{||l|l||}
\hline Date & $3 / 10 / 94$ \\
\hline Catalyst Weight & $0.2007 \mathrm{~g}$ \\
\hline Pretreatment & Reductive sulfiding $+\mathrm{TPR}$ to $550^{\circ} \mathrm{C}+\mathrm{TPD}$ to $550^{\circ} \mathrm{C}$ \\
\hline Starting Temperature of TPD & $\mathrm{T}_{0}=41^{\circ} \mathrm{C}$ \\
\hline Calibration & $5 \mathrm{~mL}$ of $15.3 \% \mathrm{H}_{2} \mathrm{~S}$ mixture, Counts $=584479$ \\
\hline GC Setting & $\mathrm{T}_{\text {oven }}=30^{\circ} \mathrm{C}, \mathrm{T}_{T C D}=100^{\circ} \mathrm{C}$ \\
& $\mathrm{H}_{2}=35 \mathrm{~mL} / \mathrm{min}$ \\
\hline \hline $\mathrm{H}_{2} \mathrm{~S}$ Evolution & $7.26(\mathrm{~mL} / \mathrm{g})$ \\
\hline
\end{tabular}

\begin{tabular}{||c|c|c|c||}
\hline Peak & $\begin{array}{c}\text { Retention Time } \\
(\mathrm{min})\end{array}$ & $\begin{array}{c}\text { Peak Area } \\
\text { (counts) }\end{array}$ & $\begin{array}{c}\mathrm{H}_{2} \mathrm{~S} \text { Evolution } \\
(\mathrm{mL} / \mathrm{g})\end{array}$ \\
\hline 1 & 7.42 & 242732 & 1.58 \\
2 & $13.58-18.86$ & 380842 & 2.96 \\
3 & 34.64 & 487980 & 3.19 \\
\hline
\end{tabular}




\begin{tabular}{||l|l||}
\hline Date & $3 / 16 / 94$ \\
\hline Catalyst Weight & $0.1993 \mathrm{~g}$ \\
\hline Pretreatment & Reductive sulfiding $+\mathrm{TPR}$ to $550^{\circ} \mathrm{C}+\mathrm{TPD}$ to $550^{\circ} \mathrm{C}$ \\
\hline Starting Temperature of TPD & $\mathrm{T}_{0}=30^{\circ} \mathrm{C}$ \\
\hline Calibration & $5 \mathrm{~mL}$ of $15.3 \% \mathrm{H}_{2} \mathrm{~S}$ mixture, Counts $=719345$ \\
\hline GC Setting & $\mathrm{T}_{\text {oven }}=30^{\circ} \mathrm{C}, \mathrm{T}_{T C D}=100^{\circ} \mathrm{C}$ \\
& $\mathrm{H}_{2}=35 \mathrm{~mL} / \mathrm{min}$ \\
\hline $\mathrm{H}_{2} \mathrm{~S}$ Evolution & $10.74(\mathrm{~mL} / \mathrm{g})$ \\
\hline
\end{tabular}

\begin{tabular}{||c|c|c|c||}
\hline Peak & $\begin{array}{c}\text { Retention Time } \\
(\min )\end{array}$ & $\begin{array}{c}\text { Peak Area } \\
\text { (counts) }\end{array}$ & $\begin{array}{c}\mathrm{H}_{2} \text { S Evolution } \\
(\mathrm{mL} / \mathrm{g})\end{array}$ \\
\hline 1 & 9.36 & 1033697 & 5.51 \\
2 & 15.69 & 785641 & 4.19 \\
3 & 34.92 & 196491 & 1.04 \\
\hline
\end{tabular}




\begin{tabular}{||l|l||}
\hline Date & $3 / 17 / 94$ \\
\hline Catalyst Weight & $0.2000 \mathrm{~g}$ \\
\hline Pretreatment & $10^{\circ} \mathrm{C} / \mathrm{min}$ decomposition + TPR to $420^{\circ} \mathrm{C}+$ TPD to $420^{\circ} \mathrm{C}$ \\
\hline Starting Temperature of TPD & $\mathrm{T}_{0}=25^{\circ} \mathrm{C}$ \\
\hline Calibration & $5 \mathrm{~mL}$ of $15.3 \% \mathrm{H}_{2} \mathrm{~S}$ mixture, Counts $=719345$ \\
\hline GC Setting & $\begin{array}{l}\mathrm{T}_{\text {oven }}=30^{\circ} \mathrm{C}, \mathrm{T}_{T C D}=100^{\circ} \mathrm{C} \\
\mathrm{H}_{2}=35 \mathrm{~mL} / \mathrm{min}\end{array}$ \\
\hline \hline $\mathrm{H}_{2} \mathrm{~S}$ Evolution & $10.11(\mathrm{~mL} / \mathrm{g})$ \\
\hline
\end{tabular}

\begin{tabular}{||c|c|c|c||}
\hline Peak & $\begin{array}{c}\text { Retention Time } \\
(\mathrm{min})\end{array}$ & $\begin{array}{c}\text { Peak Area } \\
\text { (counts) }\end{array}$ & $\begin{array}{c}\mathrm{H}_{2} \text { S Evolution } \\
(\mathrm{mL} / \mathrm{g})\end{array}$ \\
\hline 1 & 9.89 & 494583 & 3.18 \\
2 & 14.63 & 755657 & 4.85 \\
3 & 29.69 & 323303 & 2.08 \\
\hline
\end{tabular}




\begin{tabular}{||l|l||}
\hline Date & $6 / 9 / 93$ \\
\hline Catalyst Weight & $0.1992 \mathrm{~g}$ \\
\hline Pretreatment & $\mathrm{H}_{2}$ reduction at $15^{\circ} \mathrm{C} / \mathrm{min}$ to $550^{\circ} \mathrm{C}$ \\
\hline Reaction Temperature & $\mathrm{T}=150^{\circ} \mathrm{C}$ \\
\hline Calibration & $1 \mathrm{~mL} \mathrm{H}: \mathrm{C}_{3} \mathrm{H}_{6}=1.5: 1$, Counts $=681050$ \\
\hline
\end{tabular}

\begin{tabular}{||c|c|c||}
\hline $\begin{array}{c}\text { Time } \\
(\min )\end{array}$ & $\begin{array}{c}\text { Unconverted Propylene } \\
\text { (counts) }\end{array}$ & $\begin{array}{c}\text { Conversion } \\
(\%)\end{array}$ \\
\hline 5 & 16027 & 97.6 \\
10 & 153823 & 77.4 \\
20 & 247084 & 63.7 \\
35 & 253584 & 62.7 \\
50 & 302627 & 55.5 \\
65 & 335294 & 50.7 \\
80 & 386687 & 43.2 \\
100 & 437597 & 45.7 \\
125 & 469127 & 31.1 \\
165 & 572295 & 16.0 \\
\hline
\end{tabular}


Run 8-3 ATTM $/ \mathrm{Al}_{2} \mathrm{O}_{3}$, Propylene HYD Activity

\begin{tabular}{||l|l||}
\hline Date & $6 / 14 / 93$ \\
\hline Catalyst Weight & $0.1997 \mathrm{~g}$ \\
\hline Pretreatment & $\mathrm{H}_{2}$ reduction at $15^{\circ} \mathrm{C} / \mathrm{min}$ to $550^{\circ} \mathrm{C}$ \\
\hline Reaction Temperature & $\mathrm{T}=50^{\circ} \mathrm{C}$ \\
\hline Calibration & $1 \mathrm{~mL} \mathrm{H}_{2}: \mathrm{C}_{3} \mathrm{H}_{6}=1.5: 1$, Counts $=702797$ \\
\hline
\end{tabular}

\begin{tabular}{||c|c|c||}
\hline $\begin{array}{c}\text { Time } \\
(\mathrm{min})\end{array}$ & $\begin{array}{c}\text { Unconverted Propylene } \\
\text { (counts) }\end{array}$ & $\begin{array}{c}\text { Conversion } \\
(\%)\end{array}$ \\
\hline 5 & 0.00 & 100.0 \\
20 & 5536 & 99.3 \\
40 & 10180 & 98.5 \\
60 & 16995 & 97.5 \\
100 & 31319 & 95.5 \\
125 & 57995 & 91.7 \\
285 & 133834 & 80.9 \\
365 & 187656 & 73.2 \\
\hline
\end{tabular}


Run 8-5 Harshaw, Propylene HYD Activity

\begin{tabular}{||l|l||}
\hline Date & $6 / 14 / 93$ \\
\hline Catalyst Weight & $0.2001 \mathrm{~g}$ \\
\hline Pretreatment & Reductive Sulfiding + TPR \\
\hline Reaction Temperature & $\mathrm{T}=50^{\circ} \mathrm{C}$ \\
\hline Calibration & $1 \mathrm{~mL} \mathrm{H}: \mathrm{C}_{3} \mathrm{H}_{6}=1.5: 1$, Counts $=808497$ \\
\hline
\end{tabular}

\begin{tabular}{||c|c|c|}
\hline $\begin{array}{c}\text { Time } \\
(\mathrm{min})\end{array}$ & $\begin{array}{c}\text { Unconverted Propylene } \\
\text { (counts) }\end{array}$ & $\begin{array}{c}\text { Conversion } \\
(\%)\end{array}$ \\
\hline 4 & 349727 & 56.7 \\
60 & 513264 & 36.5 \\
120 & 574222 & 29.0 \\
180 & 603589 & 25.5 \\
240 & 636202 & 21.3 \\
300 & 660625 & 18.3 \\
360 & 667859 & 17.4 \\
420 & 674901 & 16.5 \\
960 & 787144 & 2.6 \\
\hline
\end{tabular}


Run 8-8 ATTM $/ \mathrm{Al}_{2} \mathrm{O}_{3}$, Propylene HYD Activity

\begin{tabular}{||l|l||}
\hline Date & $7 / 18 / 93$ \\
\hline Catalyst Weight & $0.0495 \mathrm{~g}$ \\
\hline Pretreatment & $\mathrm{H}_{2}$ reduction at $15^{\circ} \mathrm{C} / \mathrm{min}$ to $550^{\circ} \mathrm{C}$ \\
\hline Reaction Temperature & $\mathrm{T}=50^{\circ} \mathrm{C}$ \\
\hline Calibration & $1 \mathrm{~mL} \mathrm{H}: \mathrm{C}_{3} \mathrm{H}_{6}=5: 1$ \\
\hline
\end{tabular}

\begin{tabular}{||c|c|c|c||}
\hline $\begin{array}{c}\text { Time } \\
(\mathrm{min})\end{array}$ & $\begin{array}{c}\text { Unconverted Propylene } \\
\text { (counts) }\end{array}$ & $\begin{array}{c}\text { Calibration } \\
\text { (counts) }\end{array}$ & $\begin{array}{c}\text { Conversion } \\
(\%)\end{array}$ \\
\hline 5 & 147757 & 305686 & 51.6 \\
40 & 286026 & 387191 & 26.1 \\
60 & 292612 & 387191 & 24.4 \\
\hline
\end{tabular}


Run 8-9 ATTM $/ \mathrm{Al}_{2} \mathrm{O}_{3}$, Propylene HYD Activity, Pulse

\begin{tabular}{||l|l||}
\hline Date & $7 / 18 / 93$ \\
\hline Catalyst Weight & $0.0503 \mathrm{~g}$ \\
\hline Pretreatment & $\mathrm{H}_{2}$ reduction at $15^{\circ} \mathrm{C} / \mathrm{min}$ to $550^{\circ} \mathrm{C}$ \\
\hline Reaction Temperature & $\mathrm{T}=100^{\circ} \mathrm{C}$ \\
\hline Calibration & $1 \mathrm{~mL} \mathrm{H}_{2}: \mathrm{C}_{3} \mathrm{H}_{6}=5: 1$ \\
\hline
\end{tabular}

\begin{tabular}{||c|c||}
\hline Reaction Temperature $\left({ }^{\circ} \mathrm{C}\right)$ & Propane Area (counts) \\
\hline 50 & 55546 \\
100 & 364588 \\
150 & 49915 \\
\hline
\end{tabular}




\begin{tabular}{||l|l||}
\hline Date & $7 / 18 / 93$ \\
\hline Catalyst Weight & $0.0504 \mathrm{~g}$ \\
\hline Pretreatment & $\mathrm{H}_{2}$ reduction at $15^{\circ} \mathrm{C} / \mathrm{min}$ to $550^{\circ} \mathrm{C}$ \\
\hline Reaction Temperature & $\mathrm{T}=100^{\circ} \mathrm{C}$ \\
\hline Calibration & $1 \mathrm{~mL} \mathrm{H}_{2}: \mathrm{C}_{3} \mathrm{H}_{6}=5: 1$, Counts $=310575$ \\
\hline
\end{tabular}

\begin{tabular}{||c|c|c||}
\hline $\begin{array}{c}\text { Time } \\
(\min )\end{array}$ & $\begin{array}{c}\text { Unconverted Propylene } \\
\text { (counts) }\end{array}$ & $\begin{array}{c}\text { Conversion } \\
(\%)\end{array}$ \\
\hline 3 & 119015 & 61.7 \\
9 & 184075 & 40.7 \\
24 & 222886 & 28.2 \\
39 & 250959 & 19.1 \\
56 & 269974 & 13.1 \\
81 & 281576 & 9.3 \\
103 & 280993 & 9.5 \\
115 & 297776 & 4.1 \\
\hline
\end{tabular}


Run 8-12 $\mathrm{MoO}_{3} / \mathrm{Al}_{2} \mathrm{O}_{3}$, Propylene HYD Activity

\begin{tabular}{||l|l||}
\hline Date & $6 / 14 / 93$ \\
\hline Catalyst Weight & $0.1997 \mathrm{~g}$ \\
\hline Pretreatment & Reductive Sulfiding $+\mathrm{TPR}$ \\
\hline Reaction Temperature & $\mathrm{T}=50^{\circ} \mathrm{C}$ \\
\hline Calibration & $1 \mathrm{~mL} \mathrm{H}_{2}: \mathrm{C}_{3} \mathrm{H}_{6}=1.5: 1$, Counts $=774514$ \\
\hline
\end{tabular}

\begin{tabular}{||c|c|c||}
\hline $\begin{array}{c}\text { Time } \\
(\mathrm{min})\end{array}$ & $\begin{array}{c}\text { Unconverted Propylene } \\
\text { (counts) }\end{array}$ & $\begin{array}{c}\text { Conversion } \\
(\%)\end{array}$ \\
\hline 3 & 157097 & 79.7 \\
10 & 660582 & 14.7 \\
29 & 753220 & 2.7 \\
41 & 774514 & 0.0 \\
51 & 765446 & 0.0 \\
\hline
\end{tabular}

141 
Run 8-13 ATTM $/ \mathrm{Al}_{2} \mathrm{O}_{3}$, Propylene HYD Activity

\begin{tabular}{||l|l||}
\hline Date & $7 / 21 / 93$ \\
\hline Catalyst Weight & $0.1991 \mathrm{~g}$ \\
\hline Pretreatment & Flash decomposition $+\mathrm{TPR}$ \\
\hline Reaction Temperature & $\mathrm{T}=50^{\circ} \mathrm{C}$ \\
\hline Calibration & $1 \mathrm{~mL} \mathrm{H}{ }_{2}: \mathrm{C}_{3} \mathrm{H}_{6}=1.5: 1$, Counts $=778868$ \\
\hline
\end{tabular}

\begin{tabular}{||c|c|c||}
\hline $\begin{array}{c}\text { Time } \\
(\mathrm{min})\end{array}$ & $\begin{array}{c}\text { Unconverted Propylene } \\
\text { (counts) }\end{array}$ & $\begin{array}{c}\text { Conversion } \\
(\%)\end{array}$ \\
\hline 5 & 0.0 & 100.0 \\
28 & 0.0 & 100.0 \\
44 & 0.0 & 100.0 \\
64 & 51421 & 93.3 \\
107 & 57542 & 92.6 \\
172 & 145355 & 81.3 \\
\hline
\end{tabular}




\begin{tabular}{||l|l||}
\hline Date & $7 / 22 / 93$ \\
\hline Catalyst Weight & $0.2004 \mathrm{~g}$ \\
\hline Pretreatment & $10^{\circ} \mathrm{C} / \mathrm{min}$ decomposition $+\mathrm{TPR}$ \\
\hline Reaction Temperature & $\mathrm{T}=50^{\circ} \mathrm{C}$ \\
\hline Calibration & $1 \mathrm{~mL} \mathrm{H}:_{2} \mathrm{C}_{3} \mathrm{H}_{6}=3: 1$, Counts $=457933$ \\
\hline
\end{tabular}

\begin{tabular}{||c|c|c||}
\hline $\begin{array}{c}\text { Time } \\
(\mathrm{min})\end{array}$ & $\begin{array}{c}\text { Unconverted Propylene } \\
\text { (counts) }\end{array}$ & $\begin{array}{c}\text { Conversion } \\
(\%)\end{array}$ \\
\hline 4 & 0.0 & 100.0 \\
32 & 0.0 & 100.0 \\
63 & 0.0 & 100.0 \\
118 & 0.0 & 100.0 \\
153 & 0.0 & 100.0 \\
204 & 0.0 & 100.0 \\
248 & 0.0 & 100.0 \\
314 & 0.0 & 100.0 \\
376 & 0.0 & 100.0 \\
1020 & 105784 & 76.8 \\
\hline
\end{tabular}


Run 8-15 ATTM $/ \mathrm{Al}_{2} \mathrm{O}_{3}$, Propylene HYD Activity (Part I)

\begin{tabular}{||l|l||}
\hline Date & $7 / 26 / 93$ \\
\hline Catalyst Weight & $0.0795 \mathrm{~g}$ \\
\hline Pretreatment & $10^{\circ} \mathrm{C} / \mathrm{min}$ decomposition $+\mathrm{TPR}$ \\
\hline Reaction Temperature & $\mathrm{T}=50^{\circ} \mathrm{C}$ \\
\hline Calibration & $1 \mathrm{~mL} \mathrm{H}:_{2} \mathrm{C}_{3} \mathrm{H}_{6}=1.5: 1$, Counts $=879738$ \\
\hline
\end{tabular}

\begin{tabular}{||c|c|c||}
\hline $\begin{array}{c}\text { Time } \\
(\mathrm{min})\end{array}$ & $\begin{array}{c}\text { Unconverted Propylene } \\
\text { (counts) }\end{array}$ & $\begin{array}{c}\text { Conversion } \\
(\%)\end{array}$ \\
\hline 3 & 16042 & 98.2 \\
14 & 171312 & 80.5 \\
39 & 325835 & 82.9 \\
66 & 383354 & 56.4 \\
91 & 510664 & 41.9 \\
102 & 566308 & 35.6 \\
150 & 685163 & 22.1 \\
218 & 625237 & 28.9 \\
252 & 731978 & 16.8 \\
304 & 645060 & 26.7 \\
359 & 637739 & 27.5 \\
\hline
\end{tabular}




\begin{tabular}{||c|c|c||}
\hline $\begin{array}{c}\text { Time } \\
(\mathrm{min})\end{array}$ & $\begin{array}{c}\text { Unconverted Propylene } \\
\text { (counts) }\end{array}$ & $\begin{array}{c}\text { Conversion } \\
(\%)\end{array}$ \\
\hline 21 & 149648 & 83.4 \\
32 & 260629 & 70.1 \\
44 & 298027 & 66.9 \\
131 & 361814 & 59.8 \\
184 & 413560 & 54.1 \\
\hline
\end{tabular}

Table F.1: Propylene Activity After 1st Regeneration, Calibration counts = 901304

\begin{tabular}{||c|c|c||}
\hline $\begin{array}{c}\text { Time } \\
(\mathrm{min})\end{array}$ & $\begin{array}{c}\text { Unconverted Propylene } \\
\text { (counts) }\end{array}$ & $\begin{array}{c}\text { Conversion } \\
(\%)\end{array}$ \\
\hline 8 & 97279 & 89.9 \\
19 & 195203 & 79.7 \\
70 & 181369 & 81.2 \\
82 & 208134 & 78.4 \\
115 & 323290 & 66.5 \\
125 & 339816 & 64.8 \\
182 & 355123 & 63.2 \\
\hline
\end{tabular}

Table F.2: Propylene Activity After 2nd Regeneration, Calibration counts $=965730$ 


\begin{tabular}{||l|l||}
\hline Date & $9 / 1 / 93$ \\
\hline Catalyst Weight & $0.1994 \mathrm{~g}$ \\
\hline Pretreatment & $10^{\circ} \mathrm{C} / \mathrm{min}$ decomposition $+\mathrm{TPR}$ \\
\hline Reaction Temperature & $\mathrm{T}=50^{\circ} \mathrm{C}$ \\
\hline Calibration & $5 \mathrm{~mL} \mathrm{H}: \mathrm{C}_{3} \mathrm{H}_{6}=1.5: 1$, Counts $=3515578$ \\
\hline
\end{tabular}

\begin{tabular}{||c|c|c||}
\hline $\begin{array}{c}\text { Time } \\
(\mathrm{min})\end{array}$ & $\begin{array}{c}\text { Unconverted Propylene } \\
\text { (counts) }\end{array}$ & $\begin{array}{c}\text { Conversion } \\
(\%)\end{array}$ \\
\hline 10 & 0 & 100.0 \\
19 & 0 & 100.0 \\
39 & 41071 & 98.8 \\
65 & 256598 & 92.7 \\
113 & 785244 & 77.6 \\
180 & 664587 & 81.0 \\
\hline
\end{tabular}


$\underline{\text { Run 9-2 Co-ATTM } / \mathrm{Al}_{2} \mathrm{O}_{3} \text {, Temperature-Programmed Desorption }}$

\begin{tabular}{||l|l||}
\hline Date & $5 / 31 / 94$ \\
\hline Catalyst Weight & $0.2003 \mathrm{~g}$ \\
\hline Pretreatment & $\mathrm{H}_{2}$ reduction at $15^{\circ} \mathrm{C} / \mathrm{min}$ to $550^{\circ} \mathrm{C}+\mathrm{TPD}$ \\
\hline Starting Temperature of TPD & $\mathrm{T}_{0}=26^{\circ} \mathrm{C}$ \\
\hline Calibration & $1 \mathrm{~mL}$ of $15.3 \% \mathrm{H}_{2} \mathrm{~S}$ mixture, Counts $=134911$ \\
\hline GC Setting & $\begin{array}{l}\mathrm{T}_{\text {oven }}=30^{\circ} \mathrm{C}, \mathrm{T}_{T C D}=100^{\circ} \mathrm{C} \\
\mathrm{H}_{2}=35 \mathrm{~mL} / \mathrm{min}\end{array}$ \\
\hline \hline $\mathrm{H}_{2} \mathrm{~S}$ Evolution & $15.3(\mathrm{~mL} / \mathrm{g})$ \\
\hline
\end{tabular}

\begin{tabular}{||c|c|c|c||}
\hline Peak & $\begin{array}{c}\text { Retention Time } \\
(\mathrm{min})\end{array}$ & $\begin{array}{c}\text { Peak Area } \\
\text { (counts) }\end{array}$ & $\begin{array}{c}\mathrm{H}_{2} \mathrm{~S} \text { Evolution } \\
(\mathrm{mL} / \mathrm{g})\end{array}$ \\
\hline 1 & 11.74 & 104177 & 5.91 \\
2 & 16.26 & 690354 & 3.90 \\
3 & 35.55 & 971874 & 5.50 \\
\hline
\end{tabular}




\begin{tabular}{||l|l||}
\hline Date & $6 / 1 / 94$ \\
\hline Catalyst Weight & $0.2003 \mathrm{~g}$ \\
\hline Pretreatment & $\mathrm{H}_{2}$ reduction at $15^{\circ} \mathrm{C} / \mathrm{min}$ to $550^{\circ} \mathrm{C}$ \\
\hline Sampling Loop & $5 \mathrm{~mL}$ \\
\hline GC Setting & $\begin{array}{l}\mathrm{T}_{\text {oven }}=70^{\circ} \mathrm{C}, \mathrm{T}_{T C D}=100^{\circ} \mathrm{C} \\
\mathrm{He}=35 \mathrm{~mL} / \mathrm{min}\end{array}$ \\
\hline \hline LTOC & $2.31(\mathrm{~mL} / \mathrm{g})$ \\
\hline
\end{tabular}

\begin{tabular}{||c|c|c||}
\hline Pulse No. & Peak Area (counts) & $\Delta_{i}$ \\
\hline $1-5$ & 0.0 & 1.000 \\
6 & 60000 & 0.530 \\
7 & 120189 & 0.073 \\
8 & 90320 & 0.303 \\
9 & 107536 & 0.171 \\
10 & 121985 & 0.060 \\
11 & 129777 & 0.000 \\
\hline
\end{tabular}


Run 9-5 Co-ATTM $/ \mathrm{Al}_{2} \mathrm{O}_{3}$, Low Temperature Oxygen Chemisorption

\begin{tabular}{||l|l||}
\hline Date & $6 / 1 / 94$ \\
\hline Catalyst Weight & $0.1999 \mathrm{~g}$ \\
\hline Pretreatment & $10^{\circ} \mathrm{C} / \mathrm{min}$ decomposition $+\mathrm{TPR}$ \\
\hline Sampling Loop & $5 \mathrm{~mL}$ \\
\hline GC Setting & $\begin{array}{l}\mathrm{T}_{\text {oven }}=70^{\circ} \mathrm{C}, \mathrm{T}_{T C D}=100^{\circ} \mathrm{C} \\
\mathrm{He}=35 \mathrm{~mL} / \mathrm{min}\end{array}$ \\
\hline \hline LTOC & $2.15(\mathrm{~mL} / \mathrm{g})$ \\
\hline
\end{tabular}

\begin{tabular}{||c|c|c||}
\hline Pulse No. & Peak Area (counts) & $\Delta_{i}$ \\
\hline $1-2$ & 0.0 & 1.000 \\
3 & 21558 & 0.869 \\
4 & 22646 & 0.863 \\
5 & 19920 & 0.879 \\
6 & 63005 & 0.618 \\
7 & 125707 & 0.238 \\
8 & 152349 & 0.077 \\
9 & 155228 & 0.059 \\
10 & 161211 & 0.023 \\
11 & 152419 & 0.076 \\
12 & 165029 & 0.000 \\
\hline
\end{tabular}

149 
Run 9-7 Co-ATTM $/ \mathrm{Al}_{2} \mathrm{O}_{3}$, Temperature-Programmed Desorption

\begin{tabular}{||l|l||}
\hline Date & $5 / 31 / 94$ \\
\hline Catalyst Weight & $0.1999 \mathrm{~g}$ \\
\hline Pretreatment & $10^{\circ} \mathrm{C} / \mathrm{min}$ decomposition $+\mathrm{TPD}$ \\
\hline Starting Temperature of $\mathrm{TPD}$ & $\mathrm{T}_{0}=31.5^{\circ} \mathrm{C}$ \\
\hline Calibration & $1 \mathrm{~mL}$ of $15.3 \% \mathrm{H}_{2} \mathrm{~S}$ mixture, Counts $=145487$ \\
\hline GC Setting & $\mathrm{T}_{\text {oven }}=30^{\circ} \mathrm{C}, \mathrm{T}_{T C D}=100^{\circ} \mathrm{C}$ \\
$\mathrm{H}_{2}=35 \mathrm{~mL} / \mathrm{min}$ \\
\hline \hline $\mathrm{H}_{2} \mathrm{~S}$ Evolution & $15.4(\mathrm{~mL} / \mathrm{g})$ \\
\hline
\end{tabular}

\begin{tabular}{||c|c|c|c||}
\hline Peak & $\begin{array}{c}\text { Retention Time } \\
(\mathrm{min})\end{array}$ & $\begin{array}{c}\text { Peak Area } \\
\text { (counts) }\end{array}$ & $\begin{array}{c}\mathrm{H}_{2} \mathrm{~S} \text { Evolution } \\
(\mathrm{mL} / \mathrm{g})\end{array}$ \\
\hline 1 & $9.6-12.7$ & 981155 & 5.15 \\
2 & 16.4 & 1293009 & 6.79 \\
3 & $31.5-35.4$ & 865602 & 3.49 \\
\hline
\end{tabular}


Run 9-8 Co-ATTM $/ \mathrm{Al}_{2} \mathrm{O}_{3}$, Propylene HYD Activity

\begin{tabular}{||l|l||}
\hline Date & $7 / 24 / 94$ \\
\hline Catalyst Weight & $0.0797 \mathrm{~g}$ \\
\hline Pretreatment & $10^{\circ} \mathrm{C} / \mathrm{min}$ decomposition $+\mathrm{TPR}$ \\
\hline Reaction Temperature & $\mathrm{T}=50^{\circ} \mathrm{C}$ \\
\hline Calibration & $5 \mathrm{~mL} \mathrm{H}: \mathrm{C}_{3} \mathrm{H}_{6}=1.5: 1$, Counts $=855426$ \\
\hline
\end{tabular}

\begin{tabular}{||c|c|c||}
\hline $\begin{array}{c}\text { Time } \\
(\min )\end{array}$ & $\begin{array}{c}\text { Unconverted Propylene } \\
\text { (counts) }\end{array}$ & $\begin{array}{c}\text { Conversion } \\
(\%)\end{array}$ \\
\hline 4 & 24335 & 97.2 \\
36 & 111412 & 87.0 \\
53 & 320011 & 62.5 \\
79 & 332687 & 61.1 \\
129 & 506849 & 40.7 \\
181 & 596300 & 30.3 \\
236 & 562638 & 34.2 \\
298 & 648602 & 24.1 \\
\hline
\end{tabular}

151 
Run 9-9 Co- $\mathrm{MoO}_{3} / \mathrm{Al}_{2} \mathrm{O}_{3}$, Propylene HYD Activity

\begin{tabular}{||l|l||}
\hline Date & $7 / 24 / 94$ \\
\hline Catalyst Weight & $0.0802 \mathrm{~g}$ \\
\hline Pretreatment & Reductive Sulfiding $+\mathrm{TPR}$ \\
\hline Reaction Temperature & $\mathrm{T}=50^{\circ} \mathrm{C}$ \\
\hline Calibration & $5 \mathrm{~mL} \mathrm{H}{ }_{2}: \mathrm{C}_{3} \mathrm{H}_{6}=1.5: 1$, Counts $=887476$ \\
\hline
\end{tabular}

\begin{tabular}{||c|c|c||}
\hline $\begin{array}{c}\text { Time } \\
(\min )\end{array}$ & $\begin{array}{c}\text { Unconverted Propylene } \\
\text { (counts) }\end{array}$ & $\begin{array}{c}\text { Conversion } \\
(\%)\end{array}$ \\
\hline 5 & 495652 & 44.2 \\
11 & 597179 & 32.7 \\
23 & 688898 & 22.3 \\
33 & 616931 & 30.5 \\
43 & 670939 & 24.4 \\
112 & 781206 & 11.9 \\
158 & 768043 & 13.4 \\
\hline
\end{tabular}


Run 9-10 Co-ATTM/ $/ \mathrm{Al}_{2} \mathrm{O}_{3}$, Thiophene HDS Activity, Continuous

\begin{tabular}{||l|l||}
\hline Date & $11 / 29 / 94$ \\
\hline Catalyst Weight & $0.2030 \mathrm{~g}$ \\
\hline Pretreatment & $10^{\circ} \mathrm{C} / \mathrm{min}$ decomposition $+\mathrm{TPR}$ \\
\hline Calibration & $1 \mathrm{~mL}$ thiophene $/ \mathrm{H}_{2}$ \\
\hline \hline Average Conversion $(\%)$ & 54.1 \\
\hline
\end{tabular}

\begin{tabular}{||c|c|c|c||}
\hline $\begin{array}{c}\text { Time } \\
(\mathrm{hr})\end{array}$ & $\begin{array}{c}\text { Unconverted Thiophene } \\
\text { (counts) }\end{array}$ & $\begin{array}{c}\text { Calibration } \\
\text { (counts) }\end{array}$ & $\begin{array}{c}\text { Conversion } \\
(\%)\end{array}$ \\
\hline 0.167 & 42285 & 112722 & 64.2 \\
0.5 & 51338 & 118345 & 56.6 \\
1.5 & 56200 & 118345 & 52.5 \\
2.0 & 52761 & 118345 & 55.4 \\
2.5 & 60927 & 118345 & 48.5 \\
3.0 & 57651 & 118345 & 51.3 \\
3.5 & 58865 & 118345 & 50.3 \\
\hline
\end{tabular}




\begin{tabular}{||l|l||}
\hline Date & $11 / 29 / 94$ \\
\hline Catalyst Weight & $0.2002 \mathrm{~g}$ \\
\hline Pretreatment & $10^{\circ} \mathrm{C} / \mathrm{min}$ decomposition $+\mathrm{TPR}$ \\
\hline Calibration & $1 \mathrm{~mL}$ thiophene $/ \mathrm{H}_{2}$ \\
\hline \hline Average Conversion $(\%)$ & 13.5 \\
\hline
\end{tabular}

\begin{tabular}{||c|c|c|c||}
\hline $\begin{array}{c}\text { Time } \\
(\mathrm{hr})\end{array}$ & $\begin{array}{c}\text { Unconverted Thiophene } \\
\text { (counts) }\end{array}$ & $\begin{array}{c}\text { Calibration } \\
\text { (counts) }\end{array}$ & $\begin{array}{c}\text { Conversion } \\
(\%)\end{array}$ \\
\hline 0.167 & 87235 & 106578 & 18.1 \\
0.5 & 91696 & 106578 & 13.9 \\
1.0 & 89208 & 106578 & 16.2 \\
1.5 & 91922 & 106578 & 13.7 \\
2.0 & 93709 & 106578 & 12.3 \\
2.67 & 96074 & 106578 & 9.8 \\
3.5 & 95019 & 106578 & 10.8 \\
\hline
\end{tabular}

Table F.3: A comparison to Run 9-10 


\begin{tabular}{||l|l||}
\hline Date & $7 / 30 / 93$ \\
\hline Catalyst Weight & $0.0221 \mathrm{~g}$ \\
\hline Pretreatment & None \\
\hline \hline BET area & $183.0\left(\mathrm{~m}^{2} / \mathrm{g}\right)$ \\
\hline
\end{tabular}

\begin{tabular}{||c|c|c|c|c|c|c||}
\hline $\begin{array}{c}\mathrm{C}_{N_{2}} \\
(\%)\end{array}$ & $\mathrm{P} / \mathrm{P}_{0}$ & $\begin{array}{c}\mathrm{A}_{a d s} \\
\text { (counts) }\end{array}$ & $\begin{array}{c}\mathrm{A}_{\text {des }} \\
\text { (counts) }\end{array}$ & $\begin{array}{c}\mathrm{V}_{\text {cal }} \\
(\mathrm{mL})\end{array}$ & $\begin{array}{c}\mathrm{A}_{\text {cal }} \\
\text { (counts) }\end{array}$ & $1 /\left(\mathrm{X}\left(\mathrm{P} / \mathrm{P}_{0}-1\right)\right)$ \\
\hline 12.48 & 0.120 & 619 & 623 & 1.0 & 634 & 119.3 \\
17.57 & 0.172 & 977 & 951 & 1.0 & 901 & 169.5 \\
27.86 & 0.237 & 861 & 892 & 1.0 & 717 & 214.8 \\
\hline
\end{tabular}

155 


\begin{tabular}{||l|l||}
\hline Date & $8 / 9 / 93$ \\
\hline Catalyst Weight & $0.0215 \mathrm{~g}$ \\
\hline Pretreatment & None \\
\hline \hline BET area & $178.6\left(\mathrm{~m}^{2} / \mathrm{g}\right)$ \\
\hline
\end{tabular}

\begin{tabular}{||c|c|c|c|c|c|c||}
\hline $\begin{array}{c}\mathrm{C}_{N_{2}} \\
(\%)\end{array}$ & $\mathrm{P} / \mathrm{P}_{0}$ & $\begin{array}{c}\mathrm{A}_{\text {ads }} \\
\text { (counts) }\end{array}$ & $\begin{array}{c}\mathrm{A}_{\text {des }} \\
(\text { counts })\end{array}$ & $\begin{array}{c}\mathrm{V}_{\text {cal }} \\
(\mathrm{mL})\end{array}$ & $\begin{array}{c}\mathrm{A}_{\text {cal }} \\
\text { (counts) }\end{array}$ & $1 /\left(\mathrm{X}\left(\mathrm{P} / \mathrm{P}_{0}-1\right)\right)$ \\
\hline 12.9 & 0.127 & 703 & 715 & 1.0 & 675 & 118.1 \\
18.2 & 0.179 & 518 & 523 & 1.0 & 471 & 168.6 \\
29.1 & 0.285 & 965 & 918 & 1.0 & 756 & 278.4 \\
\hline
\end{tabular}


Run 10-3 ATTM $/ \mathrm{Al}_{2} \mathrm{O}_{3}$, BET Area Measurement

\begin{tabular}{||l|l||}
\hline Date & $8 / 10 / 93$ \\
\hline Catalyst Weight & $0.0277 \mathrm{~g}$ \\
\hline Pretreatment & $10^{\circ} \mathrm{C} / \mathrm{min}$ decomposition $+\mathrm{TPR}$ to $420^{\circ} \mathrm{C}$ \\
\hline \hline BET area & $175.4\left(\mathrm{~m}^{2} / \mathrm{g}\right)$ \\
\hline
\end{tabular}

\begin{tabular}{||c|c|c|c|c|c|c||}
\hline $\begin{array}{c}\mathrm{C}_{N_{2}} \\
(\%)\end{array}$ & $\mathrm{P} / \mathrm{P}_{0}$ & $\begin{array}{c}\mathrm{A}_{a d s} \\
\text { (counts) }\end{array}$ & $\begin{array}{c}\mathrm{A}_{\text {des }} \\
\text { (counts) }\end{array}$ & $\begin{array}{c}\mathrm{V}_{\text {cal }} \\
(\mathrm{mL})\end{array}$ & $\begin{array}{c}\mathrm{A}_{\text {cal }} \\
\text { (counts) }\end{array}$ & $\mathrm{I} /\left(\mathrm{X}\left(\mathrm{P} / \mathrm{P}_{0}-1\right)\right)$ \\
\hline 13.1 & 0.128 & 877 & 853 & 1.5 & 1000 & 101.0 \\
17.6 & 0.173 & 621 & 620 & 1.3 & 606 & 132.8 \\
28.8 & 0.283 & 1128 & 1176 & 1.4 & 1.21 & 210 \\
\hline
\end{tabular}


$\underline{\text { Run 10-4 ATTM } / \mathrm{Al}_{2} \mathrm{O}_{3}, \text { BET Area Measurement }}$

\begin{tabular}{||l|l||}
\hline Date & $8 / 10 / 93$ \\
\hline Catalyst Weight & $0.0281 \mathrm{~g}$ \\
\hline Pretreatment & $10^{\circ} \mathrm{C} / \mathrm{min}$ decomposition $+\mathrm{TPR}$ to $550^{\circ} \mathrm{C}$ \\
\hline \hline BET area & $174.9\left(\mathrm{~m}^{2} / \mathrm{g}\right)$ \\
\hline
\end{tabular}

\begin{tabular}{||c|c|c|c|c|c|c||}
\hline $\begin{array}{c}\mathrm{C}_{N_{2}} \\
(\%)\end{array}$ & $\mathrm{P} / \mathrm{P}_{0}$ & $\begin{array}{c}\mathrm{A}_{a d s} \\
\text { (counts) }\end{array}$ & $\begin{array}{c}\mathrm{A}_{\text {des }} \\
\text { (counts) }\end{array}$ & $\begin{array}{c}\mathrm{V}_{\text {cal }} \\
(\mathrm{mL})\end{array}$ & $\begin{array}{c}\mathrm{A}_{\text {cal }} \\
\text { (counts) }\end{array}$ & $1 /\left(\mathrm{X}\left(\mathrm{P} / \mathrm{P}_{0}-1\right)\right)$ \\
\hline 13.6 & 0.133 & 1101 & 1091 & 1.5 & 1376 & 111.4 \\
18.6 & 0.183 & 1222 & 1227 & 1.2 & 1094 & 143.1 \\
29.9 & 0.294 & 1661 & 1627 & 1.2 & 1314 & 240.75 \\
\hline
\end{tabular}

158 


\begin{tabular}{||l|l||}
\hline Date & $8 / 9 / 93$ \\
\hline Catalyst Weight & $0.0282 \mathrm{~g}$ \\
\hline Pretreatment & None \\
\hline \hline BET area & $172.9\left(\mathrm{~m}^{2} / \mathrm{g}\right)$ \\
\hline
\end{tabular}

\begin{tabular}{||c|c|c|c|c|c|c||}
\hline $\begin{array}{c}\mathrm{C}_{N_{2}} \\
(\%)\end{array}$ & $\mathrm{P} / \mathrm{P}_{0}$ & $\begin{array}{c}\mathrm{A}_{a d s} \\
\text { (counts) }\end{array}$ & $\begin{array}{c}\mathrm{A}_{d e s} \\
\text { (counts) }\end{array}$ & $\begin{array}{c}\mathrm{V}_{c a l} \\
(\mathrm{~mL})\end{array}$ & $\begin{array}{c}\mathrm{A}_{\text {cal }} \\
\text { (counts) }\end{array}$ & $1 /\left(\mathrm{X}\left(\mathrm{P} / \mathrm{P}_{0}-1\right)\right)$ \\
\hline 13.9 & 0.133 & 649 & 651 & 1.2 & 598 & 101.0 \\
18.4 & 0.180 & 1110 & 1094 & 1.3 & 1023 & 135.8 \\
30.2 & 0.296 & 1617 & 1645 & 1.4 & 1380 & 217.0 \\
\hline
\end{tabular}


$\underline{\text { Run 10-6 Co-ATTM } / \mathrm{Al}_{2} \mathrm{O}_{3} \text {, BET Area Measurement }}$

\begin{tabular}{||l|l||}
\hline Date & $6 / 16 / 94$ \\
\hline Catalyst Weight & $0.0293 \mathrm{~g}$ \\
\hline Pretreatment & None \\
\hline \hline BET area & $155.0\left(\mathrm{~m}^{2} / \mathrm{g}\right)$ \\
\hline
\end{tabular}

\begin{tabular}{||c|c|c|c|c|c|c||}
\hline $\begin{array}{c}\mathrm{C}_{N_{2}} \\
(\%)\end{array}$ & $\mathrm{P} / \mathrm{P}_{0}$ & $\begin{array}{c}\mathrm{A}_{a d s} \\
\text { (counts) }\end{array}$ & $\begin{array}{c}\mathrm{A}_{d e s} \\
\text { (counts) }\end{array}$ & $\begin{array}{c}\mathrm{V}_{c a l} \\
(\mathrm{~mL})\end{array}$ & $\begin{array}{c}\mathrm{A}_{c a l} \\
\text { (counts) }\end{array}$ & $1 /\left(\mathrm{X}\left(\mathrm{P} / \mathrm{P}_{0}-1\right)\right)$ \\
\hline 29.6 & 0.293 & 1429 & 1347 & 1.5 & 1304 & 231.0 \\
18.6 & 0.184 & 798 & 811 & 1.5 & 855 & 136 \\
13.8 & 0.136 & 568 & 560 & 1.5 & 664 & 107 \\
\hline
\end{tabular}

160 
Run 10-7 Co-ATTM $/ \mathrm{Al}_{2} \mathrm{O}_{3}$, BET Area Measurement

\begin{tabular}{||l|l||}
\hline Date & $6 / 16 / 94$ \\
\hline Catalyst Weight & $0.0223 \mathrm{~g}$ \\
\hline Pretreatment & $10^{\circ} \mathrm{C} / \mathrm{min}$ decomposition $+\mathrm{TPR}+\mathrm{TPD}$ \\
\hline \hline BET area & $171.0\left(\mathrm{~m}^{2} / \mathrm{g}\right)$ \\
\hline
\end{tabular}

\begin{tabular}{||c|c|c|c|c|c|c||}
\hline $\begin{array}{c}\mathrm{C}_{N_{2}} \\
(\%)\end{array}$ & $\mathrm{P} / \mathrm{P}_{0}$ & $\begin{array}{c}\mathrm{A}_{\text {ads }} \\
\text { (counts) }\end{array}$ & $\begin{array}{c}\mathrm{A}_{d e s} \\
\text { (counts) }\end{array}$ & $\begin{array}{c}\mathrm{V}_{\text {cal }} \\
(\mathrm{mL})\end{array}$ & $\begin{array}{c}\mathrm{A}_{\text {cal }} \\
\text { (counts) }\end{array}$ & $1 /\left(\mathrm{X}\left(\mathrm{P} / \mathrm{P}_{0}-1\right)\right)$ \\
\hline 28.8 & 0.284 & 1185 & 1146 & 1.5 & 1278 & 254 \\
18.7 & 0.185 & 729 & 727 & 1.5 & 872 & 156 \\
13.7 & 0.134 & 507 & 501 & 1.5 & 668 & 138 \\
\hline
\end{tabular}


$\underline{\text { Run 10-8 ATTM } / \mathrm{Al}_{2} \mathrm{O}_{3}, \text { BET Area Measurement }}$

\begin{tabular}{||l|l||}
\hline Date & $9 / 5 / 94$ \\
\hline Catalyst Weight & $0.0215 \mathrm{~g}$ \\
\hline Pretreatment & $10^{\circ} \mathrm{C} / \mathrm{min}$ decomposition $+\mathrm{TPR}+\mathrm{TPD}$ \\
\hline \hline BET area & $171.7\left(\mathrm{~m}^{2} / \mathrm{g}\right)$ \\
\hline
\end{tabular}

\begin{tabular}{||c|c|c|c|c|c|c||}
\hline $\begin{array}{c}\mathrm{C}_{N_{2}} \\
(\%)\end{array}$ & $\mathrm{P} / \mathrm{P}_{0}$ & $\begin{array}{c}\mathrm{A}_{a d s} \\
\text { (counts) }\end{array}$ & $\begin{array}{c}\mathrm{A}_{\text {des }} \\
\text { (counts) }\end{array}$ & $\begin{array}{c}\mathrm{V}_{c a l} \\
(\mathrm{~mL})\end{array}$ & $\begin{array}{c}\mathrm{A}_{c a l} \\
\text { (counts) }\end{array}$ & $1 /\left(\mathrm{X}\left(\mathrm{P} / \mathrm{P}_{0}-1\right)\right)$ \\
\hline 0.137 & 0.135 & 324 & 314 & 1.0 & 336 & 143.7 \\
0.187 & 0.183 & 527 & 466 & 1.0 & 452 & 186.8 \\
0.233 & 0.228 & 617 & 609 & 1.0 & 566 & 236.2 \\
0.301 & 0.295 & 829 & 890 & 1.0 & 718 & 292.0 \\
\hline
\end{tabular}

